\title{
Isoflavonas não melhoram e estrógenos pioram a aterosclerose induzida por dieta em camundongos deficientes para receptor de LDL (LDLr+/-) e transgênicos para a expressão da proteína de transferência de colesterol esterificado humana (CETPh+/-)
}

\section{Leiko Asakura}

Tese apresentada ao Programa de Pós-Graduação em Saúde Pública para obtenção do Título de Doutor em Saúde Pública

Área de Concentração: Nutrição Orientador: Prof. Dr. Eder C.R. Quintão

São Paulo

2005

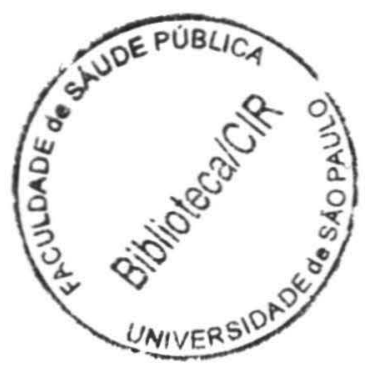




$$
45925 / 2005 \text { doe }
$$

Autorizo exclusivamente para fins acadêmicos e científicos, a reprodução total ou parcial desta tese, por processos fotocopiadores. Ao usá-lo, cite a fonte. Assinatura: Levpio Cpmuno Data: 
Asakura, L. Isoflavonas não melhoram e estrógenos pioram a aterosclerose induzida por dieta em camundongos deficientes para receptor de LDL (LDLr+/-) e transgênicos para a expressão da proteína de transferência de colesterol esterificado humana (CETP). São Paulo; 2005. [Tese de Doutorado - Faculdade de Saúde Pública da USP].

\section{ADENDO}

\section{Determinação da concentração plasmática de isoflavonas}

Para este ensaio foram acompanhados 30 animais, separados em três grupos: Iso High $(n=10)$, Iso Low $(n=10)$ e Controle $(n=10)$. Ao final de 10 semanas de consumo das respectivas dietas os animais foram sacrificados ao mesmo tempo, três horas após o fim do ciclo escuro do Biotério, em um intervalo de 40 minutos, a fim de se evitar uma grande variação de tempo pós-alimentar entre os animais. As amostras foram imediatamente centrifugadas em centrífuga refrigerada a $4^{\circ} \mathrm{C}, 1000 \mathrm{~g}$, por 15 minutos (Sorval, modelo RT 6000 B, Du Pont Company, Newton, CT, EUA) e o plasma congelado a $-70^{\circ} \mathrm{C}$ até a determinação da concentração de isoflavonas. A concentração plasmática de isoflavonas se eleva a partir de 30 minutos após a alimentação e atinge o pico em cinco horas (BINGHAM et al., 1998).

\section{Preparação das amostras}

Incubaram-se $250 \mu \mathrm{L}$ de plasma, $500 \mu \mathrm{L}$ de acetato de amônio $0,2 \mathrm{M}, \mathrm{pH} 4,6 \mathrm{e}$ $12,5 \mu \mathrm{L}$ de glicuronidase-sulfatase (4,2 unidades/mL, Sigma S-9751) com Biocianina $(7,5 \mu \mathrm{L})$ como padrão interno para uma concentração final de $20 \mu \mathrm{M}$, a $37^{\circ} \mathrm{C}$, overnight. As mini-colunas (Varian-Bond Elut LRC C18 - $200 \mathrm{mg} / 10 \mathrm{~mL}$, ref. 12113024) foram lavadas previamente com $1 \mathrm{~mL}$ de etanol a $90 \%$, seguido de $5 \mathrm{~mL}$ de água destilada gelada. Após o período de incubação das amostras, a solução resultante foi aplicada à mini-coluna para extração em fase sólida com água destilada gelada (4 $\mathrm{mL}$ ), sendo descartado o líquido resultante. As isoflavonas foram eluídas em etanol a 
$90 \%$ (1,5 mL) e a solução foi recolhida em tubos limpos. O extrato purificado foi seco em corrente de nitrogênio e o resíduo foi ressuspendido em $250 \mu \mathrm{L}$ de etanol a $90 \%$. A solução resultante foi filtrada em filtro de poro de $0,22 \mu \mathrm{m}$ e uma alíquota de $50 \mu \mathrm{L}$ foi analisada por HPLC.

Todas as análises de isoflavonas foram realizadas por HPLC, utilizando o cromatógrafo Shimadzu CBM-10A e o Software Class LC10. Utilizou-se coluna de fase reversa Hypersil ODS $5 \mu \mathrm{m}(250 \times$ x 4,6 mm, Supelco, Co) com fluxo da fase móvel de $0,8 \mathrm{~mL} / \mathrm{min}$. Utilizou-se gradiente linear composto por: A, ácido acético em água (10:90, v:v); B, metanol-acetonitrila-diclorometano (10:5:1, v:v:v); B em A (em volume) a $5 \%$ por 5 minutos, de $5 \%$ a $45 \%$ em 5 minutos, de $45 \%$ a $70 \%$ em 6 minutos e de $70 \%$ a 5\% em 3 minutos (Franke et al, 1998). Os padrões de genisteína, genistina, daidzeína, daizina e equol ram adquiridos da Endofine Chemical Co., EUA. As curvas de calibração, realizadas com estes padrões, foram utilizadas para a quantificação das diferentes isoflavonas presentes no plasma e na ração. A absorbância das isoflavonas foi monitorada em $262 \mathrm{~nm}$ e a do equol, em $280 \mathrm{~nm}$. As isoflavonas foram identificadas pelo tempo de retenção e pelo espectro.

\section{RESULTADOS}

A concentração plasmática de genisteína foi maior no grupo Iso High, quando comparado ao grupo Iso Low. Não houve diferença na concentração de daidzeína e de equol. Não se detectou qualquer isoflavona nos animais do grupo Controle. Excetuando-se os animais incluídos na Tabela 1, nos demais não se detectaram as isoflavonas pesquisadas.

Tabela 1. Concentração plasmática de isoflavonas $(\mu \mathrm{Mol} / \mathrm{L})$

\begin{tabular}{l|c|c|c}
\hline & Iso High (7) & Iso Low & Controle (10) \\
\hline daidzeína & $4,9 \pm 1,4$ & $2,9 \pm 0,5(10)$ & ND \\
\hline genisteína & $7,0 \pm 4,6 *$ & $2,7 \pm 0,4(9)$ & ND \\
\hline equol & $2,7 \pm 0,5$ & $0,3 \pm 0,9(3)$ & ND \\
\hline
\end{tabular}

* Comparação estatística: Iso High x Iso Low, Mann-Whitney, p<0.002 ND: não detectado 


\section{REFERÊNCIAS BIBLIOGRÁFICAS:}

A referência citada na página 40 , parágrafo $5^{\circ}$. (WEN et al. 2000) é a que segue abaixo, e que não foi devidamente posta nas Referências Bibliográficas.

Wen Y, Doyle MCT, Cooke T, Feeley J. Effect of menopause on low-density lipoprotein oxidation: is ostrogen an important determinant? Maturitas 2000;34:233-8.

\section{ERRATA:}

\subsection{Detecção de anticorpos anti- LDL oxidada (ox-LDL) e anti-ApoB-D}

A presença de anticorpos anti a partícula de LDL e anti um epítopo de apoBLP derivado de LDL oxidada (ApoB-D) foi mensurado pelo método de ELISA (BOSCHCOV et al., 2000). A ApoB-D é formada por um peptídeo de 22 aminoácidos oriundo de uma região da ApoB-100 não acessível à tripsina (BOSCHCOV et al., 2000). Placas de microtitulação de poliestireno (Costar, Cambridge, MA, EUA) foram cobertas com $50 \mu \mathrm{L} /$ cavidade de OxLDL humana $(7,5 \mu \mathrm{g} / \mathrm{mL}$, produzida por oxidação de $\mathrm{LDL}$ em presença de $20 \mathrm{mM} \mathrm{Cu} 2+$, durante $24 \mathrm{~h}$ ) ou com $50 \mu \mathrm{L}$ /cavidade de apoB-D $(0,1 \mu \mathrm{g} / \mathrm{mL})$ e mantida a $4^{\circ} \mathrm{C}$ por $12 \mathrm{~h}$. Após lavagem com PBS, as microplacas foram bloqueadas posteriormente com gelatina a 1\% (Invitrogen Co., Carlsbad, CA, EUA) em temperatura ambiente por 2 horas. As placas foram então lavadas duas vezes com PBS. Amostras de plasma $(50 \mu \mathrm{L}$, diluídas 1:100) foram adicionadas às placas e incubadas por 2 horas em temperatura ambiente. Após este período, as placas foram lavadas com PBS contendo Tween a $0,05 \%$ e adicionou-se conjugado peroxidase de cabra anti-IgG de camundongo (50 $\mu \mathrm{L}, 1: 15.000$, em PBS) (Pharmigen, San Diego, CA, EUA). Após nova lavagem, adicionaram-se $75 \mu \mathrm{L}$ de 3,3',5,5'-tetrametil-benzidina (TMB) (250mg em 50mL de DMSO) em tampão citrato, $\mathrm{pH} 5$,5. A reação foi interrompida pela adição de $25 \mu \mathrm{L}$ de $\mathrm{H}_{2} \mathrm{SO}_{4} 2 \mathrm{~N}$. Os resultados foram avaliados por leitura espectrofométrica a $450 \mathrm{~nm}$ de comprimento de onda em aparelho Multiskan MCC/340P, modelo 2.20 (Labsystems, Finlândia). 
Este trabalho foi realizado no Laboratório de Lípides (LIM 10) da Faculdade de Medicina da Universidade de São Paulo 


\section{AGRADECIMENTOS}

Ao Dr. Eder C.R. Quintão, estimado e admirado ORIENTADOR (com todas as letras maiúsculas mesmo!).

À Dra. Edna R. Nakandakare, chefe do Laboratório de Lípides (LIM 10), por permitir a realização deste trabalho e pelas valiosas contribuições, sempre no momento certo.

Às Dras. Patrícia M. Cazita, Valéria S. Nunes, Márcia D.T. Carvalho e Lila M. Harada, pela colaboração, pelas idéias e pelas conversas.

A Senária M. Eguti, pela companhia e pelos cafezinhos, que ajudaram bastante.

Aos colegas do LIM 10, porque uma pessoa não é uma ilha.

À Profa. Dra. Helena O.F. Coutinho e aos colegas Alessandro G. Salerno, Andréa C. Casqueiro e Jairo A. Berti, do Departamento de Fisiologia e Biofísica do Instituto de Biologia da Universidade Estadual de Campinas, pela importante e fundamental colaboração na realização deste trabalho.

À Prof ${ }^{a}$. Dr ${ }^{2}$. Diana Helena de B. Pozzi, ao Pedro A.F. Neto e ao Vicente L. Silva, pelo cuidado e atenção dispensados aos animais utilizados neste trabalho.

À Prof ${ }^{\mathrm{a}}$. Dr ${ }^{\mathrm{a}}$. Élia T.E.G. Caldini, a Nilsa Regina Damaceno Rodrigues, a Milena Coutinho da Motta e ao Daniel F.J. Ketelhuth, pela colaboração e apoio técnico.

À Profa. Dra. Consuelo J. Rodrigues, pelas análises histológicas dos úteros.

À Profa. Dra. Dulcinéia S.P. Abdalla, a Isabela R.O. Pereira e ao Maurício Santos, pela colaboração com a utilização do HPLC.

Aos colegas da FSP-USP, À FSP, em especial à Biblioteca, que é maravilhosa!

À Solae Company, pela doação da proteína de soja e das dietas.

À Diretoria Executiva dos Laboratórios de Investigação Médica da FMUSP, à Fundação Faculdade de Medicina e ao Biotério Central da FMUSP.

À FAPESP (processo 01/00994-9).

A todos que, direta ou indiretamente me ajudaram a realizar este trabalho.

Ao Carlo Yuji e ao Ivan. 


\section{RESUMO}

Asakura, L. Isoflavonas não melhoram e estrógenos pioram a aterosclerose induzida por dieta em camundongos deficientes para receptor de LDL (LDLr+/-) e transgênicos para a expressão da proteína de transferência de colesterol esterificado humana (CETP). São Paulo; 2005. [Tese de Doutorado - Faculdade de Saúde Pública da USP].

Objetivos. Por terem estrutura química semelhante as isoflavonas e os estrógenos podem influenciar o desenvolvimento da aterosclerose experimental, hipótese investigada em camundongos fêmeas expressando parcialmente receptores para LDL e proteína de transferência de colesterol esterificado (CETP). Métodos. Os animais foram ooforectomizados quando completaram oito semanas de vida e então submetidos à dieta aterogênica rica (\% por peso) em gordura (21) e colesterol $(0,2)$ por 19 semanas, desenvolvendo hipercolesterolemia moderada com perfil de lipoproteínas no plasma semelhante ao do ser humano. Em seguida, foram separados em quatro grupos experimentais: $E E(n=29)$, que receberam reposição de $17 \beta$-etinil-estradiol $(6 \mu \mathrm{g} / \mathrm{d})$ por meio de implante subcutâneo de pellet; Iso Low $(n=25)$, em cuja dieta foram adicionados $27,2 \mathrm{mg} / 100 \mathrm{~g}$ de isoflavonas; Iso High $(\mathrm{n}=28)$, cuja dieta continha $53,5 \mathrm{mg} / 100 \mathrm{~g}$ de isoflavonas; e Controle $(\mathrm{n}=28)$, recebendo apenas a dieta aterogênica. A dieta dos grupos EE e Controle continham apenas $0,01 \mathrm{mg} / 100 \mathrm{~g}$ de isoflavonas. Resultados. A despeito de o grupo EE ter apresentado menor concentração (mg/dL) de colesterol não ligado à HDL (n-HDL-C) $(84 \pm 8)$ quando comparado ao Iso Low $(95 \pm$ 6), mas, sem diferir dos demais, apresentou maior área $\left(\mu \mathrm{m}^{2} \times 10^{3}\right)$ de lesão aterosclerótica na raiz da aorta $(22,0 \pm 19,5)$, quando comparado ao Iso High $(7,4 \pm 6,4)$, ao Iso Low $(12,3 \pm 9,9)$ e ao Controle $(10,7 \pm 12,8)$. Estes três últimos não diferiram entre si. Após reunir os dados dos animais tratados com isoflavonas, a média da área de lesão $(9,9 \pm 8,6)$ persistiu menor, quando comparado ao grupo $\mathrm{EE}$, mas sem diferir do grupo Controle. Utilizando a mediana $(8,1)$ da área de lesão do grupo Controle como referência, o percentual da distribuição de animais com lesões acima deste valor foi 
significativamente diferente, nesta ordem: EE $>$ Iso Low $>$ Iso High. Por tanto, o tratamento com 17ß-etinil-estradiol resultou em maior proporção de animais com lesões maiores e o Iso High com menor proporção. A ação pró-aterogênica do EE deve estar relacionada à titulação de auto-anticorpos no plasma (média da densidade óptica a $450 \mathrm{~nm})$ tanto contra ox-LDL, que foi superior no grupo $\mathrm{EE}(0,86 \pm 0,23)$ do que no Controle apenas $(0,62 \pm 0,15)$, como contra ApoB-D (fração oxidada da LDL), que foi maior $(0,84 \pm 0,18)$ do que em Iso Low $(0,68 \pm 0,06)$, Iso High $(0,67 \pm 0,14)$ e Contole $(0,61 \pm 0,14)$. Embora o grupo EE não tenha sido investigado, experimentos adicionais utilizando o grupo Controle como referência (100\%), a captação por macrófagos de peritônio de camundongo de LDL humana acetilada marcada com $1 \alpha, 2 \alpha,(\mathrm{n})-\left[{ }^{3} \mathrm{H}\right]-$ colesteril oleoil éter $\left.\left({ }^{3} \mathrm{H}\right] \mathrm{COE}\right)$ foi menor no Iso High $(68 \%)$ do que no Iso Low $(85 \%)$ e do que no Controle. A remoção por HDL humana de $\left[4-{ }^{14} \mathrm{C}\right]$ colesterol de macrófagos enriquecidos com LDL marcada com $\left[4-{ }^{14} \mathrm{C}\right]$-colesteril oleato $\left(\left[{ }^{14} \mathrm{C}\right]\right.$-CE foi maior no Iso High (150\%) do que no Iso Low (99\%) e no Controle. Conclusões. Concluímos que as isoflavonas não foram eficientes para diminuir a aterosclerose experimental a despeito de mecanismos celulares antiaterogênicos quanto ao metabolismo de colesterol, talvez pelo fato de não interferirem no estado de oxidação das LDL in vivo, enquanto que este estado pró-oxidante pode estar ligado à aterogenicidade conferida pelo $17 \beta$-etinilestradiol.

Descritores: Isoflavonas. Estrógeno. Dieta. Camundongo. Aterosclerose. CETP 


\section{SUMMARY}

Asakura, L. Isoflavonas não melhoram e estrógenos pioram a aterosclerose induzida por dieta em camundongos deficientes para receptor de LDL (LDLr+/-) e transgênicos para a expressão da proteína de transferência de colesterol esterificado humana (CETP). [ Isoflavones do not improve and estrogens worsen diet induced atherosclerosis on mice LDL receptor deficient ( $\mathrm{LDLr}+/-)$ and transgenic for human cholesteryl ester transfer protein (CETPh+/-)]. São Paulo (BR); 2005. [PhD Thesis - Faculdade de Saúde Pública da Uiversidade de São Paulo, Brazil].

Objective. Because of their structural similarities isoflavones and estrogens may to the same extent influence the development of experimental atherosclerosis, an hypothesis investigated in female mice partially expressing genes for LDL receptors and cholesteryl ester transfer protein (CETP). Methods. Mice were ooforectomized at eight weeks of age and thereafter submitted to a fat/cholesterol rich diet for nineteen weeks eliciting moderate hypercholesterolemia and a lipoprotein profile similar that of humans and separated in four experimental groups: subcutaneous pellet graft of $17 \beta$-ethinyl-estradiol (EE - $6 \mu \mathrm{g} / \mathrm{d}, \mathrm{n}=29$ ); diet added mixtures of low dose (Iso Low- $27.2 \mathrm{mg} / 100 \mathrm{~g}, \mathrm{n}=25$ ), or high dose of isoflavone mixtures (Iso High $-53.5 \mathrm{mg} / 100 \mathrm{~g}, \mathrm{n}=28$ ); and the atherogenic diet alone as a Control group $(n=28)$. Results. After sacrifice it was shown that in spite of the lower non-HDL-C plasma concentration (mean $\mathrm{mg} / \mathrm{dL}$ ) reached by the EE group (84 \pm 8$)$, when compared to the Iso Low group $(95 \pm 6)$, although not differing from the other groups, EE aortic root lesion area (mean $\left.\mu \mathrm{m}^{2} \times 10^{3}\right)(22.0 \pm 19.5)$ was greater than that of Iso High $(7.4 \pm 6.4)$, from that of the Iso Low $(12.3 \pm 9.9)$ and the Control groups $(10.7 \pm 12.8)$, whereas the latter did not differ from both isoflavone treated groups. After pooling all isoflavone treated animals, their mean aortic lesion area $(9.9 \pm 8.6)$ remained lower than that of EE, not differing from that of the Control group. In addition, the percent distribution of the number of animals with larger lesion area in reference to the aortic fat storage median area value of the Controls (8.1) was significantly different, as follow: EE>Iso Low>Iso High. Therefore, $17 \beta$-ethinyl-estradiol elicited the largest and 
IsoHigh the lowest proportion of animals with large lesion areas. This $17 \beta$-ethinylestradiol unfavorable effect might be ascribed to high autoantibodies titers against both the plasma ox-LDL (measured by optical density at $450 \mathrm{~nm}$ ) that were 0.86 in EE as compared to 0.61 in Controls, as well as against apoB-D (an oxidized fraction of LDL) that were 0.84 in EE as compared to 0.68 in Iso Low, 0.67 in Iso High, and 0.61 in Controls. In additional experiments with Control mice as the reference value (100\%), in vitro mouse peritoneal uptake of donor human $1 \alpha, 2 \alpha,(\mathrm{n})-\left[{ }^{3} \mathrm{H}\right]$-cholesteryl oleyl ether acetylated LDL was low in Iso High (68\%), which was also lower than in Iso Low $(85 \%)$. Furthermore, the in vitro percent removal by donor human HDL of [4$\left.{ }^{14} \mathrm{C}\right]$ cholesterol from macrophages previously enriched with human $\left[4-{ }^{14} \mathrm{C}\right]$-cholesteryl oleate acetylated LDL was enhanced in Iso High $(150 \%)$, that was also greater than in Iso Low (99\%). Conclusions. Therefore, in spite of their antiatherogenic actions regarding the metabolism of cholesterol in macrophages shown in vitro, isoflavones failed to prevent against the fat fed induced atherosclerosis. It contrasts with the proatherogenic state of $17 \beta$-ethinyl-estradiol likely attributed to a pro-oxidant condition in vivo.

Descriptors: Isoflavones. Estrogen. Diet. Mice. Atherosclerosis. CETP. 


\section{LISTA DE ABREVIATURAS}

ApoA: apolipoproteína A

ApoB-D: apolipoproteína B-D

ApoE: apolipoproteína $\mathrm{E}$

ApoLP: apolipoproteína

CE: colesterol esterificado

$\mathrm{CEE}$ : estrógeno eqüino conjugado

CETP: cholesteryl ester tranfer protein - proteína de transferência de colesterol esterificado

CL: colesterol livre

EDTA: ácido etilenodiaminotetracético

FPLC: fast protein liquid chromatography - cromatografia líquida

HDL: high density lipoprotein - lipoproteína de baixa densidade

HPLC: high performance liquid chromatography - cromatografia líquida de alta eficiência

LCAT: lecitina colesteril:acil transferase

LDL: low density lipoprotein - lipoproteína de baixa densidade

LDLr: receptor de LDL

LLH: lipoproteína lipase hepática

LLP: lipoproteína lipase periférica

LLT: lipoproteina lipase total

LP: lipoproteínas

MPA: acetato de medroxiprogesterona

n-HDL-C: non-HDL-C - colesterol não ligado a HDL

QM: quilomícrons

RNAm: ácido ribonucléico mensageiro

TAG: triacilgliceróis

TLC: thin layer chromatography - cromatografia de camada delgada

TRH: terapia de reposição hormonal

VLDL: very low density lipoprotein - lipoproteína de muito baixa densidade 


\section{ÍNDICE}

1 INTRODUÇÃO 1

2 OBJETIVOS 6

2.1 Objetivo geral 6

2.2 Objetivos específicos 6

3 MÉTODOS 7

3.1 Protocolo experimental 7

3.2 Protocolo alimentar 9

3.3 Materiais 9

3.4 Matrizes dos camundongos 11

3.5 Geração dos animais para utilização no experimento 11

3.6 Criação e cuidados 11

$\begin{array}{lll}3.7 & \text { Cirurgia } & 12\end{array}$

3.8 Implantação do pellet de 17ß-etinil estradiol $\quad 12$

3.9 Análise da citologia vaginal $\quad 12$

3.10 Determinação da concentração de estrogênio no plasma 13

3.11 Sacrifício dos camundongos e coleta das amostras 13

$\begin{array}{ll}3.12 \text { Separação das lipoproteínas } & 14\end{array}$

3.13 Marcação das lipoproteínas 15

3.14 Determinação da atividade plasmática de CETP 15

$\begin{array}{ll}3.15 \text { Determinação da atividade enzimática da } & 16\end{array}$ lecitina:colesterol acil transferase (LCAT)

3.16 Determinação da atividade enzimática das lipoproteína-lipases 17

3.17 Análise do perfil de lipoproteínas por cromatografia 19 líquida (FPLC)

3.18 Peso uterino e análise histológica dos úteros 19

3.19 Análise das lesões ateroscleróticas 20

3.20 Detecção de anticorpos anti-LDL oxidada (ox-LDL) 21 e anti-ApoB-D

3.21 Cultura de macrófagos de peritônio de camundongos 22 
3.22 Quantificação do RNAm da CETP no fígado 25

4 ANÁLISE ESTATÍSTICA $\quad 27$

5 RESULTADOS 28

5.1 Separação das lipoproteínas por FPLC 28

5.2 Concentração plasmática de lípides e lipoproteínas 29

$\begin{array}{lll}5.3 & \text { Peso corporal dos camundongos e consumo } & 30\end{array}$ das respectivas dietas

5.4 Atividade plasmática da CETP e expressão d RNAm no fígado 30

5.5 Peso uterino e análise histológica dos úteros 32

5.6 Concentração plasmática de estrogênio 33

5.7 Área de lesão aterosclerótica 34

5.8 Anticorpos anti-LDL oxidada (ox-LDL) e anti-ApoB-D 35

5.9 Captação e remoção de colesterol 36

6 DISCUSSÃO $\quad 37$

7 CONCLUSÕES 44

8 REFERÊNCIAS BIBLIOGRÁFICAS 45

ANEXOS

Anexo 1. Composição da dieta padrão comercial $\quad$ A1

Anexo 2. Conteúdo de isoflavonas totais e livres $\quad$ A2

Anexo 3. Caracterização e duração do ciclo estral A3

Anexo 4. Citologia vaginal $\quad$ A4

Anexo 5. Análise macroscópica dos úteros $\quad$ A5

Anexo 6. Análise histológica dos úteros $\quad$ A6

$\begin{array}{ll}\text { Anexo 7. Áreas de lesão aterosclerótica } & \text { A7 }\end{array}$

Anexo 8. Resumo de trabalhos com animais e aterosclerose A8 experimental 


\section{INTRODUÇÃO}

A associação entre dietas ricas em soja e a baixa incidência de doenças cardiovasculares (ADLERCREUTZ e MAZUR, 1997) e de câncer (YUAN et al., 1995; SARKAR e LI, 2003), a melhora dos sintomas do climatério (ALBERTAZZI et al., 1998; NAMS, 2004), a supressão da reabsorção óssea (HORIUCHI et al., 2000) e a diminuição da colesterolemia em seres humanos (ANDERSON et al., 1995; ZHUO et al., 2004) atraíram a atenção para a soja.

A soja é rica em isoflavonas (as mais abundantes são genisteína e daidzeína), cuja ação biológica é semelhante aos estrogênios, razão pela qual são chamadas de fitoestrogênios (BINGHAM et al., 1998).

As isoflavonas são polifenóis encontrados quase que exclusivamente na soja, geralmente conjugados a uma molécula de açúcar na forma de $\beta$-glucosídeos.

As formas conjugadas das isoflavonas (principalmente genistina e daidzina) são hidrolisadas pelas glucosidases da flora intestinal, liberando às formas agliconas (genisteína e daidzeína). Estas formas livres, bem como seus metabólitos são absorvidos diretamente e liberados na circulação sangüínea; no fígado, as formas livres são conjugadas com o ácido glucurônico e excretadas na bile percorrendo a circulação enterohepática. Não mais que $30 \%$ das isoflavonas ingeridas são absorvidas e desta quantidade até $25 \%$ são excretadas na urina (TURNER et al., 2003).

A terapia com antibióticos diminui a excreção dos metabólitos, revelando a grande importância da flora intestinal (BOWEY et al., 2003). Por razões desconhecidas, cerca de $50 \%$ da população adulta não excreta equol na urina, mesmo quando consumindo diariamente uma dieta rica em soja (SETCHELL et al., 2002). O equol, o principal metabólito da daidzeína, tem uma ação estrogênica maior que a do seu precursor (TURNER et al., 2003).

A meta-análise realizada por ANDERSON et al. (1995) aponta para as isoflavonas como responsáveis pela ação hipocolesterolemiante da soja. Os efeitos das isoflavonas sobre as concentrações lipídicas em humanos são bem variáveis. A redução da concentração plasmática de LDL-C (colesterol de LDL - low density lipoprotein) pode chegar a 10\%, a de colesterol total (CT), 6,5\% (ZHUO et al., 2004) 
e a de triacilglicerol (TAG), 12,4\% (WANG et al., 2004), sem alteração significativa em HDL-C (colesterol de HDL - high density lipoprotein). Em humanos estas variações não são dose-dependente (WEGGEMANS e TRAUTWEIN, 2003).

É possível que esta ação hipocolesterolemiante seja devido ao aumento da concentração de RNA-mensageiro para receptor de LDL como visto por BAUM et al. (1998) em células mononucleares em mulheres hipercolesterolêmicas pósmenopausa alimentadas com soja, bem como à diminuição da secreção de apolipoproteína B (apoB) e da síntese celular de colesterol, de acordo com BORRADAILE et al. (2002) no estudo de cultura com células HepG2 de hepatoma humano.

Em um estudo com macacas (CLARKSON et al., 2001) e um outro com camundongos (KIRK et al., 1998), o consumo de dietas contendo proteina de soja resultou em redução da colesterolemia, o que pode explicar a diminuição das áreas de lesão aterosclerótica encontrada.

Já outro estudo com camundongos (NI et al., 1998) e com coelhos (YAMAKOSHI et al., 2000), também alimentados com proteína de soja, apesar de não se ter visto redução dos lípides plasmáticos, as áreas de lesão aterosclerótica foram menores quando comparadas ao grupo controle. Isto se deveu possivelmente à inibição da migração e da proliferação de células precursoras de células espumosas, fato verificado in vitro (SHIMOKADO et al., 1994), além de inibição da ativação (MURPHY et al., 1993) e da agregação plaquetária (ASAHI et al., 1992).

Um estudo in vitro (FOTSIS et al., 1993) mostra que a genisteína inibe a proliferação de células endoteliais, obtidas de veia umbilical humana, por diminuir a atividade do PA (Plasminogen Activator) e do PAI-1 (Plasminogen Activator Inhibitor 1) desta forma inibindo o crescimento tumoral pela angiogênese. Sabe-se que este último processo é crítico na formação do ateroma.

Observou-se também ativação da expressão gênica de apolipoproteína A-I (apoA-I) pela genisteína, verificada em células HepG2 (LAMON-FAVA, 2000). Isto é importante pelo fato de a apoA-I fazer parte da estrutura das partículas de HDL, as quais tem ação reconhecidamente anti-aterogênica.

Também está descrita a ação antioxidante das isoflavonas esterificadas incorporadas às partículas de LDL de humanos saudáveis, resultando em 
prolongamento do lag time, isto é, do tempo que a lipoproteina leva para iniciar a oxidação provocada in vitro por cobre (MENG et al., 1999a) e menor geração de anticorpos anti-LDL oxidada (ox-LDL) (DAMASCENO et al., 2000); esta ação antioxidante diminui em LDL de humanos após a retirada do suplemento à base de soja da dieta, quando comparada ao período de duas semanas da suplementação (TIKKANEN et al., 1998). No entanto, não se sabe se há transferência de isoflavonas entre as lipoproteinas.

As isoflavonas apresentam uma estrutura química semelhante ao estrogênio e por isto bastante considerada como uma alternativa à terapia de reposição hormonal (TRH) convencional, isto é, estrógeno eqüino conjugado (CEE) mais acetato de medroxiprogesterona (MPA), para mulheres após a menopausa. Esta perspectiva cresceu mais ainda após a publicação dos resultados dos estudos HERS - Heart and Estrogen/progestin Replacement Study (GRADY et al., 2002; HULLEY et al., 2002) e WHI - Women's Health Initiative (Writing Group for the WHI, 2002). No primeiro estudo, de prevenção secundária, não houve redução das taxas de eventos coronarianos e houve aumento das taxas de tromboembolismo venoso em usuárias de TRH; no segundo, de prevenção primária, houve aumento do risco para desenvolvimento de doenças cardiovasculares.

Uma das razões pelas quais as mulheres usam a TRH é o alívio dos sintomas do climatério e neste sentido as isoflavonas reduzem em até $20 \%$ a incidência das ondas de calor, quando comparadas ao placebo (MESSINA e HUGHES, 2003). Este resultado é consideravelmente baixo, se comparado à redução proporcionada pela TRH, que pode chegar a 77\% (MACLENNAN et al., 2001).

No estudo de CLARKSON et al. (2001), utilizando macacas ooforectomizadas, comparou-se o efeito das isoflavonas e do CEE sobre o desenvolvimento da aterosclerose nas artérias coronarianas e carótidas. Curiosamente, não houve diferença na concentração de CT e nem de colesterol não ligado às partículas de HDL (n-HDL-C) entre estes dois grupos, mas ambos foram menores que o grupo controle. A extensão das placas ateroscleróticas nas carótidas refletiu os lípides no plasma: não houve diferença entre CEE e isoflavonas e ambos foram menores que o grupo controle. No entanto, nas coronárias, não houve diferença entre isoflavonas e controle, e ambos foram maiores que CEE. 
LUCAS et al. (2003) também compararam os efeitos das isoflavonas e do $17 \beta$-estradiol na progressão da aterosclerose, mas utilizando hamster, em um modelo de pós-menopausa. Da mesma forma que no trabalho anterior, não houve diferença na concentração plasmática de CT ou de n-HDL-C e nem na freqüência de animais com lesão aterosclerótica entre os grupos tratados com estrógeno ou isoflavonas. A colesterolemia de ambos foi menor, quando comparado ao controle, mas a freqüência de animais com lesão não diferiu entre os três grupos.

Além destes fatores acima descritos, humanos, coelhos, macacos e hamsters têm CETP (cholesteryl ester transfer protein), que é uma proteína plasmática que transfere colesterol esterificado da HDL para lipoproteínas que contêm apoB (apoBLP): quilomícrons (QM) e VLDL (very low density lipoprotein) e seus remanescentes e LDL; estas últimas são então rapidamente removidas da circulação pelo fígado (TALL, 1984). Apesar da grande importância no transporte reverso de colesterol, seu papel no desenvolvimento da aterosclerose continua em questão (de GROOTH et al., 2004).

Camundongos naturalmente não expressam o gene da CETP. Nestes animais, as partículas de HDL são a principal forma de transporte de colesterol na circulação, o que os tornam relativamente resistentes ao desenvolvimento da aterosclerose. Ao expressarem CETP estes animais, quando submetidos à dieta aterogênica, se tornam mais susceptíveis ao desenvolvimento precoce da aterosclerose devido à elevação da concentração de LDL-C.

Embora esteja bem estabelecida a correlação inversa entre atividade de CETP e concentração plasmática de HDL-C, sua ação no processo de aterogênese ainda é controversa: estudos mostram que a CETP tem atividade anti-aterogênica (HAYEK et al., 1995; FOGER et al., 1999), como também pró-aterogênica (PLUMP et al., 1999; MAROTTI et al., 1993).

Mais recentemente, CAZITA et al. (2003) verificaram que camundongos fêmeas ooforectomizadas heterozigotas para a deficiência de receptores hepáticos de LDL, mas que expressam a CETP humana, desenvolveram menos aterosclerose, porém, tiveram colesterolemia menor, quando comparadas ao grupo sem CETP, sugerindo que esta proteína confere proteção na ausência de estrogênio. O primeiro 
grupo, quando submetido a uma dieta rica em gordura e colesterol, desenvolve hipercolesterolemia moderada, semelhante ao perfil lipídico humano.

Mulheres normolipidêmicas, comparadas aos homens, têm maior concentração de CETP (MARCEL et al., 1990) bem como as pré-menopausadas, comparadas às pós-menopausadas (ZHANG et al., 2001). Já em camundongos, tanto a ooforectomia (VADLAMUDI et al., 1998), quanto a administração de 17ß-etinil estradiol (ZUCKERMAN et al., 1999), não alteraram a atividade da CETP.

Sabe-se que os estrogênios, a CETP e a LCAT (lecithin:cholesterol acyltransferase) têm relevante influência no metabolismo de lípides e lipoproteínas: o 17ß-etinil-estradiol, após ser esterificado pela LCAT, é incorporado às partículas de HDL e transferido para as LDL por ação da CETP (HELISTEN et al., 2001), conferindo proteção a estas últimas contra a oxidação (MENG et al., 1999b).

A genisteína tem uma afinidade maior pelo receptor $\beta$ de estrogênio $(0,87$, comparado ao $17 \beta$-estradiol, utilizado como padrão, com valor de referência igual a 1) do que pelo receptor $\alpha(0,04$, comparado ao $17 \beta$-estradiol); a daidzeína apresenta uma afinidade bem mais baixa para ambos os receptores $\beta$ e $\alpha$, comparado ao $17 \beta$ estradiol - 0,005 e 0,001, respectivamente (KUIPER et al., 1998). Embora as isoflavonas tenham uma atividade estrogênica fraca, de 0,01 a 0,1\% (DEMONTY et al., 2003), os autores dos trabalhos citados sugerem que os resultados encontrados são decorrentes desta atividade.

As isoflavonas despertaram grande interesse por sua semelhança estrutural e funcional ao $17 \beta$-estradiol, sendo consideradas como uma possível alternativa à TRH em mulheres pós-menopausa, quer seja para aliviar os sintomas do climatério, como as ondas de calor, quer seja para prevenir o desenvolvimento de doenças crônicas prevalentes nesta fase, como a osteoporose, as doenças cardiovasculares e o câncer. Estamos longe de esclarecer por completo os respectivos mecanismos pelos quais as isoflavonas exercem seus efeitos no organismo humano.

Considerando estes aspectos, decidimos por comparar os efeitos da reposição via subcutânea do $17 \beta$-etinil estradiol e do consumo de dietas ricas em isoflavonas no perfil lipídico e na evolução das lesões ateroscleróticas em um modelo experimental de menopausa, contribuindo desta forma, para possibilitar a elucidação de alguns mecanismos de ação das isoflavonas. 


\section{OBJETIVOS}

\section{$2.1 \quad$ Objetivo geral}

Avaliar o perfil lipídico e investigar mecanismos envolvidos no desenvolvimento da lesão aterosclerótica em camundongos fêmeas ooforectomizadas, heterozigotas para a expressão da CETP e para a deficiência de receptores de LDL, consumindo dieta rica em gordura saturada e colesterol, com adição de proteína de soja contendo ou não isoflavonas, comparado à reposição de $17 \beta$-etinil-estradiol.

\subsection{Objetivos específicos}

- Determinar a atividade da CETP, da LCAT e das lipoproteínas-lipases hepática e periférica.

- Simultaneamente, investigar a captação de colesterol de LDL acetilada e na remoção de colesterol mediada pelas HDL em macrófagos de peritônio de camundongo.

- Quantificar os anticorpos anti-LDL oxidadas e anti-apoB-D.

- Avaliar a influência dos tipos de tratamento sobre a citologia e a histologia da ectocérvice.

- Medir a área de depósito de gordura na raiz da aorta. 


\section{METODOLOGIA}

\subsection{Protocolo experimental}

Foram estudados 110 camundongos fêmeas, heterozigotos para a deficiência de receptores hepáticos de LDL e para a expressão do gene da CETP, ooforectomizados para anular o efeito protetor dos estrogênios naturais, com oito semanas de vida, alimentadas com dieta rica em gordura, com ou sem adição de isoflavona e submetidos ou não à reposição estrogênica, por 19 semanas. A Figura 1 mostra resumidamente o protocolo, conforme descrito a seguir.

Inicialmente, como seleção, todos os animais em iguais condições de idade e peso, tiveram o perfil lipídico analisado, ou seja, foram realizadas dosagens bioquímicas para determinação da concentração de CT e TAG no plasma em jejum de 10 horas, além da quantificação da atividade exógena da CETP.

Às oito semanas de vida, quando atingem a maturidade sexual, os animais foram ooforectomizados e separados em quatro grupos experimentais: $E E(n=29)$, Iso Low ( $n=25)$, Iso High $(n=28)$ e Controle $(n=28)$. Três semanas após a ooforectomia foi avaliada a citologia vaginal dos animais e foram dosados os estrogênios para avaliação da eficácia das condutas aplicadas.

Durante o estudo foram realizadas medidas semanais de controle: consumo alimentar e peso corporal; o perfil lipídico foi avaliado antes e após as 19 semanas de tratamento.

Ao final de 19 semanas os animais foram sacrificados para a realização da análise histológica da lesão aterosclerótica na raiz da aorta, bem como para verificar o peso do útero e novamente foi avaliada a citologia vaginal dos animais e foram dosados os estrogênios. Foi colhido o fígado para quantificação do RNA-mensageiro (RNAm) da CETP. 

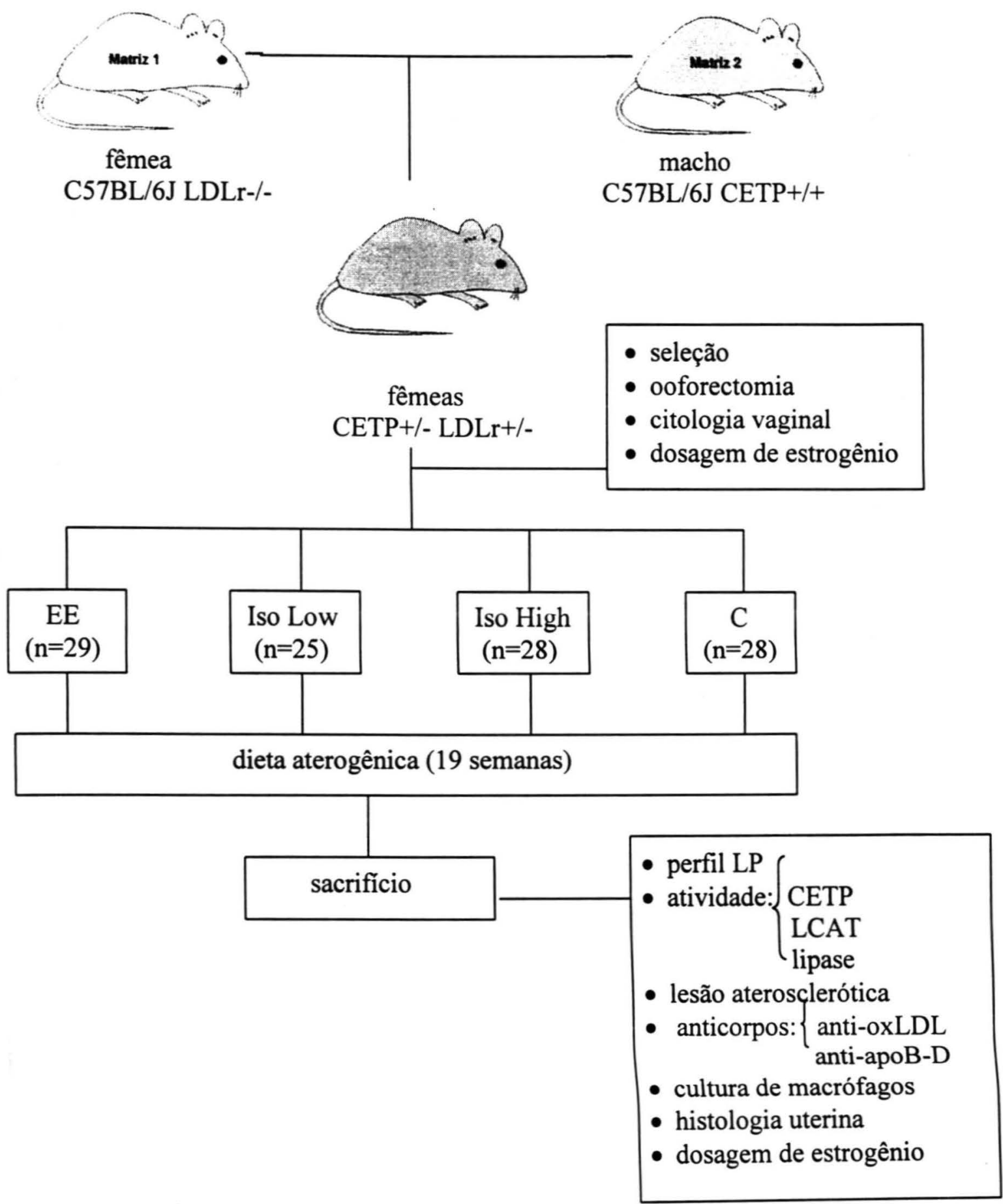

Figura 1. Protocolo experimental. 


\subsection{Protocolo alimentar}

A ração padrão comercial (Anexo 1) foi oferecida a partir do desmame até a $8^{\text {a }}$. semana de vida; em seguida, ofertou-se a dieta aterogênica, que serviu como controle e que teve o objetivo de provocar aterosclerose, até o final do experimento ( $27^{\mathrm{a}}$. semana de vida), num total de 19 semanas, tempo suficiente para se verificar alterações das concentrações de lípides (KIRK et al., 1998) e estimado para desenvolvimento da aterosclerose experimental (CAZITA et al., 2003).

A característica da dieta aterogênica ofertada aos quatro grupos experimentais é a quantidade de gordura saturada de leite $(21 \%)$ e de colesterol $(0,2 \%)$. A dieta ainda continha $44 \%$ de carboidrato (amido de milho) e $22 \%$ de proteína de soja. Como fonte de proteína de soja, na dieta do grupo Iso High foi adicionado o SuproSoy®, na dieta do grupo Iso Low, $50 \%$ de SuproSoy® e $50 \%$ de AWISP (alchool washed isolated soy protein - proteína de soja com reduzido teor de isoflavona por extração com álcool) e na dieta dos grupos C e EE, AWISP (Anexo 2).

Os animais foram separados em quatro grupos experimentais: grupo Controle (C), que recebeu dieta aterogênica; grupo Iso High, que recebeu dieta aterogênica com alto teor de isoflavonas livres $(53,5 \mathrm{mg} / 100 \mathrm{~g})$; grupo Iso Low, que recebeu dieta aterogênica com baixo teor de isoflavonas livres $(27,2 \mathrm{mg} / 100 \mathrm{~g})$ e grupo de reposição estrogênica (EE), que recebeu dieta aterogênica e reposição de estrogênio por meio de implante de pellet via subcutânea, com liberação diária de $6 \mu \mathrm{g}$.

A dieta dos grupos C e EE continha $0,01 \mathrm{mg} / 100 \mathrm{~g}$ de isoflavonas livres. Preconizaram-se duas doses de isoflavonas: alta (Iso High) e baixa (Iso Low) para saber se os possíveis efeitos são dose-dependente. A dose alta foi estabelecida considerando a quantidade utilizada por KIRK et al. (1998).

\subsection{Materiais}

A dieta comercial padrão Nuvilab CR1 foi adquirida da Nuvital Nutrientes Ltda. (Colombo, PR, Brasil) e o SuproSoy ${ }^{\circledR}$ e o AWISP, da Solae Company (St. 
Louis, MO, EUA) e acrescentados às dietas pela própria Harlan Teklad (Madison, WI, EUA).

Os reagentes, sais e solventes foram obtidos da Sigma-Aldrich Co. (St. Louis, MO, EUA) e da Merck S.A. Ind. Química (Rio de Janeiro, RJ, Brasil); o kit enzimático para determinação da concentração de CT, da Boehringer-Mannheim GmbH (Mannheim, Alemanha) e para TAG, da Merck KGaA (Darmstadt, Alemanha); a solução cintiladora Ultima Gold, da Packard (Meriden, CT, EUA); os filtros estéreis de 0,22, da Millipore (Belford, MA, EUA); os isótopos radioativos [4$\left.{ }^{14} \mathrm{C}\right]$-colesteril oleato (atividade específica de $45-60 \mathrm{mCi} / \mathrm{mmol}$ ), $\left[4-{ }^{14} \mathrm{C}\right]$-colesterol (atividade específica de $57 \mathrm{mCi} / \mathrm{mmol}$ ), e $\left[9,10{ }^{3} \mathrm{H}(\mathrm{N})\right]$-trioleína (atividade específica 26,8 Ci/mmol), da New England Nuclear - NEN - (Boston, MA, EUA); a sílica Gel G, da Merck KGaA (Darmstadt, Alemanha).

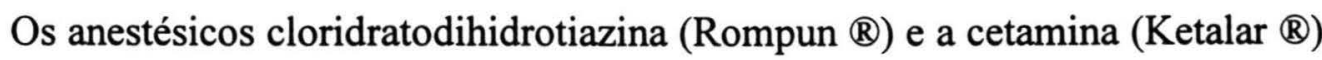
foram adquiridos da Bayer S.A., Brasil, e da Parke-Davis do Brasil, respectivamente.

Os pellets de $17 \beta$-etinil-estradiol com liberação diária de $6 \mu \mathrm{g} / \mathrm{d}$ foram adquiridos da Innovative Research of America (Toledo, OH, EUA) (MARSH et al, 1999) e o kit para dosagem de estradiol, da Cayman Chemical Co. (Ann Arbor, MI, EUA).

A coluna Superose 6 HR 10/30 utilizada para a separação de lipoproteínas foi adquirida da FPLC System, Pharmacia (Upsalla, Suécia).

Os corantes Oil red $O$, hematoxilina e Light Green foram adquiridos da Amresco Inc. (Solon, Ohio, EUA), o meio de inclusão TBS - Tissue Freezing Medium, da Triangle Biomedical Sciences, (Durham, NC, EUA) e a gelatina tipo A de pele suína, da Sigma-Aldrich Co. (St. Louis, MO, EUA).

O soro bovino fetal, o soro humano deficiente em lipoproteína, a albumina bovina livre de ácidos graxos e os meios de cultura DMEM (Dubelcco's Modified Eagles's Medium) e RPMI-1640 foram adquiridos da Sigma Chemical Co (St. Louis, MO, EUA); as placas estéreis para cultura de 24 cavidades, da Becton Dickinson Labware (Lincoln Park, NJ, EUA). 


\subsection{Matrizes dos camundongos}

Matriz 1: Camundongos machos C57BL/6J CETP+/+ obtidos a partir de cruzamento entre os animais heterozigotos. Esta linhagem, além de conter os elementos responsivos naturais do gene da CETP, possui padrão de expressão tecidual da proteína semelhante ao humano. Os camundongos heterozigotos são procedentes da Divisão de Medicina Molecular da Universidade de Columbia, NY, EUA, e foram gentilmente cedidos pela Profa. Dra. Helena C. F. Oliveira, da Universidade de Campinas - UNICAMP, com a anuência do Dr. Alan Tall.

Matriz 2: Camundongos fêmeas LDLr-/- (knock-out) para deficiência de receptores de LDL, adquiridos comercialmente do Jackson Laboratory (Bar Harbor, ME, EUA).

\subsection{Geração dos animais para utilização no experimento}

Foram selecionadas as fêmeas heterozigotas (CETP+/- LDL+/-) obtidas a partir do cruzamento das matrizes 1 e 2 .

Justifica-se o uso destes animais pelo fato de o perfil das lipoproteínas do plasma se aproximar ao encontrado nos seres humanos.

\subsection{Criação e cuidados}

Após o desmame ( $3^{\mathrm{a}}$. semana de vida), os camundongos foram alimentados com ração comercial padrão e água ad libitum por cinco semanas e mantidos em gaiolas plásticas (4 a 5 animais/gaiola), em ambiente com temperatura e umidade controladas, e ciclo de luz/escuro de 12 horas. Ao fim das cinco semanas de dieta com ração comercial padrão, os animais foram separados para a formação de grupos homogêneos, considerando idade e peso corporal. 
Semanalmente os animais foram pesados e o consumo das dietas foi verificado pela diferença de peso entre a quantidade de ração oferecida e as sobras pesadas na semana subseqüente, dividida pelo número de animais.

\subsection{Cirurgia}

Os camundongos foram submetidos à ooforectomia, previamente anestesiados por injeção intra-peritoneal de cloridratodihidrotiazina $(16 \mathrm{mg} / \mathrm{kg}$ peso) misturado à cetamina $(50 \mathrm{mg} / \mathrm{kg}$ peso $)$.

\subsection{Implantação do pellet de $17 \beta$-etinil-estradiol}

Os pellets contendo $0,5 \mathrm{mg}$ de $17 \beta$-etinil-estradiol, com liberação de $6 \mu \mathrm{g} / \mathrm{d}$, foram implantados por via subcutânea, conforme instruções da empresa fornecedora (Innovative Research of America, Toledo, OH, EUA). A implantação do pellet ocorreu após o acompanhamento do ciclo estral por meio da análise da citologia vaginal dos animais, realizada três semanas após a ooforectomia.

\subsection{Análise da citologia vaginal}

O sucesso da ooforectomia foi conferido analisando-se a citologia vaginal dos animais durante cinco dias consecutivos, três semanas após a cirurgia. Neste período, no mesmo horário, o material foi colhido por meio de introdução de uma ponteira descartável contendo solução físiológica, depositado em uma lâmina e corado com hematoxilina e Schorr.

A análise das lâminas dos animais revelou uma citologia atrófica, na qual há células parabasais e predominantemente células basais e não são vistas células superficiais. $\mathrm{Na}$ citologia as fases do ciclo estral dos camundongos (proestro, metaestro, estro, diestro e anestro) foram conferidas segundo a técnica de 
VANNUCCHI e SATZINGER (1997) (Anexos 3 e 4). Os animais efetivamente castrados apresentaram predomínio da fase diestro ou anestro (MONTES e LUQUE, 1988).

\subsection{Determinação da concentração de estrogênio no plasma}

As dosagens de estrogênio no plasma foram realizadas pelo método imunoenzimático e a leitura das amostras foi feita em espectrofotômetro em comprimento de onda entre 405 a $420 \mathrm{~nm}$, conforme instruções do fabricante (Cayman Chemical Co., Ann Arbor, MI, EUA). Este kit detecta concentrações superiores a $7,8 \mathrm{pg} / \mathrm{mL}$.

Este ensaio é baseado na competição entre o estradiol livre (específico), presente nas amostras de plasma, e o estradiol de coelho (não específico) pela ligação com o anticorpo monoclonal de camundongo.

Resumidamente, em uma placa com 96 cavidades revestidas com anticorpo monoclonal de camundongo, $50 \mu \mathrm{L}$ da amostra foram incubados com igual volume do traçador (estradiol ligado à acetilcolinesterase) e do estradiol de coelho por uma hora, em temperatura ambiente num agitador orbital. Depois deste período, as cavidades foram esvaziadas e lavadas exaustivamente com tampão. Após este procedimento, foram adicionados $200 \mu \mathrm{L}$ do reagente de Ellman, que tem o substrato para a acetilcolinesterase, a fim de se realizar uma reação de cor. Após 30 minutos, as amostras foram lidas em espectrofotômetro. A intensidade da cor é proporcional à quantidade do traçador ligado nas cavidades, a qual é inversamente proporcional à quantidade de estradiol livre presente nas mesmas cavidades durante a incubação.

\subsection{Sacrifício dos camundongos e coleta das amostras}

Ao fim do período estabelecido de 19 semanas, os animais foram mantidos em jejum de 12 horas e depois pesados e anestesiados por injeção de uma mistura de cloridratodihidrotiazina ( $32 \mathrm{mg} / \mathrm{kg}$ peso) com cetamina ( $100 \mathrm{mg} / \mathrm{kg}$ peso). 
O sangue foi coletado pela artéria braquial em tubos contendo EDTA como anticoagulante.

Os órgãos dos animais foram perfundidos pelo ventrículo esquerdo com solução fisiológica $(\mathrm{NaCl} 0,9 \%)$ gelada e, em seguida, com formalina a $10 \%$ para iniciar a fixação da aorta. O fígado de cada animal foi retirado, lavado com solução fisiológica, imediatamente congelado em nitrogênio líquido e armazenado a $-70^{\circ} \mathrm{C}$ para posterior quantificação do RNAm da CETP.

O coração e os ramos aórticos foram removidos e colocados em formalina a $10 \%$ durante pelos menos 48 horas até o seu processamento para determinação das áreas de lesão aterosclerótica.

$\mathrm{O}$ útero foi retirado desde o final das duas tubas uterinas até a vagina, inclusive, pesado e analisado histologicamente.

\subsection{Separação das lipoproteínas}

As lipoproteínas utilizadas para determinação da atividade da CETP e da LCAT, como também na cultura de macrófagos, foram obtidas a partir de pool de plasma de humanos doadores normolipidêmicos.

O sangue dos doadores foi coletado após jejum de 12 horas em tubos contendo EDTA a $10 \%(10 \mu \mathrm{L} / \mathrm{mL}$ sangue $)$ e imediatamente centrifugado em centrífuga refrigerada Sorval, Modelo RT 6000 B (Du Pont Company, Newton, CT, EUA) a $4^{\circ} \mathrm{C}$, a $1000 \mathrm{~g}$, por 15 minutos, para separação do plasma. Foram adicionados os conservantes benazimidina $2 \mathrm{mM}(5 \mu \mathrm{L} / \mathrm{mL})$, gentamicina com clorafenicol $15 \mathrm{mM}$ $(20 \mu \mathrm{L} / \mathrm{mL})$, fenilmetil sulfonil fluoreto (FMSF) $0,5 \mathrm{mM}(0,5 \mu \mathrm{L} / \mathrm{mL})$ e aprotinina $10 \mathrm{mg} / \mathrm{mL}(5 \mu \mathrm{L} / \mathrm{mL})$.

As lipoproteínas foram separadas por ultracentrifugação seqüencial (HAVEL et al, 1955), utilizando um rotor $50 \mathrm{Ti}$ em ultracentrífuga Beckman, modelo L-8 (Beckman Instruments, Palo Alto, CA, EUA). A densidade do plasma foi mantida a $1,006 \mathrm{~g} / \mathrm{mL}$ para a separação da fração de VLDL, obtida após ultracentrifugação de 12 horas, a $100.000 \times \mathrm{g}$ e a $4^{\circ} \mathrm{C}$; a densidade do infranadante foi ajustada com $\mathrm{KBr}$ sólido para 1,063 g/mL para obtenção da fração de LDL, após ultracentrifugação de 
20 horas, a $100.000 \times \mathrm{g}$ e a $4^{\circ} \mathrm{C}$; a densidade do infranadante foi ajustada para 1,21 $\mathrm{g} / \mathrm{mL}$ e utilizado para obtenção da HDL a ser radiomarcada com $\left[{ }^{14} \mathrm{C}\right]$-colesteril oleato.

\subsection{Marcação das lipoproteínas}

As partículas de LDL foram marcadas com $\left[4-{ }^{14} \mathrm{C}\right]$-colesteril oleato $\left(\left[{ }^{14} \mathrm{C}\right]-\right.$ CE) ou $1 \alpha, 2 \alpha,(n)-\left[{ }^{3} \mathrm{H}\right]$-colesteril oleoil éter $\left(\left[{ }^{3} \mathrm{H}\right] \mathrm{COE}\right)$ para utilização na cultura de macrófagos e as partículas de HDL foram marcadas com $\left[4-{ }^{14} \mathrm{C}\right]$-colesteril oleato $\left(\left[{ }^{14} \mathrm{C}\right]-\mathrm{CE}\right)$ para determinação da atividade de CETP nos testes de triagem dos animais e nas análises após os tratamentos.

Para marcação isotópica das partículas de LDL foram utilizados $6,7 \mu \mathrm{Ci}$ de $\left[{ }^{14} \mathrm{C}\right]-\mathrm{CE}$ ou $10 \mu \mathrm{Ci}$ de $\left[{ }^{3} \mathrm{H}\right] \mathrm{COE}$ por $\mathrm{mL}$ de infranadante $(\mathrm{d}=1,006 \mathrm{~g} / \mathrm{mL})$ e $0,2 \mu \mathrm{Ci}$ de $\left[{ }^{14} \mathrm{C}\right]$-CE por $\mathrm{mL}$ de HDL em infranadante $(\mathrm{d}>1,21 \mathrm{~g} / \mathrm{mL})$.

$\mathrm{O}$ isótopo dissolvido em tolueno foi seco sob fluxo de nitrogênio, rediluído em $100 \mu \mathrm{L}$ de etanol e adicionado gota-a-gota ao infranadante do plasma $\mathrm{d}>1,063$ $\mathrm{g} / \mathrm{mL}$, sob agitação lenta, durante cinco minutos. Esta mistura foi incubada em banho-maria com agitação a $37^{\circ} \mathrm{C}$ por 24 horas; após o período de incubação a densidade foi ajustada com $\mathrm{KBr}$ sólido para as respectivas frações de lipoproteínas e ultracentrifugada a $100.000 \times \mathrm{g}$ a $4^{\circ} \mathrm{C}$. As lipoproteínas radiomarcadas foram dialisadas exaustivamente contra tampão fosfato contendo 0,01\% de EDTA ( $\mathrm{pH} 7,4)$, filtradas com filtros Millipore estéreis de $0,22 \mu \mathrm{m}$, e determinada sua composição em CT, TAG e proteínas.

A LDL radioativa foi posteriormente acetilada com anidrido acético $(1,5 \mu \mathrm{L}$ vezes a massa de proteína da LDL), conforme descrito por BASU et al. (1976).

\subsection{Determinação da atividade plasmática de CETP}

A atividade da CETP foi determinada utilizando $50 \mu \mathrm{L}$ de ${ }^{14} \mathrm{C}-\mathrm{HDL}(40$ $\mathrm{mg} / \mathrm{dL}$ de CT) como partículas doadoras e $200 \mu \mathrm{L}$ de VLDL + LDL $(200 \mathrm{mg} / \mathrm{dL}$ de $\mathrm{CT}$ ) como aceptoras de colesterol éster, na presença de $10 \mu \mathrm{L}$ do plasma dos animais 
como fonte de CETP. Esta mistura foi incubada a $37^{\circ} \mathrm{C}$ durante duas horas. Após este periodo, foram adicionados $30 \mu \mathrm{L} / \mathrm{mL}$ de solução de sulfato de dextrana:cloreto de magnésio (1:1) e a mistura foi centrifugada a $1000 \times \mathrm{g}$ por 30 minutos com o objetivo de precipitar as apoB-LP; uma alíquota de $200 \mu \mathrm{L}$ do sobrenadante foi coletada e a ela adicionado $2,5 \mathrm{~mL}$ de solução cintiladora Ultima Gold e a radioatividade determinada em contador beta Beckman LS6000-TA (Beckman Instruments, Palo Alto, CA, EUA).

$\mathrm{O}$ cálculo da porcentagem de transferência de $\left[{ }^{14} \mathrm{C}\right]-\mathrm{CE}$ das frações de HDL para as apoB-LP foi feito segundo a expressão:

$\%$ transferência de $\left[{ }^{14} \mathrm{C}\right]-\mathrm{CE}=\left[1\right.$ - (contagem de radioatividade da amostra a $37^{\circ} \mathrm{C} /$ contagem da radioatividade do branco controle a $\left.\left.37^{\circ} \mathrm{C}\right)\right] \times 100$

\subsection{Determinação da atividade enzimática da lecitina:colesterol acil transferase (LCAT)}

A atividade da enzima lecitina:colesterol acil transferase (LCAT) foi medida com substratos endógenos, ou seja, o próprio plasma do animal (DOBIASOVA et al., 1992). Resumidamente, $20 \mu \mathrm{L}$ de plasma foram incubados com um pequeno disco de papel de filtro Whatman-1 contendo $0,08 \mu \mathrm{Ci}$ de $\left[4-{ }^{14} \mathrm{C}\right]$-colesterol livre, na presença de $80 \mu \mathrm{L}$ de tampão Tris $(\mathrm{pH}=7,4)$ a $4^{\circ} \mathrm{C}$ durante 24 horas. Após a difusão do isótopo para o meio, as amostras foram incubadas a $37^{\circ} \mathrm{C}$ por 30 minutos e posteriormente colocadas em banho de gelo para inibição da atividade da enzima. Uma alíquota de $10 \mu \mathrm{L}$ foi colocada em placa de sílica gel G para separar o colesterol livre (CL) do esterificado (CE) por cromatografia de camada delgada (TLC). As placas foram eluídas com uma mistura de hexano:éter etílico:ácido acético (v:v:v, 70:30:1), e reveladas com vapor de iodo. As respectivas bandas de CL e CE foram transferidas para frascos contendo $3 \mathrm{~mL}$ de solução cintiladora, agitadas e a radioatividade determinada em contador beta Beckman LS6000-TA (Beckman Instruments, Palo Alto, CA, EUA). 
O cálculo foi realizado conforme a seguinte expressão:

$\%$ de esterificação $=$ (contagem de radioatividade de $\mathrm{CE} /$ contagem de radioatividade de $\mathrm{CL}+\mathrm{CE}) \times 100$

\subsection{Determinação da atividade enzimática das lipoproteína-lipases}

A atividade da lipoproteína-lipase hepática (LLH) e a da total (LLT) foi determinada pela modificação do método de EHNHOLM et al. (1986) pela medida da quantidade de ácidos graxos livres liberados a partir de um substrato de trioleína marcado radioativamente na posição dos ácidos graxos. A atividade da lipoproteínalipase periférica (LLP) foi calculada pela diferença entre a atividade da LLT e a atividade da LLH.

Preparo do substrato:

Foram misturados $200 \mu \mathrm{L}(40 \mathrm{mg}$ ) de trioleína (em tolueno) e $50 \mu \mathrm{L}$ $\left(25 \mu \mathrm{Ci} / \mathrm{mL}\right.$ ) de ${ }^{3} \mathrm{H}$-trioleína (em tolueno/etanol). Os solventes foram secos sob fluxo de nitrogênio, ressuspensos com $0,6 \mathrm{~mL}$ de heptano e secos novamente. $O$ procedimento foi repetido duas vezes. À mistura foram adicionados $3 \mathrm{~mL}$ de goma arábica $5 \%$ e emulsificada com ultra-som (20-30 watts), em 8 ciclos de 30 segundos (240 segundos), em banho de gelo, em um sonicador Branson Cell Disruptor modelo 450 com ponta de titânio de $1 \mathrm{~cm}$ de diâmetro (Branson Ultrasonics Co. Dunbury, CT, EUA). Finalmente, foram adicionados $2 \mathrm{~mL}$ de solução de albumina livre de ácidos graxos a $10 \%$ e vigorosamente agitados.

Plasma pós-heparina:

As lipases localizam-se aderidas às paredes dos endotélios, não sendo encontradas na corrente sanguínea. Portanto, para medir a atividade no plasma é 
preciso liberá-las para a circulação, por meio de injeção subcutânea de 250 UI de heparina/kg de peso. Após 10 minutos, $50 \mu \mathrm{L}$ de sangue foram colhidos e centrifugados sob refrigeração $\left(4^{\circ} \mathrm{C}\right)$ e o plasma separado imediatamente.

Atividade da LLH:

A atividade da enzima LLH foi determinada por meio de incubação do plasma pós-heparina com o substrato de trioleína marcado com ${ }^{3} \mathrm{H}$-trioleína (o radioisótopo está ligado ao ácido graxo). A enzima hidrolisa a ligação glicerol-ácidos graxos. Os ácidos graxos livres foram extraídos e foi medida a radioatividade. A atividade da enzima foi inibida em meio com 2,0 $\mathrm{M}$ de $\mathrm{NaCl}$.

Em tubo de centrifugação de $1,5 \mathrm{~mL}$ foram colocados $44 \mu \mathrm{L}$ do substrato, 55 $\mu \mathrm{L}$ do tampão (0,2 M Tris- $\mathrm{HCl}: 2,0 \mathrm{M} \mathrm{NaCl}), \mathrm{pH} 8,5$ e $10 \mu \mathrm{L}$ de plasma pósheparina (como fonte da enzima). A seguir, os tubos foram incubados por 60 minutos em banho-maria a $37^{\circ} \mathrm{C}$.

Após a incubação, foram adicionados $715 \mu \mathrm{L}$ de metanol:clorofórmio:heptano (1,41:1,25:1) e $165 \mu \mathrm{L}$ de solução $0,14 \mathrm{M}$ de $\mathrm{K}_{2} \mathrm{CO}_{3}$ $/ \mathrm{H}_{3} \mathrm{BO}_{3}, \mathrm{pH} 10,5$. Os tubos foram agitados por 20 segundos e centrifugados por 30 minutos a $3000 \times \mathrm{g}$. Foram retirados $200 \mu \mathrm{L}$ do sobrenadante e colocados em um frasco de contagem com $3 \mathrm{~mL}$ de solução contadora Ultima Gold, na qual foi medida a radioatividade com solução cintiladora em contador beta Beckman LS6000TA.

Atividade da LLT:

A atividade LLT foi determinada por meio do mesmo método utilizado para a da LLH. Foi alterado apenas o tampão $0,2 \mathrm{M}$ Tris- $\mathrm{HCl}$ (pH 8,5), que não contém $\mathrm{NaCl}$.

Atividade da LLP:

A atividade da LLP foi determinada pela diferença entre a LLT e LLH. 
O cálculo é feito a partir da seguinte fórmula:

contagem da radioatividade da amostra - contagem da radioatividade do branco / 406DPM/nmol AGL x 2,5 x 100

\subsection{Análise do perfil das lipoproteínas por cromatografia líquida (FPLC)}

Alíquotas de pool de plasma de três animais de cada grupo foram injetadas numa coluna Superose 6 HR 10/30 (FPLC System, Pharmacia, Upsalla, Suécia). As lipoproteínas foram eluídas numa velocidade de $0,5 \mathrm{~mL} / \mathrm{min}$ com tampão Tris, $\mathrm{pH}$ 7,4. Após a eluição as 10 frações iniciais foram descartadas e as 30 frações seguintes de $0,5 \mathrm{~mL}$ foram coletadas e o colesterol determinado enzimaticamente em analisador automático bioquímico Cobas Mira (F. Hoffmann Roche, Basiléia, Suíça), utilizando kit comercial da Boehringer-Mannheim. A identificação dos picos correspondentes às frações VLDL, LDL e HDL foi determinada pela absorbância do CT.

\subsection{Peso uterino e análise histológica dos úteros}

Ao sacrifício, os úteros foram retirados em conjunto com as tubas uterinas e a vagina, sendo pesados em balança digital com capacidade de $1500 \mathrm{~g}$, com precisão de 0,05g (Denver Instruments Co., Denver, CO, EUA). A peça, então, seguiu para rotina histológica, sendo fixada em solução de formalina $10 \%$ em tampão fosfato e embebida em parafina. Os blocos de parafina contendo o tecido foram submetidos a cortes de $5 \mu \mathrm{m}$ de espessura e estes corados com hematoxilina e eosina e examinados sob microscópio de luz. Foram analisados os órgãos de 11 animais do grupo EE, oito do Iso Low, oito do Iso High e sete do Controle. 


\subsection{Análise das áreas de lesão aterosclerótica}

Compreende-se como área de lesão aterosclerótica a área de depósito de gordura.

O processamento e a coloração foram realizados de acordo com a técnica de PAIGEN et al., 1987. As áreas contendo lípides foram quantificadas conforme a técnica descrita por RUBIN et al., 1991.

Inicialmente, os corações foram mantidos em formalina a $10 \%$ por no mínimo 48 horas; posteriormente foram transferidos para uma cápsula, identificados e colocados sob água corrente durante pelo menos duas horas. Passado este período, estas cápsulas foram incubadas em banho-maria a $40^{\circ} \mathrm{C}$ por duas horas em gelatina tipo A obtida de pele suína (Type A-Porcine Skin, Sigma-Aldrich Co.) a 5\% e, em seguida, em gelatina a $10 \%$ por mais duas horas e, finalmente, em gelatina a $25 \%$ por 12 horas. Posteriormente, os corações foram colocados sob refrigeração por três horas, até atingirem a consistência de um bloco de gelatina e mantidos a $4^{\circ} \mathrm{C}$ em formalina a $10 \%$.

O processamento dos cortes foi iniciado pelos ventrículos, os quais foram seccionados entre o ápice e a base num plano paralelo a uma linha definida pelas pontas laterais dos átrios.

Os corações foram embebidos em TBS - Tissue Freezing Medium (Triangle Biomedical Sciences, Durham, NC, EUA) e colocados na câmara de congelamento do criostato Microtomo HM 505 E (Micron, Tokyo, Japão). Os cortes tiveram início a partir da porção distal do coração. Após a identificação da raiz aórtica, onde os três folhetos valvulares são visíveis, oito cortes seriados de $10 \mu \mathrm{m}$ foram coletados em lâminas de microscopia cobertas com uma fina camada de gelatina. A distância percorrida do seguimento da aorta foi de $480 \mu \mathrm{m}$, ou seja, até onde as válvulas não eram mais visualizada, totalizando seis lâminas por animal.

As lâminas foram coradas com Oil Red $O$ (corante de gordura) e contracoradas com hematoxilina (corante dos núcleos celulares) e Light Green (corante das demais organelas e do citoplasma). A imagem das áreas de depósito de gordura foi capturada por câmara Kohler e pelo microscópio Leica DMLS (McBain Instruments, Chatsworth, CA, EUA) e quantificada utilizando-se o software Image-ProPlus, 
versão 3.0 para Windows (Media Cybernetics, Newburyport, MA, EUA). A área foi calculada para cada animal e subseqüentemente calculada a média para cada grupo.

É importante ressaltar que o investigador responsável por estas análises desconhece os tratamentos aos quais os animais foram submetidos.

\subsection{Detecção de anticorpos anti- LDL oxidada (ox-LDL) e anti-ApoB-D}

A presença de anticorpos anti a partícula de LDL e anti um epítopo de apoBLP derivado de LDL oxidada (ApoB-D) foi mensurado pelo método de ELISA (BOSCHCOV et al., 2000). A ApoB-D é formada por um peptídeo de 22 aminoácidos oriundo de uma região da ApoB-100 não acessível à tripsina (BOSCHCOV et al., 2000). Placas de microtitulação de poliestireno (Costar, Cambridge, MA, EUA) foram cobertas com $50 \mu \mathrm{L} /$ cavidade de OxLDL humana $(7,5 \mu \mathrm{g} / \mathrm{mL}$, produzida por oxidação de LDL em presença de $20 \mathrm{mM} \mathrm{Cu} 2+$, durante $24 \mathrm{~h})$ ou com $50 \mu \mathrm{L} /$ cavidade de apoB-D $(0,1 \mu \mathrm{g} / \mathrm{mL})$ e mantida a $4^{\circ} \mathrm{C}$ por $12 \mathrm{~h}$. Após lavagem com PBS, as microplacas foram bloqueadas posteriormente com gelatina a 1\% (Invitrogen Co., Carlsbad, CA, EUA) em temperatura ambiente. As placas foram então lavadas duas vezes com PBS. Amostras de plasma $(20 \mu \mathrm{L}$, diluídas 1:100) foram adicionadas às placas e incubadas por 2 horas em temperatura ambiente. Após este período, as placas foram lavadas com PBS contendo Tween a 0,05\% e adicionou-se conjugado peroxidase de cabra anti-IgG de camundongo (1:15.000, em PBS) (Pharmigen, San Diego, CA, EUA). Após nova lavagem, adicionaram-se $50 \mu \mathrm{L}$ de 3,3',5,5'-tetrametil-benzidina (TMB) (250mg em 50mL de DMSO) em tampão citrato, pH 5,5. A reação foi interrompida pela adição de $\mathrm{H}_{2} \mathrm{SO}_{4} 2 \mathrm{~N}$. Os resultados foram avaliados por leitura espectrofométrica a $450 \mathrm{~nm}$ de comprimento de onda em aparelho Multiskan MCC/340P, modelo 2.20 (Labsystems, Finlândia).

Para detectar a concentração de IgG total do plasma algumas placas não foram tratadas com LDL oxidada ou ApoB-D mas incubadas com amostras individuais de plasma, diluídas 20.000 vezes em tampão carbonato, por 12 horas a $4^{\circ} \mathrm{C}$ e bloqueadas com $5 \%$ de leite desnatado. 
A expressão da concentração de anticorpos pela média da densidade óptica foi realizada utilizando a seguinte fórmula:

anticorpos $=$ D.O. amostra - D.O. branco / D.O. IgG total

\subsection{Cultura de macrófagos de peritônio de camundongos}

Este ensaio foi realizado segundo a técnica de HARA e YOKOYAMA, 1991.

Obtenção dos macrófagos de peritônio de camundongo:

Após 19 semanas de dieta aterogênica os animais foram anestesiados por injeção de uma mistura de cloridratodihidrotiazina (32 $\mathrm{mg} / \mathrm{kg}$ peso) com cetamina (100 mg/kg peso) e exanguinados pela artéria braquial. Os macrófagos foram obtidos do peritônio após injeção de $6 \mathrm{~mL}$ de tampão fosfato $\left(\mathrm{NaCl}\right.$ 0,8\%, $\mathrm{Na}_{2} \mathrm{HPO}_{4} \quad 0,07 \%$, $\mathrm{KCl} 0,02 \%$ e $\mathrm{KH}_{2} \mathrm{PO}_{4}$ 0,04\%), sem EDTA, estéril, pH 7,4. As células em tampão fosfato foram retiradas com auxílio de uma seringa estéril e o líquido colocado num tubo cônico estéril e centrifugado a $500 \times \mathrm{g}, 4^{\circ} \mathrm{C}$, por 2-3 minutos. Desprezou-se o sobrenadante e diluiu-se o botão celular com RPMI 1640 contendo $20 \%$ de soro bovino fetal (SBF) e os seguintes antibióticos: $100 \mathrm{U} / \mathrm{mL}$ de penicilina e $0,1 \mathrm{mg} / \mathrm{mL}$ de estreptomicina (L-glutamina-penicillin-streptomycin, Sigma Chemical Co. St. Louis, MO, EUA). Foi feito um pool de células dos animais de cada grupo (Iso Low, $\mathrm{n}=6$; Iso High, $\mathrm{n}=8$; Controle, $\mathrm{n}=8$ ) chegando a uma concentração final de $3 \times 10^{6}$ células $/ \mathrm{mL}$. As células $(0,5 \mathrm{~mL})$ foram colocadas em seis placas de cultura com 24 cavidades e incubadas por 2 horas numa estufa com atmosfera de $5 \%$ de $\mathrm{CO}_{2}$ para adesão dos macrófagos nas placas. $\mathrm{O}$ controle das incubações consistiu de cavidades sem células, somente com o meio RPMIa (com antibiótico) e $20 \%$ de soro bovino 
fetal (SBF). Após a incubação, as placas foram lavadas 2 vezes com o meio RPMIa sem SBF.

Retirada de colesterol das células pela HDL:

Os macrófagos aderidos às placas foram enriquecidos com LDL humana acetilada e radioativamente marcada com $\left(\left[{ }^{14} \mathrm{C}\right]-\mathrm{CE}-\mathrm{LDL}\right)$, segundo o método de BROWN e GOLDSTEIN (1983). As placas foram incubadas com RPMIa 1640 contendo $2 \mathrm{mg} / \mathrm{mL}$ de albumina bovina sérica (ABS) isenta de ácidos graxos, na presença de $50 \mu \mathrm{g}$ de proteína/mL de ${ }^{14} \mathrm{C}-\mathrm{CE}-\mathrm{LDL}$ acetilada por $24 \mathrm{~h}$, numa estufa a $37^{\circ} \mathrm{C}$ com atmosfera de $5 \%$ de $\mathrm{CO}_{2}$. Após a incubação, o meio foi descartado e as placas lavadas com DMEM contendo penicilina $\mathrm{G}$ potássica $(100 \mathrm{U} / \mathrm{mL})$, sulfato de estreptomicina $(100 \mathrm{U} / \mathrm{mL})$ e fungizona $(2,5(\mathrm{~g} / \mathrm{mL})$ (DMEMa). Em seguida, os macrófagos foram incubados com DMEMa (com os antibióticos) contendo $2 \mathrm{mg} / \mathrm{mL}$ de (ABS) na presença de HDL humana (100 $\mu \mathrm{g}$ de proteína de HDL/mL) como aceptora do colesterol celular, por um período de 6 horas. O controle das placas com HDL consistiu de cavidades com e sem células, incubadas com albumina. Após esse período de incubação, todo o meio de cada cavidade foi coletado cuidadosamente para contagem da radiação captada pelas HDL (radiação total no meio). Em seguida, as placas foram lavadas com solução fisiológica, e as células descoladas com 200 $\mu \mathrm{L} /$ cavidade de $\mathrm{NaOH} 0,2 \mathrm{~N}$ durante $5 \mathrm{~h}$ sob agitação lenta, para contagem da radiação que permaneceu dentro da célula. Algumas placas foram incubadas somente com ${ }^{14} \mathrm{C}$-LDL acetilada, para medir a radiação total incorporada pelos macrófagos, e outras para determinar a proteína celular pelo método de LOWRY et al. (1951).

O cálculo é feito a partir da seguinte fórmula:

$\%$ de $\left[{ }^{14} \mathrm{C}\right]-\mathrm{CE}$ retirado $=$ radioatividade do meio $/$ (radioatividade do meio + radioatividade de dentro célula) $\mathrm{x} 100$ 
O resultado final da retirada de colesterol celular, expresso como mediana da porcentagem, foi obtido pela diferença entre a porcentagem da retirada de colesterol nas incubações feitas com a HDL e as feitas nos controles contendo apenas albumina.

Captação de colesteril oleoil éter $\left({ }^{3} \mathrm{H}-\mathrm{COE}\right)$ de LDL acetilada pelos macrófagos:

Os macrófagos aderidos nas placas foram incubados com o meio de RPMIa 1640 contendo $10 \%$ de soro humano deficiente em LP $(3,5 \mathrm{mg}$ proteína $/ \mathrm{mL})$ na presença de $50 \mu \mathrm{g}$ de proteína/mL de ${ }^{14} \mathrm{C}$-CE-LDL humana acetilada por $6 \mathrm{~h}$ numa estufa a $37^{\circ} \mathrm{C}$ com atmosfera de $5 \%$ de $\mathrm{CO}_{2}$. Após a incubação, o meio foi descartado e as placas lavadas com solução fisiológica e as células descoladas com 200 $\mu \mathrm{L} /$ cavidade de $\mathrm{NaOH} 0,2 \mathrm{~N}$ durante cinco horas sob agitação lenta, para contagem da radiação que permaneceu dentro da célula. Algumas placas contendo macrófagos aderidos foram utilizadas para determinação da proteína celular (LOWRY et al., 1951) e para controle da radiação oferecida $\left({ }^{14} \mathrm{C}-\mathrm{CE}-\mathrm{LDL}\right.$ acetilada) aos macrófagos.

O cálculo é feito a partir da seguinte fórmula:

\% captação $\left[{ }^{3} \mathrm{H}\right]-\mathrm{COE}=$ (radiação de dentro da célula / radiação total adicionada à cavidade) $\times 100 / \mathrm{mg}$ proteína celular

O resultado final da captação celular de colesterol foi expresso como mediana da porcentagem / mg de proteína celular. 


\subsection{QUANTIFICAÇÃO DO RNAm DA CETP NO FÍGADO}

Extração de RNA:

O RNA total foi extraído do fígado segundo a descrição metodológica do fabricante utilizando o reagente Trizol (Invitrogen, EUA). A pureza e a quantificação dos RNA totais foram determinadas espectrofotometricamente considerando: DO $260 \mathrm{~nm} / 280 \mathrm{~nm}>1,7$ e 1,0 unidade DO $260 \mathrm{~nm}=40 \mu \mathrm{g} / \mathrm{mL}$, respectivamente. Após a quantificação, foi realizada uma eletroforese em gel de agarose a 1,2\% corado com brometo de etídio em Tris-borato $89 \mathrm{mM}$ e EDTA $2 \mathrm{mM}$, com $1 \mu \mathrm{g}$ de RNA total de cada amostra, para confirmar a integridade dos RNA e comprovar a homogeneidade das respectivas densidades das subunidades $28 \mathrm{~s}$ e $18 \mathrm{~s}$. As amostras foram armazenadas a $-70^{\circ} \mathrm{C}$ até serem utilizadas para o RT-PCR.

Obtenção de cDNA a partir de RNA total para a RT-PCR:

O cDNA foi obtido a partir de $1 \mu \mathrm{g}$ de RNA total por transcrição reversa, utilizando $150 \mathrm{ng}$ de amplímeros aleatórios (Random Primers, Invitrogen, EUA), dNTPs $10 \mathrm{mM}(1 \mu \mathrm{L})$ e $200 \mathrm{U}$ de transcriptase reversa (Superscript II RNAse $\mathrm{H}^{-}$, Invitrogen, EUA), em um volume final de $20 \mu \mathrm{L}$, incubado a $42^{\circ} \mathrm{C}$ por $50 \mathrm{~min}$, seguidos de 15 min a $70^{\circ} \mathrm{C}$ a fim de inativar a enzima. O produto de transcrição foi armazenado a $-20^{\circ} \mathrm{C}$ até o momento de uso.

A RT-PCR semiquantitativa foi realizada utilizando $3 \mu \mathrm{L}$ do produto de transcrição reversa (cDNA) das amostras que foram co-amplificadas na presença de 7,5 pmol de amplímeros direto e reverso de padrão GAPDH (394 pb, GenBank no. M32599, 5'-CTG CAT CCA CTG GTG CTG-3' e 5'- AGG GTT TCT TAC TCC TTG GAG G-3' e 15 pmol da CETP (225 pb, GenBank no. NM_000078, 5'-CCA AGG TGA TCC AGA CCG-3' e 5'-TGG TGT AGC CAT ACT TCA GGG-3') em tampão de PCR ( $\mathrm{KCl} 50$ mM, MgCl 1,5 mM, Tris- $\mathrm{HCl} 20$ mM, pH 8,3), $200 \mathrm{mM}$ de cada dNTP, 5\% de DMSO, e 2U de Taq DNA polimerase, em volume final de 50 $\mu \mathrm{L}$. 
Após uma desnaturação inicial a $94^{\circ} \mathrm{C}$ por $4 \mathrm{~min}$, seguiu-se a amplificação em 28 ciclos de 1 min de desnaturação a $94^{\circ} \mathrm{C}, 1$ min e $30 \mathrm{~s}$ de associação a $54^{\circ} \mathrm{C}$ e 2 min de extensão a $72^{\circ} \mathrm{C}$. Ao final dos ciclos foi acrescida extensão de 10 min a $72^{\circ} \mathrm{C}$. Uma alíquota de $10 \mu \mathrm{L}$ do produto de RT-PCR foi submetido a eletroforese em gel horizontal de agarose $2 \%$ contendo brometo de etídio para visualizar as respectivas densidades. $\mathrm{O}$ gel foi fotografado num sistema de documentação de gel, e a análise da intensidade das bandas correspondentes foi feita pelo programa da Alpha Imager TM 1220 (Alpha Innotec Co, EUA) em microcomputador. A quantificação baseou-se na comparação entre a intensidade das 2 bandas correspondentes à amostra e ao padrão interno GAPDH, e expresso como э porcentagem em relação ao controle $100 \%$. 


\section{ANÁLISE ESTATÍSTICA}

Para análise estatística foi utilizado o programa GraphPad Prism, versão 3.0 para Windows, produzido pela GraphPad Software Inc. (San Diego, CA, EUA). A comparação entre os grupos tratados e controle foi realizada pelo teste ANOVA, seguida de pós-teste adequados, com nível de significância $p<0,05$. Para comparação da distribuição da freqüência de animais com áreas de lesão arterial utilizou-se o teste do $\chi^{2}$. 


\section{RESULTADOS}

\subsection{Separação das lipoproteínas por FPLC e concentração de lípides e} lipoproteínas

A Figura 2 mostra o perfil de lipoproteínas obtido por FPLC da absorbância de colesterol $(\mathrm{CT})$ de pool $(\mathrm{n}=3)$ de plasma de camundongo C57BL/6 e a Figura 3 mostra o perfil de lipoproteínas de camundongo CETP+/- LDLr+/-.

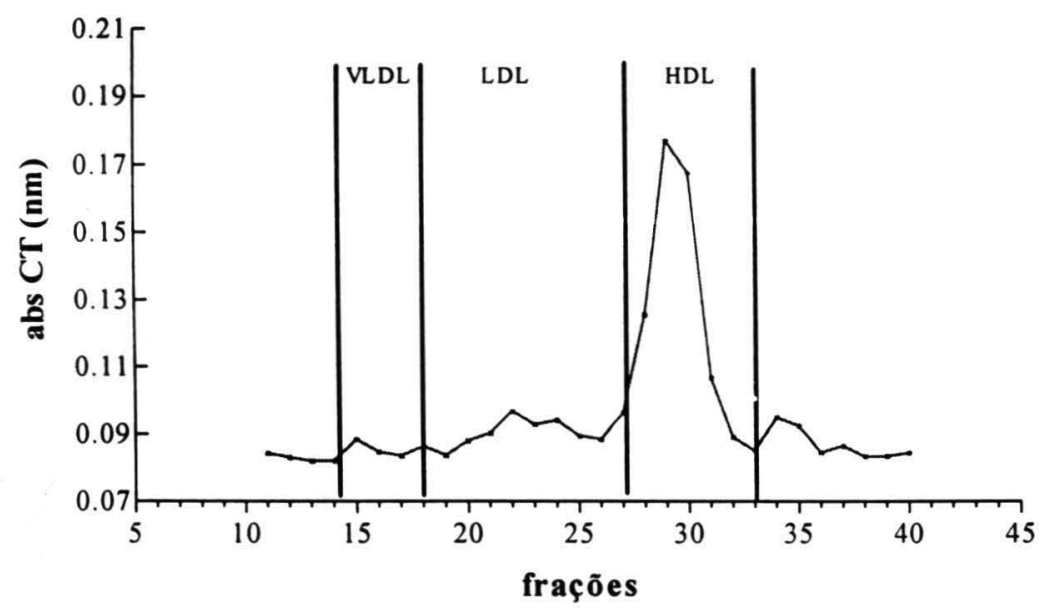

Figura 2. Perfil de lipoproteínas de camundongo C57BL/6.

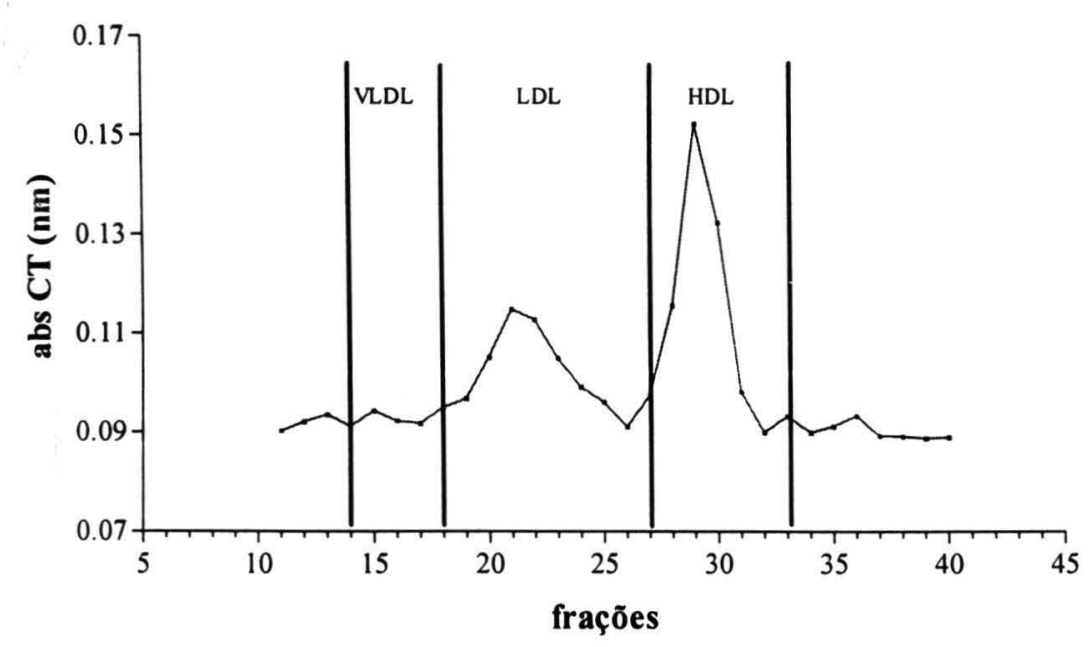

Figura 3. Perfil de lipoproteínas de camundongo CETP+/- LDLr+/-. 


\subsection{Concentração plasmática de lípides e lipoproteínas}

O perfil das LP e a concentração dos lípides plasmáticos no período basal dos grupos foram determinados 2 semanas após a cirurgia de ooforectomia. As concentrações de colesterol total (CT) e de triacilgliceróis (TAG) não foram diferentes entre os grupos experimentais. Ao final do período estabelecido de 19 semanas, foram realizadas as dosagens plasmáticas de lípides e determinado o perfil de LP. A concentração de colesterol não ligado às partículas de HDL (n-HDL-C) foi menor no grupo EE, comparado ao grupo Iso Low e a concentração de TAG foi maior neste grupo, comparado ao demais (Tabela 1).

Tabela 1. Concentração plasmática de lípides e de lipoproteínas $(\mathrm{mg} / \mathrm{dL})$ dos animais nos periodos basal (B) e final (F).

\begin{tabular}{ll|l|l|l|l|l}
\hline & & \multicolumn{1}{c|}{ EE } & \multicolumn{1}{c}{ Iso Low } & \multicolumn{1}{c}{ Iso High } & \multicolumn{1}{c}{ Controle } & \\
\hline CT & (B) & $94 \pm 14(29)$ & $93 \pm 13(21)$ & $86 \pm 10(25)$ & $87 \pm 10(26)$ & NS \\
& (F) & $141 \pm 34(13)$ & $155 \pm 29$ & $155 \pm 31$ & $151 \pm 31$ & NS \\
\hline VLDL-C (B) & $26 \pm 1$ & $25 \pm 0,1$ & $27 \pm 1$ & $27 \pm 0,2$ & NS \\
& (F) & $37 \pm 3$ & $43 \pm 4$ & $42 \pm 5$ & $42 \pm 5$ & NS \\
\hline LDL-C & (B) & $33 \pm 0,1$ & $32 \pm 0,4$ & $28 \pm 1$ & $29 \pm 0,3$ & NS \\
& (F) & $48 \pm 6$ & $52 \pm 3$ & $51 \pm 4$ & $51 \pm 3$ & NS \\
\hline HDL-C & (B) & $35 \pm 1$ & $36 \pm 1$ & $31 \pm 1$ & $31 \pm 1$ & NS \\
& (F) & $56 \pm 8$ & $60 \pm 6$ & $61 \pm 5$ & $59 \pm 6$ & $\mathrm{NS}$ \\
\hline n-HDL-C (B) & $59 \pm 1$ & $56 \pm 1$ & $55 \pm 1$ & $56 \pm 1$ & $\mathrm{NS}$ \\
& (F) & $84 \pm 8^{*}$ & $95 \pm 6^{\#}$ & $94 \pm 5^{*}$ & $92 \pm 6^{*}$ & $\mathrm{p}<0,05$ \\
\hline TAG & (B) & $67 \pm 20(17)$ & $101 \pm 40(14)$ & $114 \pm 81(17)$ & $115 \pm 57(16)$ & $\mathrm{NS}$ \\
& (F) & $54 \pm 20^{*}(12)$ & $97 \pm 68^{*}(16)$ & $60 \pm 23^{*}(22)$ & $66 \pm 25^{*}(22)$ & $\mathrm{p}<0,05$ \\
\hline
\end{tabular}

Os valores representam a média \pm desvio padrão.

Os valores entre parênteses indicam o número de animais.

As frações de lipoproteínas foram obtidas após fracionamento do pool plasmático (n=3) por FPLC. n-HDL-C (colesterol não ligado à fração HDL), obtido a partir da diferença entre CT e HDL-C.

Comparação estatística: CT e TAG, ANOVA, seguida de pós-teste de múltipla comparação de Newman-Keuls, $\mathrm{p}<0,05$ para símbolos diferentes; colesterol das frações (VLDL, LDL, HDL) e n-HDL-C, Kruskal-Wallis, seguido de pós-teste de múltipla comparação de Dunns, $\mathrm{p}<0,05$ para símbolos diferentes.

NS: não significativo 


\subsection{Peso corporal dos camundongos e consumo das respectivas dietas}

O peso corporal e o consumo das dietas foram acompanhados semanalmente. A média de peso dos animais dos grupos experimentais não foi diferente no período basal, mas diferiu ao final do estudo (Tabela 2), enquanto que a média do consumo (g) das dietas pelos respectivos grupos não variou (basal, 3,2 $\pm 0,6$; final, $2,9 \pm 0,8$ ).

Tabela 2. Média de peso corporal (g) período basal e final.

\begin{tabular}{|c|c|c|c|c|c|}
\hline Peso (g) & $\mathrm{EE}$ & Iso Low (25) & Iso High & Controle & \\
\hline basal & $\begin{array}{l}19,7 \pm 2,5 \\
(29)\end{array}$ & $18,8 \pm 2,9^{\mathrm{a}}$ & $20,0 \pm 3,2(27)^{a}$ & $19,8 \pm 4,1(27)^{\mathrm{a}}$ & NS \\
\hline \multirow[t]{2}{*}{ final } & $\begin{array}{l}24,2 \pm 2,2 \\
(14)^{*}\end{array}$ & $\begin{array}{l}27,4 \pm 3,9 \\
\text { * \# b }\end{array}$ & $\begin{array}{l}33,5 \pm 7,7 \\
(28) \& \mathbf{b}\end{array}$ & $\begin{array}{l}29,5 \pm 4,8 \\
(28){ }^{\# ~ b}\end{array}$ & $\begin{array}{l}\mathrm{p}<0,05 \\
\text { para } \\
\text { símbolos } \\
\text { diferentes }\end{array}$ \\
\hline & NS & $\begin{array}{l}\mathrm{p}<0,05 \text { para } \\
\text { letras diferentes }\end{array}$ & $\begin{array}{l}\mathrm{p}<0,05 \text { para letras } \\
\text { diferentes }\end{array}$ & $\begin{array}{l}p<0,05 \text { para letras } \\
\text { diferentes }\end{array}$ & \\
\hline
\end{tabular}

Os valores representam a média \pm desvio padrão. Os valores entre parênteses indicam o número de animais.

Comparação estatística: ANOVA, seguida de pós-teste de múltipla comparação de Newman-Keuls, $\mathrm{p}<0,05$ para símbolos e letras diferentes.

NS: não significativo.

\subsection{Atividade plasmática da CETP e expressão do RNAm no fígado}

Não houve diferença na atividade da CETP entre os grupos nos períodos basal e final (Tabela 3), mas houve diferença, quando comparados os períodos, em cada grupo e a expressão do RNAm da CETP foi maior no grupo EE, comparado aos demais. 
Tabela 3. Atividade da CETP (\%) nos períodos basal e final e expressão (\%) do RNAm hepático da CETP no período final.

\begin{tabular}{l|l|l|l|l|l}
\hline CETP & \multicolumn{1}{|c|}{ EE } & \multicolumn{1}{c|}{ Iso Low } & Iso High (25) & Controle & \\
\hline basal $^{\text {a }}$ & $\begin{array}{l}20,3 \pm 5,0 \\
(29)\end{array}$ & $\begin{array}{l}22,0 \pm 7,5 \\
(21)\end{array}$ & $\begin{array}{l}23,2 \pm 7,4 \\
(25)\end{array}$ & $\begin{array}{l}20,9 \pm 5,2 \\
(26)\end{array}$ & NS \\
\hline final & $\begin{array}{l}44,8 \pm 12,5 \\
(13)\end{array}$ & $\begin{array}{l}42,8 \pm 8,6 \\
(21)\end{array}$ & $\begin{array}{l}40,8 \pm 8,0 \\
(25)\end{array}$ & $\begin{array}{l}43,1 \pm 7,6 \\
(25)\end{array}$ & NS \\
\hline RNAm $^{\mathbf{b}}$ & $\begin{array}{l}113,3 \pm 7,2 \\
(12)^{\text {* }}\end{array}$ & $\begin{array}{l}96,3 \pm 6,8 \\
(19)\end{array}$ & $\begin{array}{l}95,3 \pm 6,3 \\
(20)^{\#}\end{array}$ & $\begin{array}{l}100 \\
(20)\end{array}$ & $\begin{array}{l}\text { \& }<0,05 \text { para } \\
\text { símbolos } \\
\text { diferentes }\end{array}$ \\
\hline
\end{tabular}

Cada valor de expressão do RNAm foi normalizado em relação ao RNAm de GAPDH e expresso em valor relativo ao controle.

Comparação estatística: a CETP basal $\mathrm{x}$ final, teste $\mathrm{t}$ de Student pareado, $\mathrm{p}<0,001$ para todos os grupos. b RNAm, ANOVA, seguida de pós-teste de múltipla comparação de Newman-Keuls, p<0,05 para símbolos diferentes.

NS: não significativo

Sobre a atividade das enzimas LLH, LLP e LCAT, não houve diferença entre os grupos (Tabela 4).

Tabela 4. Atividade de lipoproteína-lipase hepática (LLH) e periférica (LLP) (nmol $\mathrm{FFA} / \mathrm{mL} / \mathrm{h}$ ) e de LCAT (\%) ao final de 19 semanas de tratamento.

\begin{tabular}{l|l|l|l|l|l}
\hline & EE & Iso Low & Iso High) & Controle & \\
\hline LLH & $3514 \pm 122$ & $3833 \pm 147$ & $3710 \pm 110$ & $3661 \pm 141$ & NS \\
& $(9)$ & $(8)$ & $(9)$ & $(8)$ & \\
\hline LLP & $1424 \pm 113$ & $1429 \pm 165$ & $1343 \pm 171$ & $1201 \pm 431$ & NS \\
& $(9)$ & $(8)$ & $(9)$ & $(8)$ & \\
\hline LCAT & $10,2 \pm 7,9(7)$ & $10,3 \pm 3,2(10)$ & $10,0 \pm 4,6(11)$ & $9,2 \pm 3,8(11)$ & NS \\
\hline
\end{tabular}

LLH e LLP: valores apresentados em mediana \pm erro padrão;

LCAT: valores apresentados em média \pm desvio padrão;

Comparação estatística: Kruskal-Wallis.

NS: não significativo 


\subsection{Peso uterino e análise histológica dos úteros}

A média de peso uterino foi maior no grupo EE (Tabela 5). No Anexo 5 são mostrados os úteros à época do sacrifício de um animal intacto, ou seja, não ooforectomizado, de um animal do grupo Controle, isto é, ooforectomizado sem tratamento e de um animal do grupo EE.

Tabela 5. Peso uterino (g) dos animais após 19 semanas de tratamento.

\begin{tabular}{c|l|l|l}
\hline EE (13) & Iso Low (25) & Iso High (28) & Controle (28) \\
\hline $0,4 \pm 0,1^{\star}$ & $0,06 \pm 0,1^{\#}$ & $0,1 \pm 0,1^{\#}$ & $0,07 \pm 0,07^{\#}$ \\
\hline
\end{tabular}

Os valores representam a média $\pm \mathrm{DP}$.

Os valores em parênteses indicam o número de animais em cada grupo.

Comparação estatística: ANOVA, com pós-teste de múltipla comparação de Newman-Keuls, $p<0,05$ para símbolos diferentes.

$\mathrm{Na}$ análise histológica (Anexo 6) foram feitas as seguintes observações:

- $\mathrm{EE}(\mathrm{n}=11)$ : apresentaram mucosa cérvico-vaginal revestida por epitélio escamoso estratificado, de espessura dentro dos limites da normalidade, mostrando evidente diferenciação da camada de células basais com a camada de células de Malphigi; presença de células superficiais queratinizadas, mas ausência de camada de queratina. $\mathrm{O}$ estroma é frouxo, apresentando aspecto mixóide. Em áreas focais observam-se polimorfonucleares ao redor dos vasos. A endocérvice mostra numerosas glândulas dilatadas. Não foram observadas alterações de malignidade nos tecidos examinados (mitose, atipia ou desarranjo arquitetural). Dois animais apresentaram o corpo uterino transformado em uma grande formação nodular, constituída por tecido necrosado, o que pode ter resultado na morte dos mesmos antes do final do estudo. 
- Iso Low ( $\mathrm{n}=8)$ : três animais apresentaram mucosa cérvico-vaginal de aspecto intermediário entre a do grupo Controle e do grupo Iso High. Observa-se camada mais espessa de células ao lado de áreas de espessura diminuída com diferenciação entre a camada basal e a camada de células de Malphigi. Presença de células mucosas sobre o epitélio escamoso. O estroma é denso e sem processo inflamatório. $\mathrm{O}$ epitélio glandular mostrou glândulas pouco dilatadas apresentando padrão intermediário entre os animais Controle e Iso High. Cinco animais apresentaram epitélio cérvico-vaginal de espessura muito reduzida.

- Iso High $(\mathrm{n}=8)$ : apresentaram epitélio semelhante ao do grupo EE. Em áreas focais há presença de pequena camada de queratina e há diferenciação entre a camada basal e a camada de Malphighi. Presença de células mucosas sobre o epitélio escamoso. O estroma variou de denso a frouxo, mas sem aspecto mixóide e sem processo inflamatório. A endocérvice mostrou glândulas dilatadas e em maior número que o grupo Iso Low.

- Controle $(n=7)$ : apresentaram mucosa cérvico-vaginal revestida por epitélio escamoso estratificado, de espessura muito reduzida, constituída por células basais e parabasais. Ausência de células intermediárias e superficiais. $\mathrm{O}$ estroma é denso e de aspecto fibroso e não apresenta infiltrado inflamatório. A endocérvice mostrou-se pouco glandular.

\subsection{Concentração plasmática de estrogênio}

A concentração plasmática de estrogênio $(\mathrm{pg} / \mathrm{mL})$ nos grupos de animais ooforectomizados $(n=14)$ no período basal variou de $<7,8$ a 15,8 . No grupo EE $(n=5)$ após o tratamento, a concentração chegou a $128,3 \pm 49,2$, enquanto que nos demais (Iso Low, n=3; Iso High, $n=3$; Controle, $n=3$ ) variou de $<7,8$ a 31,6. 


\section{7 Área de lesão aterosclerótica}

Na Tabela 6 são mostrados os dados dos grupos analisados separadamente e também dos grupos Iso Low e Iso High juntos.

Tabela 6. Área $\left(\mu \mathrm{m}^{2} \times 10^{3}\right)$ de lesão aterosclerótica.

\begin{tabular}{c|c|c|c|c}
\hline EE (14) & Iso Low (24) & Iso High (24) & $\begin{array}{c}\text { Iso Low + } \\
\text { Iso High (48) }\end{array}$ & Controle (22) \\
\hline $22,0 \pm 19,5^{*}$ & $12,3 \pm 9,9^{\#}$ & $7,4 \pm 6,4^{\#}$ & $9,9 \pm 8,6^{\#}$ & $10,7 \pm 12,8^{\#}$ \\
\hline
\end{tabular}

Valores representam a média \pm DP.

Os valores entre parênteses representam o número de animais nos respectivos grupos.

Comparação estatística: ANOVA com pós-teste de Newman-Keuls, p<0,01 para símbolos diferentes.

A freqüência de animais com área de lesão maior que a mediana do grupo Controle $\left(8,1 \mu \mathrm{m}^{2} \times 10^{3}\right)$ foi maior no grupo EE, comparado ao grupo Iso Low e este, por sua vez, maior que no Iso High (Figura 4).

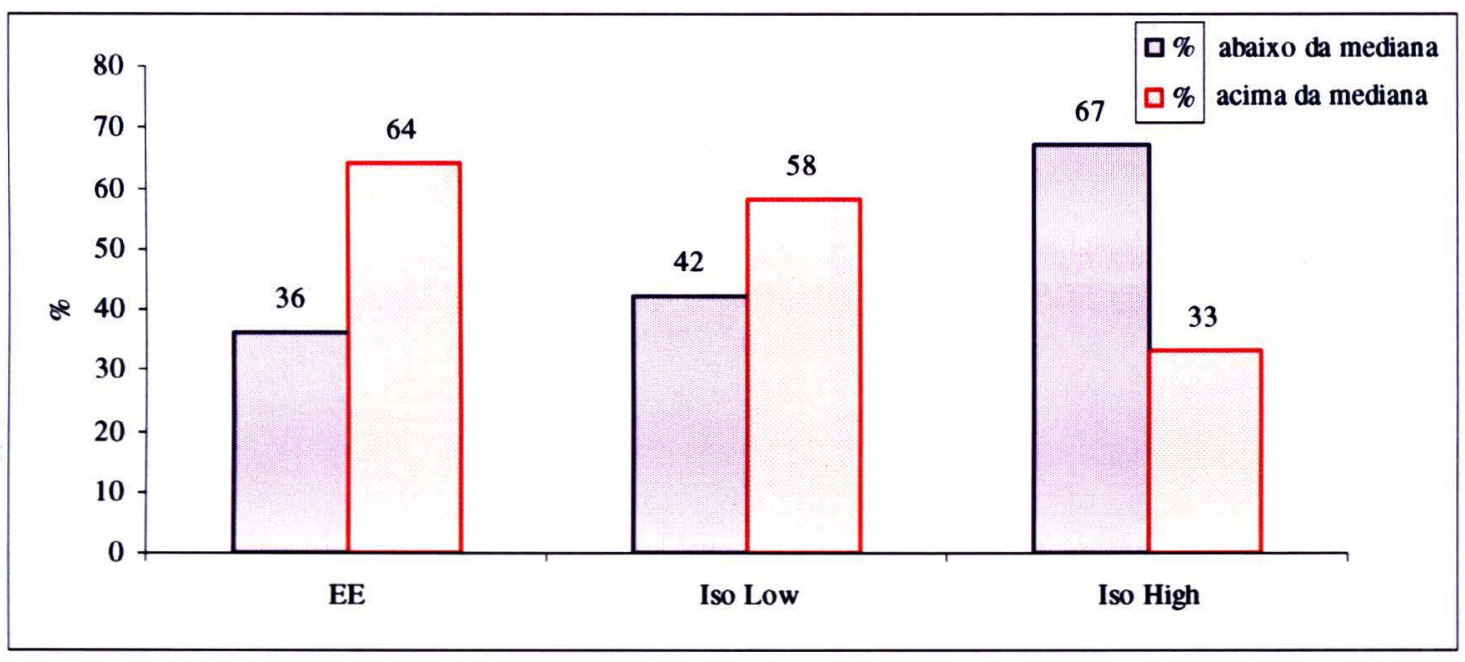

Figura 4. Freqüência da distribuição (\%) dos animais de acordo com dois níveis de tamanho de lesão aterosclerótica, segundo mediana do grupo Controle $\left(8,1 \mu \mathrm{m}^{2} \times 10^{3}\right)$. Teste do $\chi^{2}\left(\chi^{2}=4.476\right.$; graus de liberdade $=2 ; \mathrm{p}=0.1067$ ). 


\subsection{Anticorpos anti-LDL oxidada (ox-LDL) e anti-ApoB-D}

A concentração de anticorpos anti ApoB-D foi maior no grupo $\mathrm{EE}$, quando comparado aos demais grupos; já a de anti-ox-LDL foi maior no grupo EE apenas quando comparado ao Controle (Tabela 7). Estes resultados se mantêm mesmo quando juntamos os dados do grupos Iso Low e Iso High.

Tabela 7. Determinação de auto-anticorpos anti-ox-LDL e anti-ApoB-D no plasma de camundongos após 19 semanas de tratamento.

\begin{tabular}{c|c|c|c|c|c}
\hline & EE (7) & Iso Low (8) & Iso High (10) & $\begin{array}{c}\text { Iso High + } \\
\text { Iso Low (18) }\end{array}$ & Controle (13) \\
\hline ox-LDL & $0,86 \pm 0,23^{\star}$ & $0,76 \pm 0,10^{\star \#}$ & $0,69 \pm 0,16^{*}$ & $0,71 \pm 0,14^{\star \#}$ & $0,62 \pm 0,15^{\#}$ \\
\hline ApoB-D & $0,84 \pm 0,18^{*}$ & $0,68 \pm 0,06^{\#}$ & $0,67 \pm 0,14^{\#}$ & $0,68 \pm 0,11^{\#}$ & $0,61 \pm 0,14^{\#}$ \\
\hline
\end{tabular}

Os valores representam a média \pm DP da densidade óptica obtida a $450 \mathrm{~nm}$ e corrigida pela IgG total. Os valores entre parênteses indicam o número de animais dos respectivos grupos.

Comparação estatística: ANOVA, com pós-teste de comparação múltipla de Newman-Keuls: p<0,05 para símbolos diferentes. 


\subsection{Captação e remoção de colesterol}

No grupo Iso High a captação celular (Figura 5 A) de colesterol foi menor e a remoção (Figura 5 B) foi maior, quando comparado aos grupos Iso Low e Controle.

A)

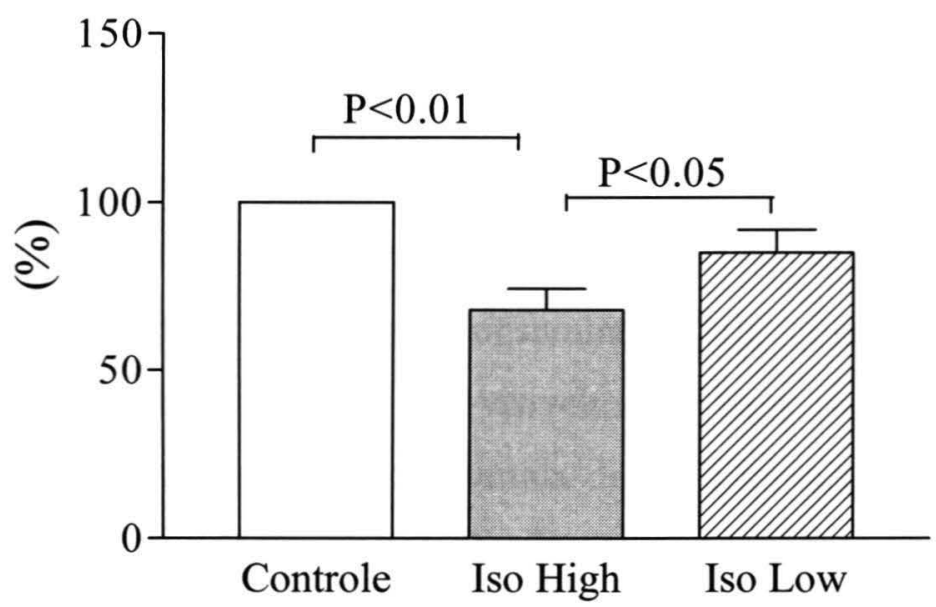

B)

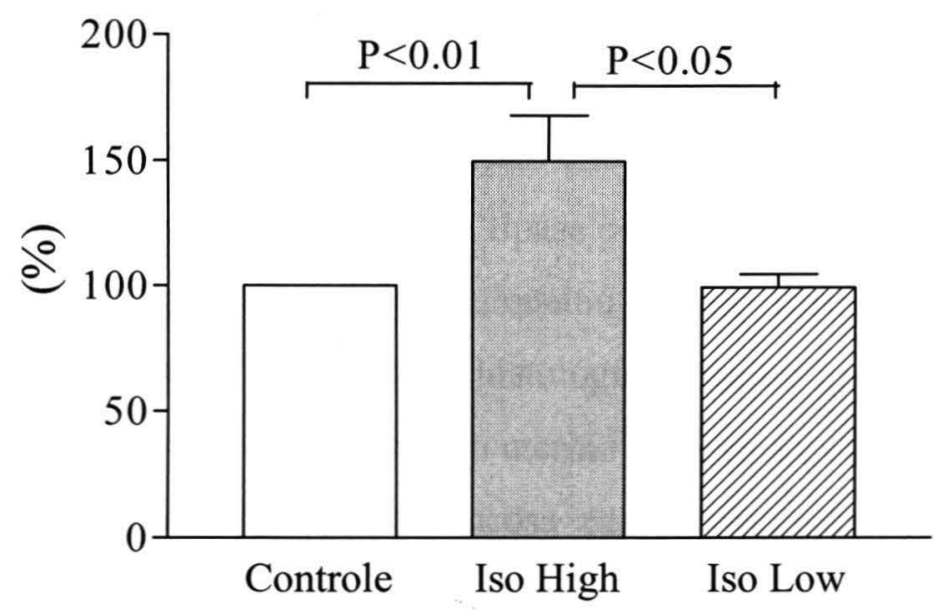

Figura 5. A) Captação relativa de colesterol de LDL humana acetilada por macrófagos de peritônio de camundongos. B) Remoção relativa de colesterol de LDL acetilada por HDL humana em macrófagos de peritônio de camundongos. 


\section{DISCUSSÃO}

Em camundongos a expressão da CETP e a deficiência parcial de receptores para LDL permitem que estes animais, que naturalmente não expressam esta proteína, adquiram um perfil lipídico semelhante ao humano, ou seja, o colesterol é transportado principalmente pelas LDL e secundariamente pelas HDL, diferentemente dos camundongos naturais, cuja fração principal é a HDL (Figuras 2 e 3).

Embora não tenha sido visto diferença na quantidade das dietas consumidas pelos grupos EE, Iso Low, Iso High e Controle, houve aumento do peso corporal nos três últimos (Tabela 2). Este aumento foi reflexo da maior quantidade de tecido adiposo abdominal, situação visível por ocasião do sacrifício dos animais. Ao contrário, no grupo $\mathrm{EE}$, mesmo consumindo dieta igual ao grupo Controle, a quantidade de tecido adiposo era visivelmente bem menor e atribuída à ação estrogênica, pois a quantidade consumida da dieta também não foi diferente entre este grupo e os três outros (Tabela 2). Similarmente aos nossos achados, no estudo de LUCAS et al (2003) os animais do grupo tratado com CEE tiveram menor peso corporal, quando comparado ao grupo controle.

Um trabalho (NAAZ et al., 2003) relata redução da expressão do RNAm da LLP em adipócitos de camundongos fêmeas C57BL6 ooforectomizadas e tratadas com injeção subcutânea de genisteína por 21 dias com conseqüente redução da quantidade de tecido adiposo, mas não encontramos qualquer diferença na atividade das enzimas lipase hepática (LLH), lipase periférica (LLP) ou da LCAT (Tabela 4).

A reposição estrogênica aumentou o peso uterino, comparado aos demais (Tabela 5 e Anexo 5). A análise histológica revelou que as isoflavonas exerceram algum efeito estrogênico no epitélio uterino (Anexo 6), como aumento da espessura e queratinização do epitélio da mucosa cérvico-vaginal. Resultados semelhantes, incluindo aumento do diâmetro da vagina e do útero, foram encontrados por CLINE et al. (2004), que alimentaram camundongos ooforectomizados deficientes para a expressão de ApoE (ApoE-/-) com dieta contendo em média 0,24mg de isoflavonas livre/g, por 16 semanas. $O$ útero apresenta grande quantidade de receptores $\beta$ de estrogênio, o que pode explicar os achados, pois as isoflavonas, por conta da 
homologia na estrutura com o estrogênio, se ligam a estes receptores (KUIPER et al., 1998; DEMONTY et al., 2003).

Para a determinação da concentração plasmática de estrogênios foram realizados três ensaios prévios. Nos dois primeiros ensaios, utilizando amostras de animais intactos e castrados, foi verificada a sensibilidade e a reprodutibilidade do método. No terceiro ensaio, utilizando apenas amostras de animais castrados $(n=17)$, estabelecemos os respectivos valores $(37,9 \pm 18,7 \mathrm{pg} / \mathrm{mL}$, média $\pm \mathrm{DP})$ como referência para o ensaio seguinte, no qual foram utilizadas as amostras dos animais submetidos aos tratamentos experimentais. Nota-se que o tratamento estrogênico acarretou concentrações no plasma consideravelmente superiores aos dos demais grupos, embora não tenham sido realizados testes estatísticos por número insuficiente de amostras.

A atividade da CETP não diferiu entre os grupos no período basal e nem após as 19 semanas de tratamento, no entanto, comparando-se os períodos, houve aumento da atividade após os tratamentos (Tabela 3), provavelmente ligada ao aumento da colesterolemia (Tabela 1), fato descrito por McPHERSON et al. (1991). A média da expressão (\%) hepática do RNAm da CETP (Tabela 3) foi menor nos grupos Iso Low $(96,3 \pm 6,8)$ e Iso High $(95,3 \pm 6,3)$ e maior no grupo $\mathrm{EE}(113,3 \pm 7,2)$, quando comparada ao Controle (100) mas as razões para isto são desconhecidas. Por outro lado, possivelmente esta variação não foi suficiente para alterar a atividade exógena da CETP plasmática, visto não ter sido encontrada qualquer diferença entre os grupos após os tratamentos experimentais. Também já foi descrito que há uma variação considerável na expressão de RNAm da CETP no fígado de animais que apresentam a mesma concentração plasmática de CETP (OU et al., 1999), sugerindo que não há uma boa relação entre o RNAm e a concentração de CETP.

No estudo de GREAVES et al. (2000), macacas ooforectomizadas tratadas com CEE tiveram colesterolemia mais alta do que aquelas tratadas com soja; CLARKSON et al. (2001), que também utilizaram o mesmo modelo animal, não encontraram diferença entre os dois tipos de tratamento no parâmetro citado. LUCAS et al. (2003) verificaram que a colesterolemia em hamsters tratados com estrógeno ou com isoflavonas não difere. No presente estudo, verificamos que não houve diferença na colesterolemia entre os grupos, mas a concentração do n-HDL-C foi menor no 
grupo EE, comparado ao Iso Low, sem ter sido diferente do Iso High (Tabela 1). No entanto, o primeiro apresentou maior área de lesão aterosclerótica, comparado aos demais (Tabela 6). Portanto, certamente há vários outros fatores determinantes da aterosclerose, além da concentração plasmática de lípides e lipoproteínas.

Considerando estes fatos, decidimos avaliar a captação e retirada celular de colesterol.

Encontramos que os macrófagos dos animais do grupo Iso High captam menos e liberam mais colesterol - este último processo mediado pelas partículas de HDL humana, quando comparados ao grupo Iso Low e Controle (Figura 5). Estes resultados são inéditos e indicam que as isoflavonas promovem alguma proteção contra o acúmulo de colesterol dentro das células, embora isto não tenha se refletido nas áreas de lesão aterosclerótica (Tabela 6).

Por falta de animais do grupo EE estes não foram incluídos no ensaio de cultura célula visto que aproximadamente $52 \%$ dos animais deste grupo morreram antes de completo o período estabelecido de 19 semanas de estudo. Quatro animais morreram quando do reimplante do pellet de estrogênio, possivelmente devido ao anestésico, mas nestes mesmos animais encontramos bexiga, rins e útero com aumento de volume. Outros quatro animais foram sacrificados e verificamos que estes apresentavam útero com volume bastante aumentado e, posteriormente, a análise histológica confirmou a presença de necrose no órgão de dois deles. No entanto não foi possível determinar a região de origem desta alteração, pois o útero estava completamente necrosado. Sete outros animais foram encontrados mortos e nestes não conseguimos fazer qualquer avaliação. Estes 15 animais não foram incluídos nos resultados finais.

MARSH et al. (1999) relatam o desenvolvimento de carcinoma de cérvix com invasão na uretra e na base da bexiga, resultando em obstrução do trato urinário e aumento do volume abdominal em $26 \%$ dos camundongos LDLr-/ooforectomizados e tratados com 17ßetinil-estradiol, por 84 dias, administrado por via subcutânea sob forma de pellet, liberando $6 \mu \mathrm{g} /$ dia. CAZITA et al. (2003), utilizando modelo animal semelhante e o mesmo tipo de hormônio (forma de administração e concentração), mas em um período menor (56 dias) não encontraram alterações no trato genito-urinário nos animais. Igualmente, utilizamos o mesmo tipo 
de hormônio, porém em um tempo maior, ou seja, 133 dias. Estes dados sugerem que a ação deletéria do $17 \beta$ etinil-estradiol no útero de camundongos seja tempodependente.

Embora o número de animais em cada grupo tenha sido suficiente quando comparado ao de outros trabalhos que utilizaram camundongos, não encontramos diferença estatisticamente significativa nas análises das áreas de lesão aterosclerótica entre os grupos Iso Low, Iso High e Controle, mas área maior no grupo EE, comparado aos demais (Tabela 6). Ocorreu também maior freqüência de animais com lesões superiores à mediana do grupo Controle em EE, enquanto em Iso High esta proporção foi inferior a Iso Low e mais inferior ainda do que em EE (Figura 4).

Com o objetivo de investigar outras variáveis no desenvolvimento da lesão aterosclerótica, avaliamos a presença de auto-anticorpos contra a ox-LDL e a ApoBD.

No grupo EE a geração de anticorpos anti-ox-LDL e anti-ApoB-D foi maior que nos demais grupos (Tabela 7). Em humanos os resultados ainda são controversos no que diz respeito à reposição hormonal e geração de anticorpos antiox-LDL em mulheres pós-menopausa. HEIKKINEN et al. (1998) não encontraram diferença nos títulos destes anticorpos após um ano de tratamento, enquanto que UINT et al. (2003) encontraram aumento destes títulos após 90 dias.

Foi visto que os títulos de autoanticorpos para ox-LDL se correlacionam positivamente com o conteúdo de ox-LDL nas lesões ateroscleróticas em camundongos deficientes para receptor de LDL (LDLr-/-) (TSIMIKAS et al., 2001) e que a concentração de ox-LDL está positivamente associada à severidade da doença coronariana nos humanos (EHARA et al., 2001).

Os trabalhos de WEN et al. (2000) e SANTANAM et al. (1998) mostram que os estrogênios em concentrações fisiológicas (136 a 1360 pg/mL) não são capazes de proteger as partículas de LDL contra a oxidação, mas que apenas em concentrações supra-fisiológicas (acima de $2000 \mathrm{pg} / \mathrm{mL}$ ) há uma ação antioxidante. É possível que a concentração plasmática de estrogênios encontrada nos nossos animais do grupo $\mathrm{EE}$ $(128,3 \pm 49,2 \mathrm{pg} / \mathrm{mL})$ não tenha sido suficiente para ter um comportamento antioxidante, resultando em aumento de títulos de auto-anticorpos anti-ox-LDL (Tabela 7). 
DAMASCENO et al. (2000) verificaram que os coelhos tratados com isoflavonas geram menos auto-anticorpos anti-ox-LDL, quando comparados aos animais alimentados com caseína. Este parâmetro não foi diferente nos nossos animais tratados com isoflavonas, quando comparados aos do grupo Controle.

Em humanos os resultados são controversos no que diz respeito à ação antioxidante das isoflavonas sobre a proteção contra a oxidação de LDL induzida por cobre. SAMMAN et al., (1999) não encontraram diferença no lag time do grupo tratado com isoflavonas ou com placebo, enquanto que MENG et al. (1999a) viram aumento do lag time.

No importante trabalho de revisão de HODGIN e MAEDA (2002) fica claro o efeito benéfico da reposição estrogênica (17ß-etinil estradiol) na redução da lesão aterosclerótica em camundongos ApoE-/- castrados, sejam machos ou fêmeas, mas o benefício foi acompanhado, ou derivado, da redução de lípides plasmático e, quando não houve alteração nos lípides, não houve redução da área de lesão (HODGIN et al., 2001). Da mesma forma, no trabalho de CAZITA et al. (2003), a área de lesão aterosclerótica bem como a quantidade dos títulos de autoanticorpos anti-ox-LDL e anti-ApoB-D dos camundongos fêmeas CETP+/- LDL+/- ooforectomizadas e tratadas com estrógeno não foi diferente do grupo controle - ooforectomizado não tratado e não foi visto alteração de CT plasmático.

Comparando os nossos resultados com outros de trabalhos que investigaram os efeitos da reposição estrogênica no desenvolvimento de lesões ateroscleróticas, este tipo de tratamento no modelo que utilizamos foi claramente prejudicial, verificado não apenas pela análise da lesão aterosclerótica, mas também pela quantificação dos títulos de autoanticorpos anti-ox-LDL e anti-ApoB-D, enquanto que as áreas de lesão aterosclerótica foram menores nos animais tratados com isoflavonas, comparados aos animais do grupo EE, no entanto sem diferença contra o grupo Controle (Tabela 6).

Em relação às isoflavonas, os resultados dos trabalhos experimentais mostram que os efeitos benéficos também são acompanhados, ou derivados, da redução da colesterolemia (MORTENSEN et al. 2004; ADAMS et al. 2004; KIRK et al. 1998).

Considerando estas observações, indagamos: se os nossos animais dos grupos experimentais tivessem colesterolemia mais baixa que os do grupo Controle, a área 
de lesão teria sido menor? Embora sejam conhecidos outros fatores importantes na patogênese da aterosclerose, nos trabalhos anteriores a concentração de lípides parece ter sido o fator principal na determinação da área de lesão aterosclerótica.

Fazendo um breve levantamento de trabalhos experimentais utilizando estrógenos e isoflavonas, resumimos os dados (Anexo 8.). Observa-se que em camundongos fêmeas ooforectomizadas a administração de estrógenos reduziu a formação de depósitos lipídicos arteriais nas quatro publicações (BOURASSA et al. 1996, ELAGE et al., 1997; SHULTZ et al., 2004; ADAMS et al., 2004) em que simultaneamente houve queda da colesterolemia. No estudo com macacas (CLARKSON et al., 2001) também se nota esta relação entre queda da colesterolemia e uso de CEE, como também de isoflavonas, e diminuição de aterosclerose.

Apesar de termos apresentado resultados diferentes daqueles já citados anteriormente, e considerando as limitações da utilização do modelo experimental descrito no presente trabalho para a fisiologia humana, os resultados encontrados no grupo EE estão em acordo com os achados das investigações populacionais HERS e WHI, nos quais houve aumento de risco para desenvolvimento de eventos cardiovasculares, embora tenha havido redução da colesterolemia e aumento da concentração de HDL-C.

Acreditando que o tratamento com o $17 \beta$-etinil-estradiol tenha sido de fato prejudicial no que se refere à lesão aterosclerótica, reunimos os dados dos animais dos grupos Iso Low e Iso High (Tabela 6): permaneceu a maior a lesão no grupo EE em relação ao do grupo tratado com isoflavonas e do Controle, sem que estes dois últimos diferissem entre si.

Nossos resultados indicam então que o estrógeno piora a aterogênese no modelo experimental usado, provavelmente por acelerar o estado oxidado das LDL in vivo e que, embora as isoflavonas exerçam ações biológicas potencialmente antiaterogênicas sobre o metabolismo de colesterol nos macrófagos, elas não se refletem em diminuição na área de gordura depositada nas artérias.

Nossos achados reforçam as recomendações atuais às mulheres menopausadas contra os estrógenos na TRH, mas não corroboram os resultados que mostram o benefício das isoflavonas na prevenção da aterosclerose. Assim, seria 
possível o emprego destas apenas se melhorarem os sintomas da menopausa, conforme recomenda a Sociedade Norte Americana de Menopausa (NAMS, 2004). 


\section{CONCLUSÕES}

Neste estudo, avaliamos a influência de uma dieta contendo isoflavonas e da reposição de $17 \beta$-etinil-estradiol no desenvolvimento da aterosclerose experimental em camundongos com hipercolesterolemia moderada, heterozigotos para a deficiência de receptores de LDL e transgênicos para a expressão de CETP humana.

Verificamos que as isoflavonas:

1) promovem a re-epitelização da mucosa cérvico-vaginal, portanto, apresentam efeito similar aos estrógenos sob este aspecto;

2) não modificam a concentração de lípides no plasma, porém aumentam a retirada de colesterol celular advindo de LDL acetilada e diminuem a captação desta por macrófagos de peritônio de camundongos, não obstante, estes efeitos benéficos não foram de magnitude suficiente para impedir o depósito de gordura nas aortas.

Quanto ao 17ß-etinil-estradiol, verificamos que este hormônio, sob forma de reposição:

1) causa crescimento anormal do útero em nossas condições experimentais;

2) reduz a concentração plasmática de n-HDL-C e, não obstante, piora o depósito de gordura na raiz da aorta, provavelmente devido ao aumento dos títulos de autoanticorpos contra ox-LDL e ApoB-D in vivo. 


\section{REFERÊNCIAS BIBLIOGRÁFICAS}

1. Adams MR, Golden DL, Anthony MS, Register TC, Williams JK. The inhibitory effect of soy protein isolate on atherosclerosis in mice does not require the presence of $\mathrm{LDL}$ receptors or alteration of plasma lipoproteins. $\mathrm{J}$ Nutr. 2002a;132(1):43-9.

2. Adams MR, Golden DL, Register TC, Anthony MS, Hodgin JB, Maeda N et al. The atheroprotective effect of dietary soy isoflavones in apolipoprotein E-/- mice requires the presence of estrogen receptor-alpha. Arterioscler Thromb Vasc Biol. 2002b;22(11):1859-64.

3. Adams MR, Golden DL, Franke AA, Potter SM, Smith HS, Anthony MS. Dietary soy beta-conglycinin (7S globulin) inhibits atherosclerosis in mice. $\mathrm{J}$ Nutr. 2004;134(3):511-6.

4. Adlercreutz H, Mazur W. Phyto-oestrogens and western diseases. Ann Med 1997;29:95-120.

5. Albertazzi P, Pansini F, Bonaccorsi G, Zanotti L, Forini E, De Aloysio D. The effect of dietary soy supplementation on hot flushes. Obstet Gynecol 1998;91(1):6-11.

6. Anderson JW, Johnsotone BM, Cook-Newell ME. Meta-analysis of the effects of soy protein intake on serum lipids. N Engl J Med 1995;333:276-82.

7. Asahi M, Yanagi S, Ohta S, Inazu T, Takeuchi F, Taniguchi T, Yamamura H. Thrombin-induced human platelet aggregation is inhibited by protein-tyrosine kinase inhibitors, ST638 and genistein. FEBS Lett 1992;309:10-4.

8. Baum JA, Teng H, Erdman Jr JW, Weigel RM, Klein BP, Persky VW et al. Long-term intake of soy protein improves blood lipid profiles and increases mononuclear cell low-density-lipoprotein receptor messenger RNA in hypercholesterolemic, postmenopausal women. Am J Clin Nutr 1998;68:545-51.

9. Basu SK, Goldstein JL, Anderson RGW, Brown MS. Degradation of cationized low density lipoprotein and regulation of cholesterol metabolism in homozygous familial hypercholesterolemia fibroblasts. Proc Natl Acad Sci U S A. 1976;73(9):3178-82. 
10. Bingham SA, Atkinson C, Liggins J, Bluck L, Coward A. Phyto-oestrogens: where are we now? Br J Nutr 1998;79:393-406.

11. Bowey E, Adlercreutz H, Rowland I. Metabolism of isoflavones and lignans by the gut microflora: a study in germ-free and human flora associated rats. Food Chem Toxicol 2003;41(5):631-6.

12. Borradaile NM, de Dreu LE, Wilcox LJ, Edwards JY, Huff MW. Soya phytoestrogens, genistein and daidzein, decrease apolipoprotein B secretion from HepG2 cells through multiple mechanisms. Biochem J. 2002;366(Pt 2):531-9.

13. Boschcov P, Juliano L, Gidlund M. Development of a peptide-based ELISA for the dection of antibodies against oxidized low density lipoprotein (oxLDL). Atherosclerosis 2000;151:224.

14. Bourassa PA, Milos PM, Gaynor BJ, Breslow JL, Aiello RJ. Estrogen reduces atherosclerotic lesion development in apolipoprotein E-deficient mice. Proc Natl Acad Sci U S A 1996;93(19):10022-7.

15. Brown MS, Goldstein JL. Lipoprotein metabolism in the macrophage: implications for cholesterol deposition in atherosclerosis. Annu Rev Biochem. 1983;52:223-61.

16. Cazita PM, Berti JA, Aoki C, Gidlund M, Harada LM, Nunes VS et al. Cholesteryl ester transfer protein expression attenuates atherosclerosis in ovariectomized mice. J Lipid Res 2003;44(1):33-40.

17. Clarkson TB, Anthony MS, Morgan TM. Inhibition of postmenopausal atherosclerosis progression: a comparison of the effects of conjugated equine estrogens and soy phytoestrogens. J Clin Endocrinol Metab 2001;86:41-7.

18. Cline JM, Franke AA, Register TC, Golden DL, Adams MR. Effects of dietary isoflavone aglycone on the reproductive tract of male and female mice. Toxicol Pathol 2004;32:91-9.

19. Damasceno NR, Goto H, Rodrigues FM, Dias CT, Okawabata FS, Abdalla DS, Gidlund M. Soy protein isolate reduces the oxidizability of LDL and the generation of oxidized LDL autoantibodies in rabbits with diet-induced atherosclerosis. J Nutr. 2000 Nov;130(11):2641-7. 
20. de Grooth GJ, Klerkx AH, Stroes ES, Stalenhoef AF, Kastelein JJ, Kuivenhoven JA. A review of CETP and its relation to atherosclerosis. J Lipid Res 2004;45(11):1967-74.

21. Demonty I, Lamarche B, Jones PJ. Role of isoflavones in the hypocholesterolemic effect of soy. Nutr Rev 2003;61(6 Pt 1):189-203.

22. Dobiasova, M., J. Stribrna, P. H. Pritshard and J. J. Frohlich. Cholesterol esterification rate in plasma depleted of very low and low density lipoproteins is controlled by the proportion of HDL2 and HDL3 subclasses: study in hypertensive and normal middle-aged and septuagenarian men. J Lipid Res 1992;33:1411-8.

23. Ehara S, Ueda M, Naruko T, Haze K, Itoh A, Otsuka M et al. Elevated levels of oxidized low density lipoprotein show a positive relationship with the severity of acute coronary syndromes. Circulation. 2001;103:1955-60.

24. Ehnholm C, Kuusi T. Preparation, characterization and measurement of hepatic lipase. Methods Enzymol 1986;129:716-38.

25. Elhage R, Arnal JF, Pieraggi MT, Duverger N, Fievet C, Faye JC, Bayard F. 17 beta-estradiol prevents fatty streak formation in apolipoprotein E-deficient mice. Arterioscler Thromb Vasc Biol 1997;17(11):2679-84.

26. Foger B, Chase M, Amar MJ, Vaisman BL, Shamburek RD, Paigen B et al. Cholesteryl ester tranfer protein corrects dysfunctional high density lipoprotein and reduces aortic atherosclerosis in lecithin cholesterol acyltranferase transgenic mice. J Biol Chem 1999;274:36912-20.

27. Fotsis T, Pepper M, Adlercreutz H, Fleischmann G, Hase T, Montesano R et al. Genistein, a dietary-derived inhibitor of in vitro angiogenesis. Proc Natl Acad Sci USA 1993;90:2690-4.

28. Grady D, Herrington D, Bittner V, Blumenthal R, Davidson M, Hlatky M, Hsia J, Hulley S, Herd A, Khan S, Newby LK, Waters D, Vittinghoff E, Wenger N; HERS Research Group. Cardiovascular disease outcomes during 6.8 years of hormone therapy: Heart and Estrogen/progestin Replacement Study follow-up (HERS II). JAMA 2002;288(1):49-57.

29. Greaves KA, Wilson MD, Rudel LL, Williams JK, Wagner JD. Consumption of soy protein reduces cholesterol absorption compared to casein protein alone or 
supplemented with an isoflavone extract or conjugated equine estrogen in ovariectomized cynomolgus monkeys. J Nutr 2000;130(4):820-6.

30. Hara H, Yokoyama S. Interaction of free apolipoproteins with macrophages. Formation of high density lipoprotein-like lipoproteins and reduction of cellular cholesterol. J Biol Chem. 1991 Feb 15;266(5):3080-6.

31. Havel RJ, Eder HA, Bragdon JH. The distribution and chemical composition of ultracentrifugally separated lipoproteins in human serum. J Clin Invest. 1955 Sep;34(9):1345-53.

32. Hayek T, Masucci-Magoulas L, Jiang X, Walsh A, Rubin E, Breslow JL, Tall AR. Decreased early atherosclerotic lesions in hypertriglyceridemic mice expressing cholesteryl ester transfer protein transgene. $\mathrm{J}$ Clin Invest 1995;96:2071-4.

33. Heikkinen AM, Niskanen L, Yla-Herttuala S, Luoma J, Tuppurainen MT, Komulainen M, Saarikoski S. Postmenopausal hormone replacement therapy and autoantibodies against oxidized LDL. Maturitas 1998;29(2):155-61.

34. Helisten H, Hockerstedt A, Wahala K, Tiitinen A, Adlercreutz H, Jauhiainen M et al. Accumulation of high-density lipoprotein-derived estradiol-17( fatty acid esters in low-density lipoprotein particles. J Clin Endocrinol Metab 2001;86:1294-300.

35. Hodgin JB, Maeda N. Minireview: estrogen and mouse models of atherosclerosis. Endocrinology 2002;143(12):4495-501.

36. Hodgin JB, Krege JH, Reddick RL, Korach KS, Smithies O, Maeda N. Estrogen receptor alpha is a major mediator of 17 beta-estradiol's atheroprotective effects on lesion size in Apoe-/- mice. J Clin Invest 2001;107(3):333-40.

37. Horiuchi T, Onouchi T, Takahashi M, Ito H, Orimo H. Effect of soy protein on bone metabolism in postmenopausal Japanese women. Osteoporos Int 2000;11:721-4.

38. Hulley S, Furberg C, Barrett-Connor E, Cauley J, Grady D, Haskell W, Knopp R, Lowery M, Satterfield S, Schrott H, Vittinghoff E, Hunninghake D; HERS Research Group. Noncardiovascular disease outcomes during 6.8 years of hormone therapy: Heart and Estrogen/progestin Replacement Study follow-up (HERS II). JAMA 2002 Jul 3;288(1):58-66. 
39. Kirk EA, Sutherland P, Wang SA, Chait A, LeBoueuf RC. Dietary isoflavones reduce plasma cholesterol and atherosclerosis in $\mathrm{C} 57 \mathrm{BL} / 6$ mice but not LDL receptor-deficient mice. J Nutr 1998;128:954-9.

40. Kuiper GG, Lemmen JG, Carlsson B, Corton JC, Safe SH, van der Saag PT, van der Burg B, Gustafsson JA. Interaction of estrogenic chemicals and phytoestrogens with estrogen receptor beta. Endocrinology 1998;139(10):425263.

41. Lamon-Fava S. Genistein activates apolipoprotein A-I gene expression in the human hepatoma cell line Hep G2. J Nutr 2000;130:2489-92.

42. Lowry OH, Rosebrough, NJ, Farr AL, Randall RJ. Protein measurement with the Folin phenol reagent. J Biol Chem 1951;193:265-75.

43. Lucas EA, Lightfoot SA, Hammond LJ, Devareddy L, Khalil DA, Daggy BP et al. Soy isoflavones prevent ovariectomy-induced atherosclerotic lesions in Golden Syrian hamster model of postmenopausal hyperlipidemia. Menopause 2003;10(4):314-21.

44. MacLennan A, Lester S, Moore V. Oral estrogen replacement therapy versus placebo for hot flushes: a systematic review. Climacteric 2001;4(1):58-74.

45. Mangueira CLP. Autoanticorpos anti-lipoproteína de baixa densidade oxidada na artrite reumatóide. Tese

46. Marotti KR, Castle CK, Boyle TP, Lin AH, Murray RW, Mechior GW. Severe atherosclerosis in transgenic mice expressing simian cholesteryl ester transfer protein. Nature 1993;364:73-5.

47. Marsh MM, Walker VR, Curtiss LK, Banka CL. Protection against atherosclerosis by estrogen is independent of plasma cholesterol levels in LDL receptor-deficient mice. J Lipid Res 1999;40:893-900.

48. McPherson R, Mann CJ, Tall AR, Hogue M, Martin L, Milne RW, Marcel YL. Plasma concentrations of cholesteryl ester transfer protein in hyperlipoproteinemia. Relation to cholesteryl ester transfer protein activity and other lipoprotein variables. Arterioscler Thromb. 1991 Jul-Aug;11(4):797-804.

49. Meng QH, Lewis $\mathrm{P}$, Wahala K, Adlercreutz H, Tikkanen MJ. Incorporation of esterified soybean isoflavones with antioxidant activity into low density lipoprotein. Biochem Biophys Acta 1999a;1438:369-76. 
50. Meng QH, Hockerstedt A, Heinonen S, Wahala K, Adlercreutz H, Tikkanen MJ. Antioxidant protection of lipoproteins containing estrogens: in vitro evidence for low- and high-density lipoproteins as estrogen carriers. Biochem Biophys Acta $1999 \mathrm{~b} ; 1439: 331-40$.

51. Messina M, Hughes C. Efficacy of soyfoods and soybean isoflavone supplements for alleviating menopausal symptoms is positively related to initial hot flush frequency. J Med Food 2003;6(1):1-11.

52. Montes GS, Luque EH. 1988. Effects of ovarian steroids on vaginal smears in the rat. Acta Anat 1988;133:192-9.

53. Mortensen A, Pilegaard K, Frandsen H, Breinholt V. Effect of a soy supplement on spontaneous atherosclerosis in low density lipoprotein receptor knock out (LDLR -/--) mice. Asia Pac J Clin Nutr 2004;13(Suppl):S102.

54. Murphy CT, Kellie S, Westwick J. Tyrosine-kinase activity in rabbit platelets stimulated with platelet-activating factor. The effect of inhibiting tyrosine kinase with genistein on platelet-signal-molecule elevation and functional responses. Eur J Biochem 1993;216:639-51.

55. Naaz A, Yellayi S, Zakroczymski MA, Bunick D, Doerge DR, Lubahn DB et al. The soy isoflavone genistein decreases adipose deposition in mice. Endocrinology 2003;144(8):3315-20.

56. NAMS - North American Menopause Society. Treatment of menopauseassociated vasomotor symptoms: position statement of The North American Menopause Society. Menopause. 2004;11(1):11-33

57. Ni W, Tsuda Y, Sakono M, Imaizumi K. Dietary soy protein isolate, compared with casein, reduces atherosclerotic lesion area in apolipoprotein E-deficient mice. J Nutr 1998;128(11):1884-9.

58. Ou J, Saku K, Jimi S, Liao YL, Ohta T, Zhang B et al. Combined effects of probucol and bezafibrate on lipoprotein metabolism and liver cholesteryl ester transfer protein mRNA in cholesterol-fed rabbits. Jpn Circ J 1999;63(6):471-7.

59. Paigen B, Morrow A, Holmes, PA, Mitchell D, Willians RA. Quantitative assessment of atherosclerotic lesions mice. Atherosclerosis 1987;68:231-40.

60. Plump AS, Masucci-Magoulas L, Bruce C. Increased atherosclerosis in ApoE and LDL receptor gene knock-out mice as a result of human cholesteryl ester 
transfer protein transgene expession. Arterioscler Thromb Vasc Biol 1999;19:1105-10.

61. Rubin EM, Krauss RM, Spangler EA, Verstuyft JG, Clift SM. Inhibition of early atherogenesis in transgenic mice by human apolipoprotein AI. Nature. 1991 Sep $19 ; 353(6341): 265-7$.

62. Samman S, Wall PML, Chan GSM, Smith SJ, Petocz P. The effect of supplementation with isoflavones on plasma lipids and oxidisability of low density lipoprotein in premenopausal women. Atherosclerosis 1999;147:277-83.

63. Santanam N, Sher-Brewer R, McClatchey R, Castellano PZ, Murphy AA, Voelkel S et al. Estradiol as an antioxidant: incompatible with its physiological concentrations and function. J Lip Res 1998;39:2111-8.

64. Sarkar FH, Li Y. Soy isoflavones and cancer prevention. Cancer Invest 2003;21(5):744-57.

65. Setchell KDR, Brown N, Lydeking-Olsen E. The clinical importance of the metabolite equol - a clue to the effectiveness of soy and its isoflavone. J Nutr 2002;132:3577-84.

66. Shimokado K, Yokota T, Umezawa K, Sasaguri T, Ogata J. Protein tyrosine kinase inhibitors inhibit chemotaxis of vascular smooth muscle cells. Arterioscler Thromb 1994;14:973-81.

67. Shultz JM, Zhu XD, Knopp RH, Leboeuf RC, Rosenfeld ME. Norgestimate and medroxyprogesterone acetate do not attenuate the atheroprotective effects of 17 beta-estradiol in ovariectomized, apolipoprotein E-deficient mice. Fertil Steril. 2004;82 Suppl 3:1133-9.

68. Tall, AR. Plasma lipid transfer proteins. J Lip Res 1984;27:361-7.

69. Tikkanen MJ, Wahala K, Ojala S, Vihma V, Adlercreutz H. Effect of soybean phytoestrogen intake on low density lipoprotein oxidation resistance. Proc Natl Acad Sci USA 1998;95:3106-10.

70. Tsimikas S, Palinski W, Witztum JL. Circulating autoantibodies to oxidized LDL correlate with arterial accumulation and depletion of oxidized LDL in LDL receptor-deficient mice. Arterioscler Thromb Vasc Biol 2001;21:95-100. 
71. Turner NJ, Thomson BM, Shaw IC. Bioactive isoflavones in functional foods: the importance of gut microflora on bioavailability. Nutr Rev 2003;61(6 Pt 1):204-13.

72. Uint L, Gebara OCE, Pinto LB, Wajngarten M, Boschov P, da Luz PL et al. Hormone replacement therapy increases levels of antibodies against heat shock protein 65 and certain species of oxidized low density lipoprotein. Braz J Med Biol Res 2003;36:491-4.

73. Vadlamudi S, MacLean P, Green T, Shukla N, Bradfield J, Vore S et al. Role of female sex steroids in regulating cholesteryl ester transfer protein in transgenic mice. Metabolism 1998;47:1048-51.

74. Vannucchi CI, Satzinger S. Técnica de citologia vaginal como método de diagnóstico da fase do ciclo estral em cadelas. Clínica veterinária 1997;9:14-9.

75. Wang Y, Jones PJ, Ausman LM. Lichtenstein AH. Soy protein reduces triglyceride levels and triglyceride fatty acid fractional synthesis rate in hypercholesterolemic subjects. Atherosclerosis 2004;173(2):269-75

76. Weggemans RM, Trautwein EA. Relation betwee soy associated isoflavones and LDL and HDL cholesterol concentrations in humans: a meta-analysis. Eur J Clin Nutr 2003;57:940-6.

77. Writing Group for the Women's Health Initiative Investigators. Risks and Benefits of Estrogen Plus Progestin in Healthy Postmenopausal Women: Principal Results From the Women's Health Initiative Randomized Controlled Trial. JAMA 2002;288:321-33.

78. Yamakoshi J, Piskula MK, Izumi T, Tobe K, Saito M, Kataoka S et al. Isoflavone aglycone-rich extract without soy protein attenuates atherosclerosis development in cholesterol-fed rabbits. J Nutr 2000;130:1887-93.

79. Yuan JM, Wang QS, Ross RK et al. Diet and risk of breast cancer in Shanghai and Tianjin, China. Br J Cancer 1995;71:1353-8.

80. Zhang C, Zhuang Y, Qiang H, Liu X, Xu R, Wu Y. Relationship between endogenous estrogen concentrations and serum cholesteryl ester transfer protein concentrations in Chinese women. Clin Chem Acta 2001;314:77-83. 
81. Zhuo XG, Melby MK, Watanabe S. Soy isoflavone intake lowers serum LDL cholesterol: a meta-analysis of 8 randomized controlled trials in humans. J Nutr 2004;134(9):2395-400.

82. Zuckerman SH, Evans GF, Schelm JA, Eacho PI, Sandusky G. Estrogenmediated increases in LDL cholesterol and foam cell-containing lesions in human ApoB100xCETP trangenic mice. Arterioscler Thromb Vasc Biol 1999;19:147683. 
ANEXOS 
Anexo 1 - Composição centesimal da dieta padrão comercial Nuvilab CR-1.

\begin{tabular}{c|c}
\hline nutriente & $\%$ \\
\hline proteínas & 22,3 \\
gordura & 5,1 \\
carboidrato & 54,6 \\
resíduo mineral & 7,8 \\
umidade & 10,2 \\
Kcal & 280 \\
\hline
\end{tabular}

Fonte: Nuvital Nutrientes Ltda. 
Anexo 2 - Conteúdo de isoflavonas totais e livres.

\begin{tabular}{c|cc|cc}
\cline { 2 - 5 } & \multicolumn{2}{|c|}{ SuproSoy } & \multicolumn{2}{c}{ AWISP } \\
\hline Todas as formas * & $\mathrm{mg} / \mathrm{g}$ produto $\mathrm{mg} / \mathrm{g}$ proteína & $\mathrm{mg} /$ produto & $\begin{array}{c}\mathrm{mg} / \mathrm{g} \\
\text { proteína }\end{array}$ \\
\hline Genistina & 1.83 & 2.18 & 0.03 & 0.04 \\
Daidzina & 1.39 & 1.66 & 0.02 & 0.02 \\
Glicitina & 0.33 & 0.40 & 0.01 & 0.01 \\
Isoflavonas totais & 3.55 & 4.24 & 0.06 & 0.07 \\
\hline Isoflavonas livres & & & & 0.03 \\
\hline Genisteína & 1.10 & 1.31 & 0.02 & 0.01 \\
Daidzeína & 0.84 & 1.00 & 0.01 & 0.01 \\
Gliciteína & 0.20 & 0.24 & 0.01 & 0.05 \\
\hline Total isoflavonas livres & 2.14 & 2.55 & 0.04 & \\
\hline
\end{tabular}

Fonte: Solae Company, EUA

*Agliconadas (livres), $\beta$-glicosiladas (conjugadas com glicose) e esterificadas. 
Anexo 3. Caracterização e duração do ciclo estral de camundongos fêmeas.

\begin{tabular}{|c|c|c|c|}
\hline FASE & $\begin{array}{l}\text { DURAÇÃO } \\
\text { (horas) }\end{array}$ & TIPO CELULAR & VISUALIZAÇÃO \\
\hline pró-Estro & 12 & $\begin{array}{c}\text { superficiais e } \\
\text { intermediárias; } \\
\text { cianófilas (azuis) } \\
\text { eosinófilas } \\
\text { (vermelhas) }\end{array}$ & $\begin{array}{l}\text { células alaranjadas grandes } \\
\text { com halo azul e com núcleos } \\
\text { grandes. }\end{array}$ \\
\hline $\begin{array}{c}\text { estro } \\
\text { (ovulação) }\end{array}$ & 30 & $\begin{array}{l}\text { eosinófilas, } \\
\text { corneiformes }\end{array}$ & $\begin{array}{l}\text { células alaranjadas grandes } \\
\text { anucleada, parecem folhas. }\end{array}$ \\
\hline metaestro & 6 & $\begin{array}{l}\text { superficiais, } \\
\text { eosinófilas, } \\
\text { corneiformes, } \\
\text { leucócitos }\end{array}$ & $\begin{array}{c}\text { muitas células azuis e } \\
\text { vermelhas pequenas; células } \\
\text { vermelhas grandes. }\end{array}$ \\
\hline $\begin{array}{c}\text { diestro } \\
\text { (fase final do } \\
\text { ciclo) }\end{array}$ & 48 & $\begin{array}{l}\text { parabasais, } \\
\text { cianófilas, } \\
\text { leucócitos }\end{array}$ & $\begin{array}{l}\text { muitas células azuis pequenas e } \\
\text { com núcleo grande. }\end{array}$ \\
\hline $\begin{array}{l}\text { anestro } \\
\text { (epitélio } \\
\text { atrófico) }\end{array}$ & - & $\begin{array}{l}\text { parabasais e } \\
\text { basais }\end{array}$ & $\begin{array}{l}\text { muitas células azuis pequenas } \\
\text { e com núcleo grande. }\end{array}$ \\
\hline
\end{tabular}

O epitélio vaginal é classificado histologicamente como estratificado pavimentoso, sendo particularmente sensível às alterações hormonais, em especial à ação dos estrogênios. $\mathrm{O}$ epitélio da vagina responde de forma característica a esta ação hormonal, o que permite diferenciar cada fase do ciclo estral pela presença de determinados tipos celulares. A principal ação dos estrogênios é promover o espessamento do epitélio, tornando as células do lúmen vaginal cada vez mais distantes de seu suprimento sangüíneo e promovendo assim proteção à mucosa no momento da cópula. Neste sentido, as diferentes células encontradas na citologia vaginal designam distintos estágios de morte celular da lâmina própria em direção ao lúmen vaginal como descrito por VANNUCCHI et al, 1997. 
Estas mudanças podem ser monitoradas pela citologia vaginal de células que descamam do epitélio utilizando métodos de coloração apropriados.

Tipos celulares (da base para a superfície):

- célula basal: pequena, forma arredondada, núcleo grande, citoplasma azul (cianófilas).

- célula parabasal: pequena, arredondada, núcleo grande, cianófilas.

- célula intermediária: tamanho médio, forma oval, núcleo médio, cianófilas

- célula superficial: tamanho grande, forma poligonal, núcleo pequeno, cianófilas

- célula corneiforme: tamanho grande, forma poligonal, anucleada, eosinófillas 
Anexo 4. Citologia vaginal conforme o ciclo estral dos animais. Aumento de 10 vezes.

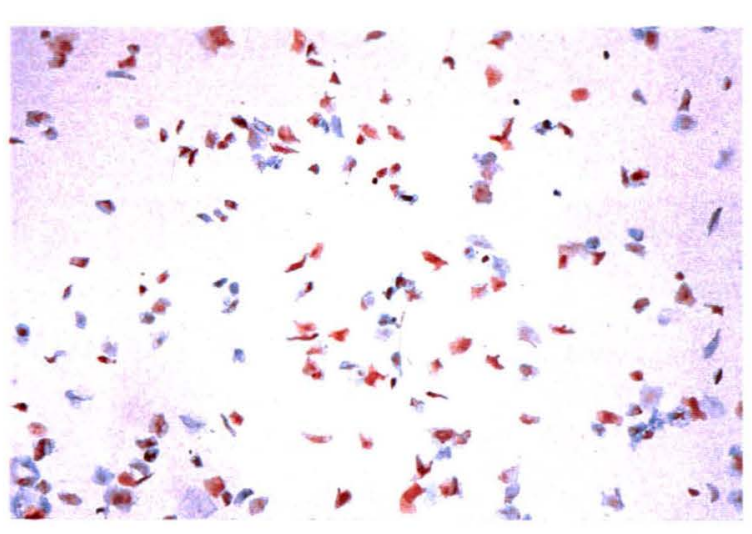

Proestro, com duração de 12 horas.

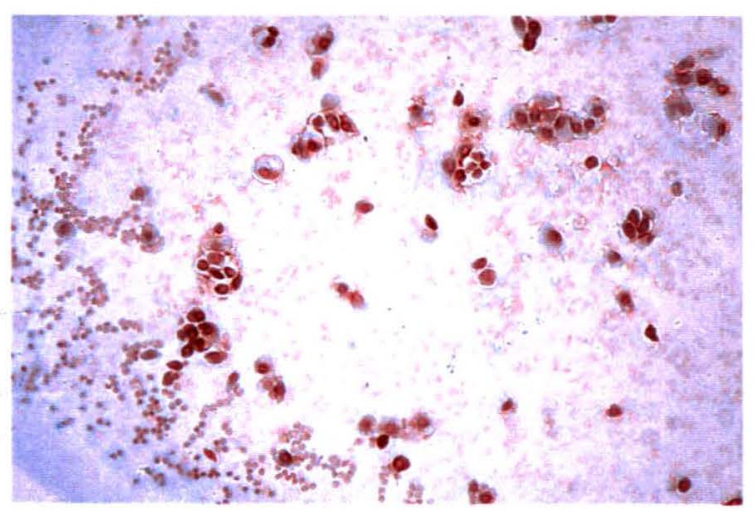

Metaestro, com duração de 6 horas.

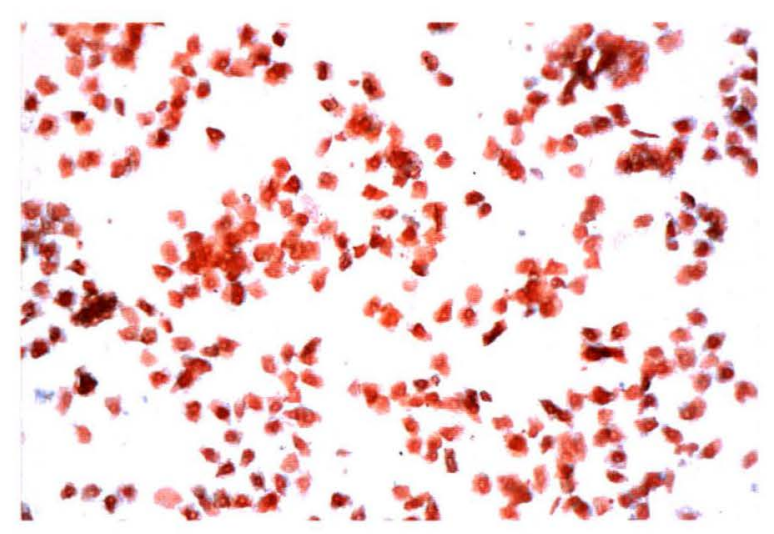

Estro, com duração de 30 horas.

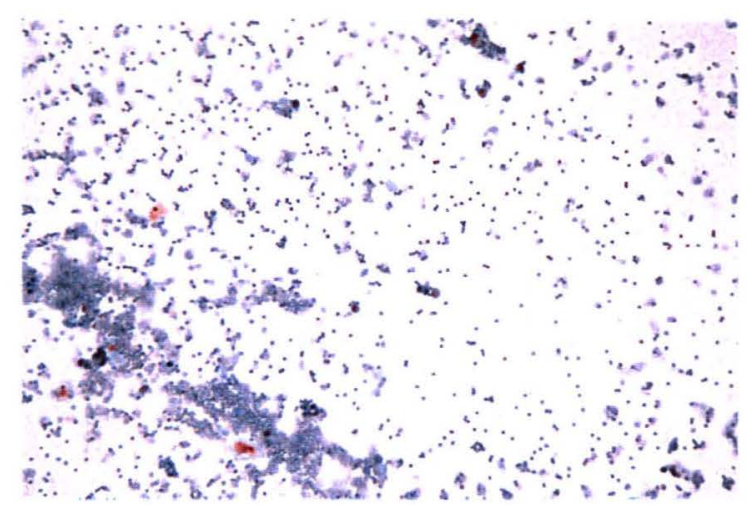

Diestro, com duração de 48 horas

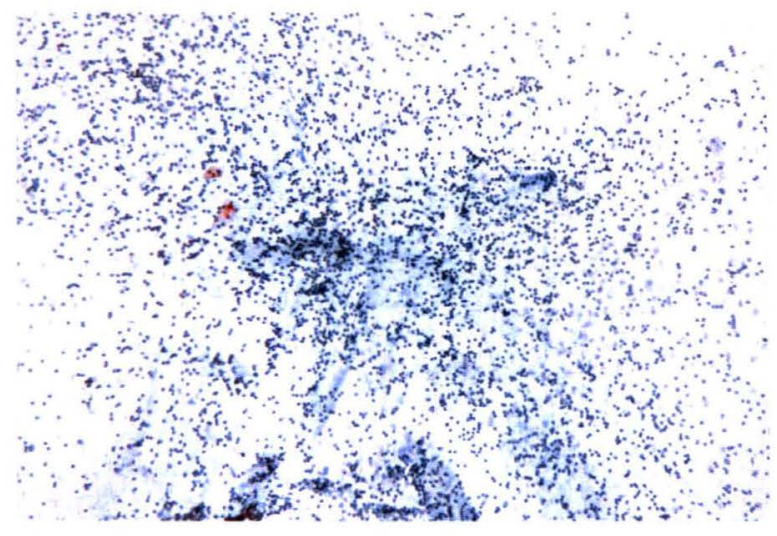

Anestro 
Anexo 5. Avaliação macroscópica dos úteros.

Ilustrado em tamanho maior que o natural. O útero do animal intacto mede aproximadamente três centímetros.

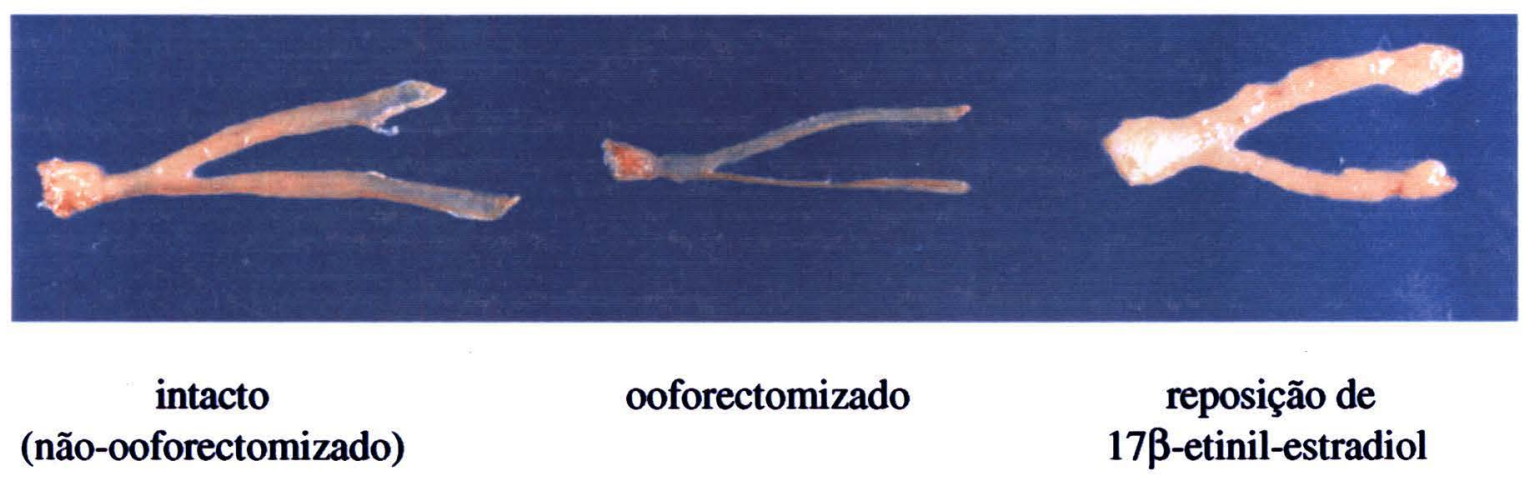




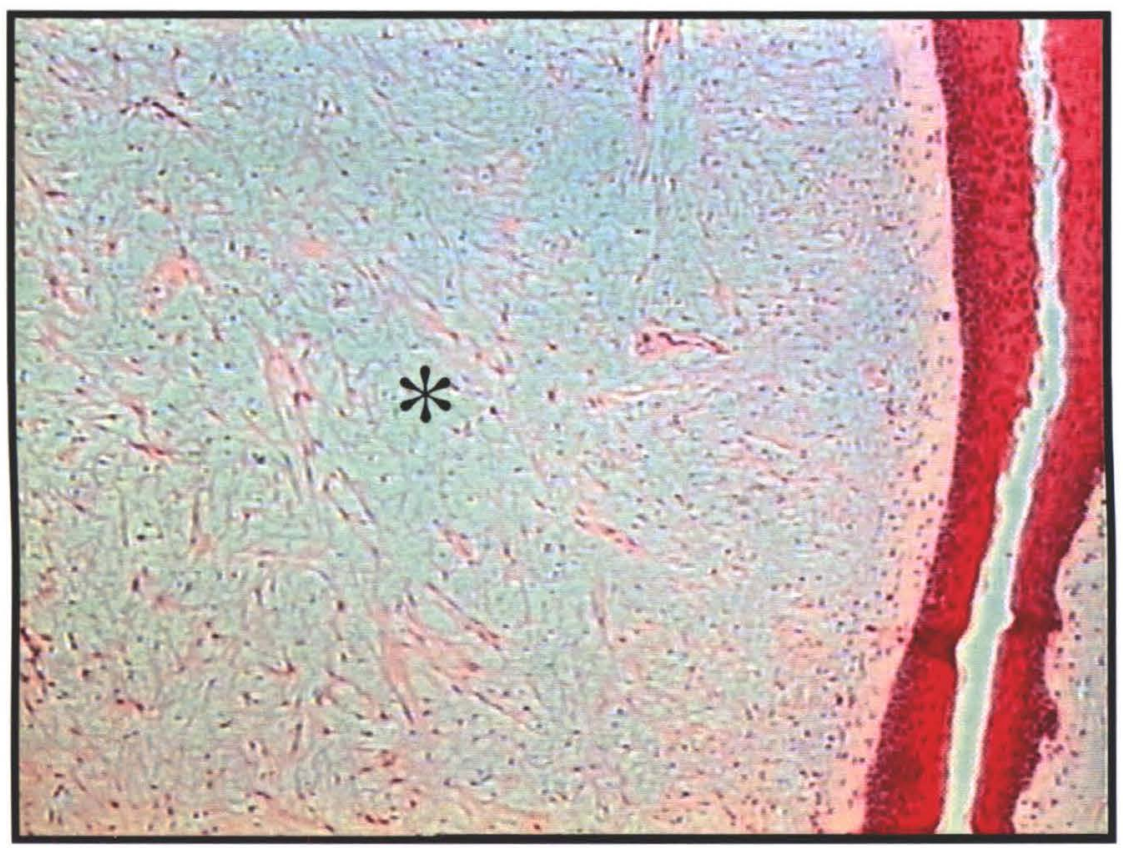

Figura 1. Animal do grupo EE.

Ectocérvice revestida por epitélio escamoso estratificado de espessura dentro dos limites da normalidade (seta), mostrando evidente diferenciação entre as camadas de células. Presença de células superficiais queratinizadas e ausência de camada de queratina. $\mathrm{O}$ estroma é frouxo e de aspecto mixóide (*). HE x 40 .

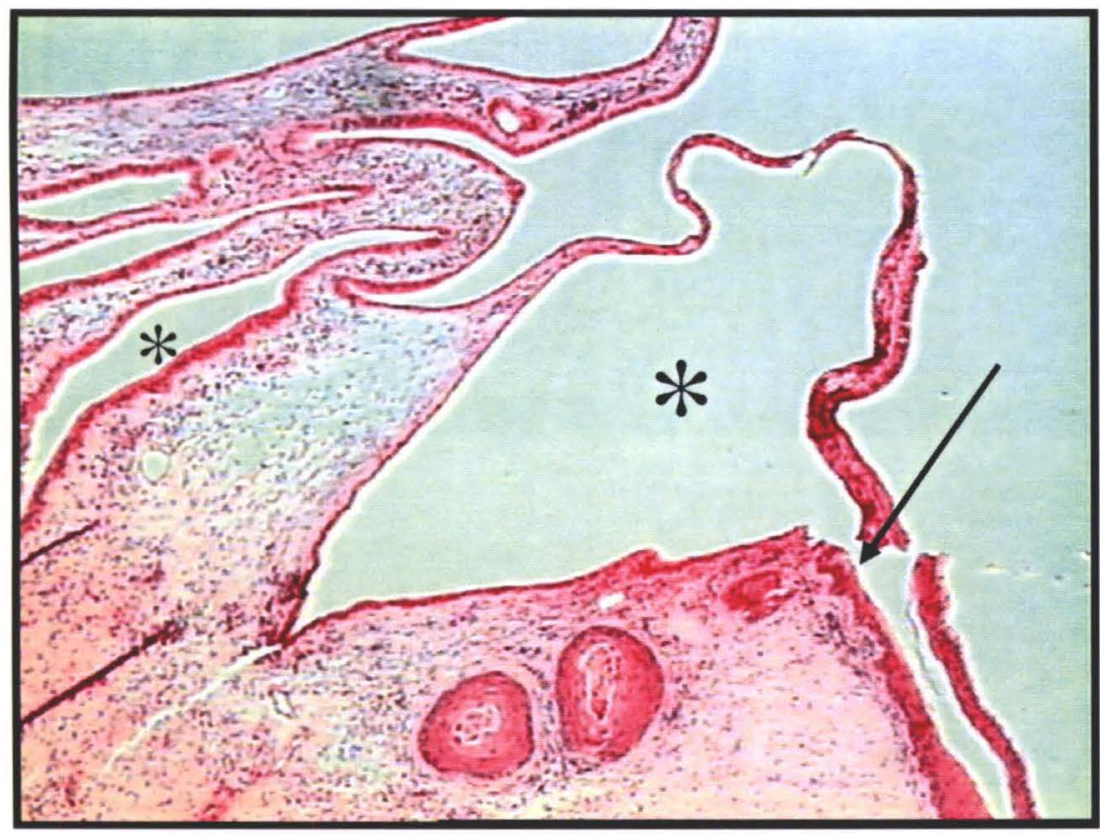

Figura 2. Animal de grupo EE.

Endocérvice mostrando numerosas glândulas dilatadas (*). Notar junção ecto-endocervical (seta). HE x 40. 


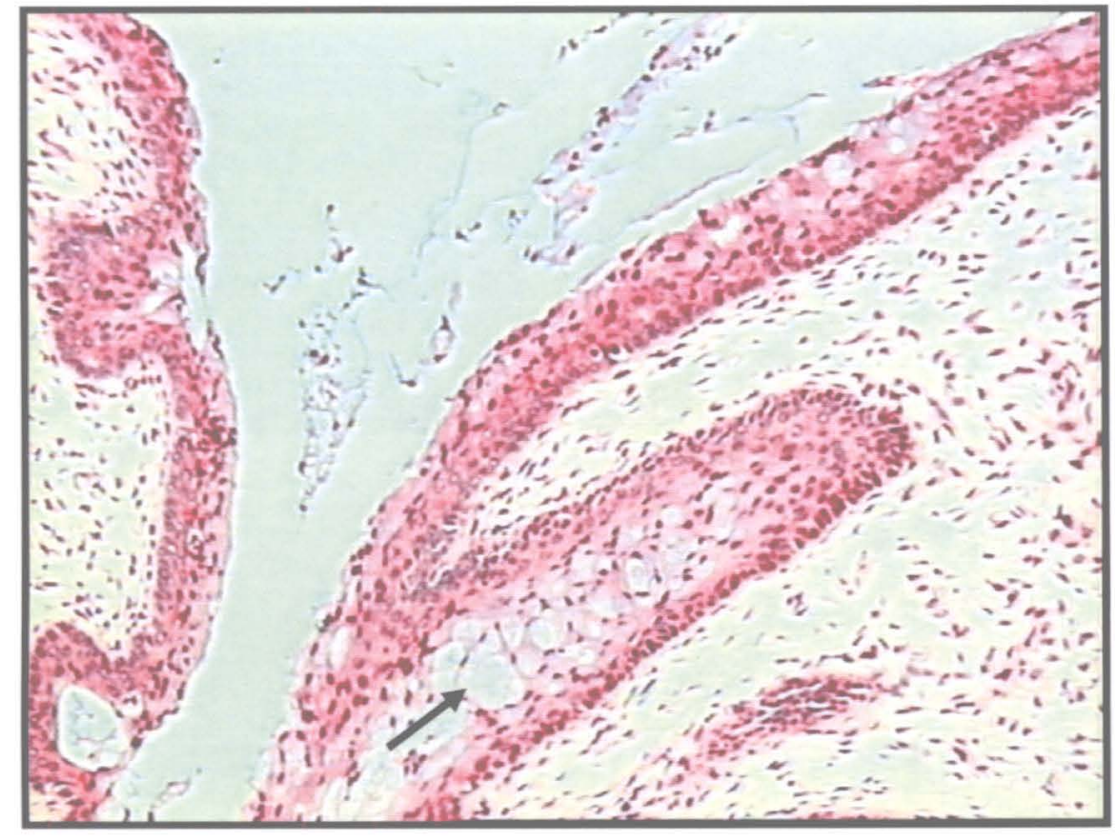

Figura 3. Animal do grupo Iso Low.

Ectocérvice revestida por epitélio escamoso estratificado de espessura média e com células mucosas na sua superfície (seta). HE x100.

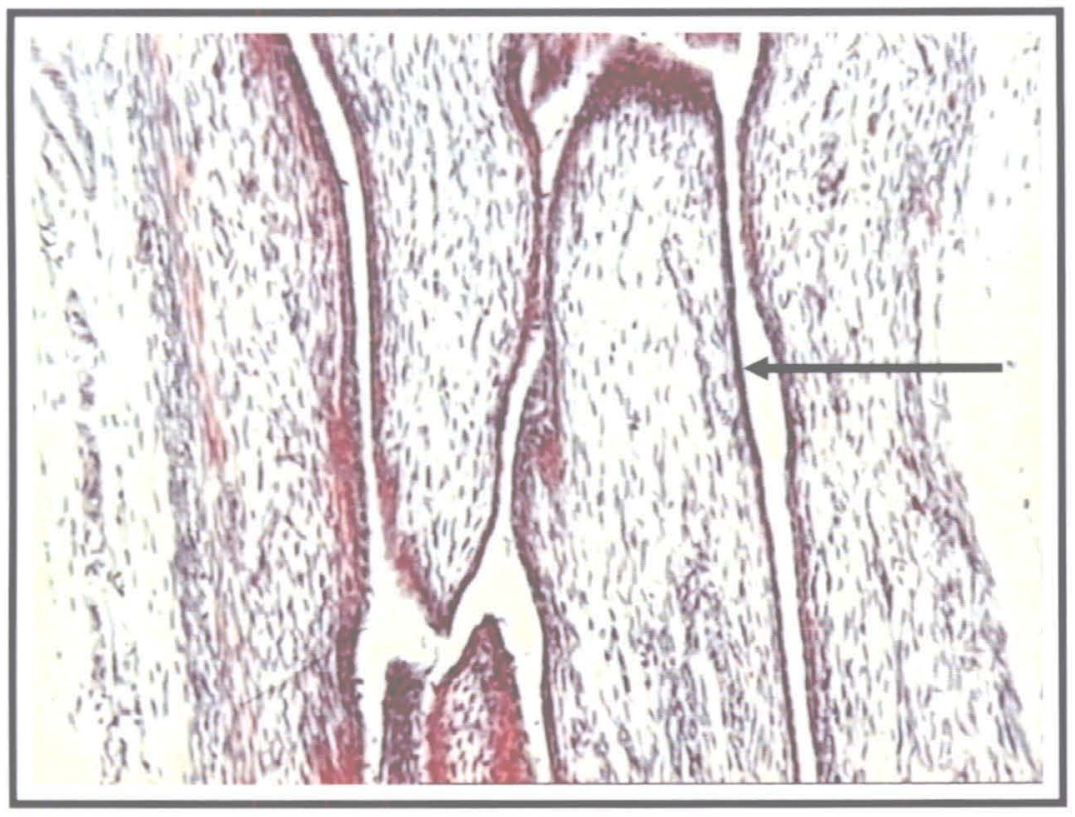

Figura 4. Animal do grupo Iso Low.

Ectocérvice revestida por uma fina camada de células escamosas basais e parabasais. HE x 100 . 


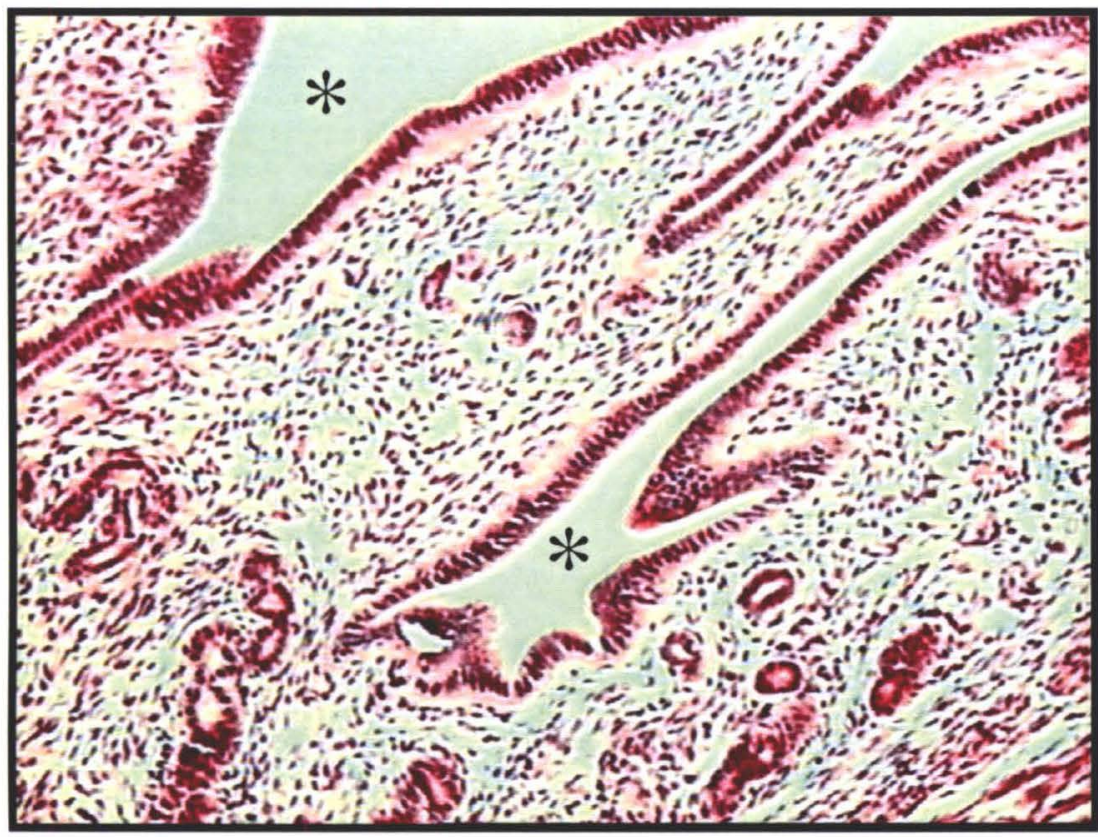

Figura 5. Animal do grupo Iso Low.

Endocérvice mostrando glândulas pouco dilatadas (*). HE x 100 .

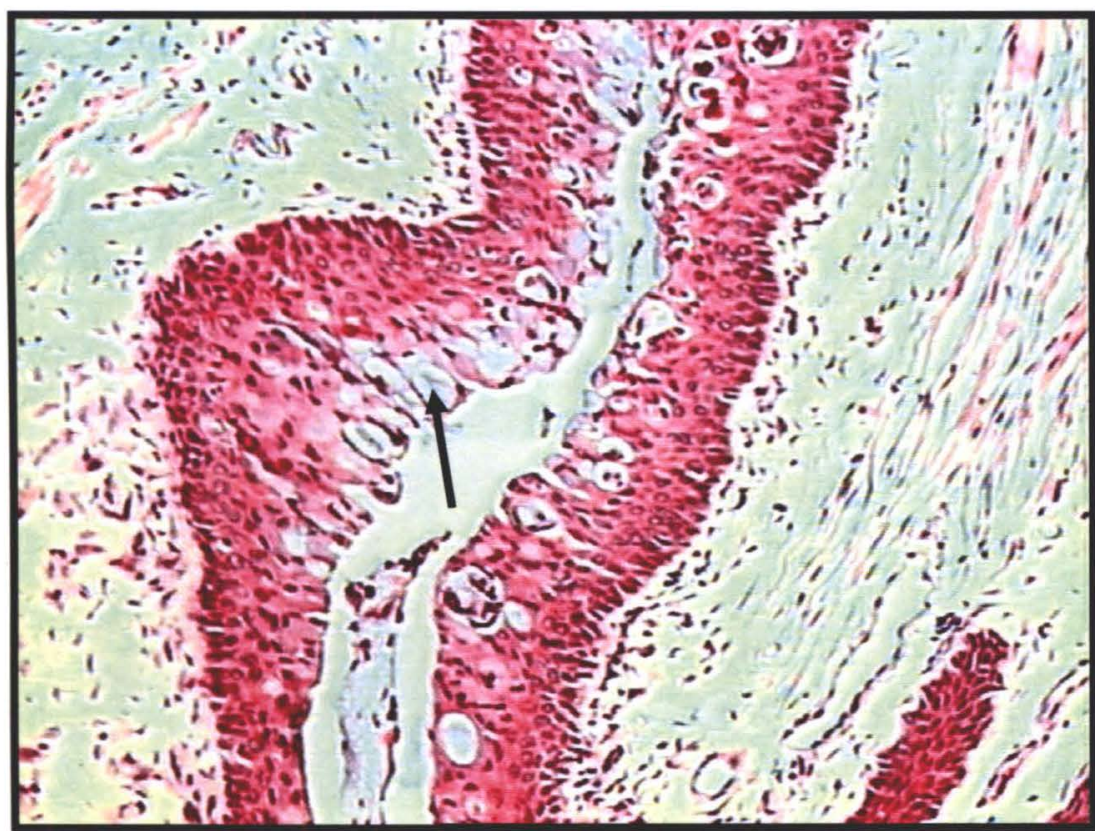

Figura 6. Animal do grupo Iso High.

Ectocérvice revestida por epitélio escamoso estratificado com espessura dentro dos limites da normalidade. Observa-se presença de células mucosas sobre o epitélio (seta). HE x 100. 


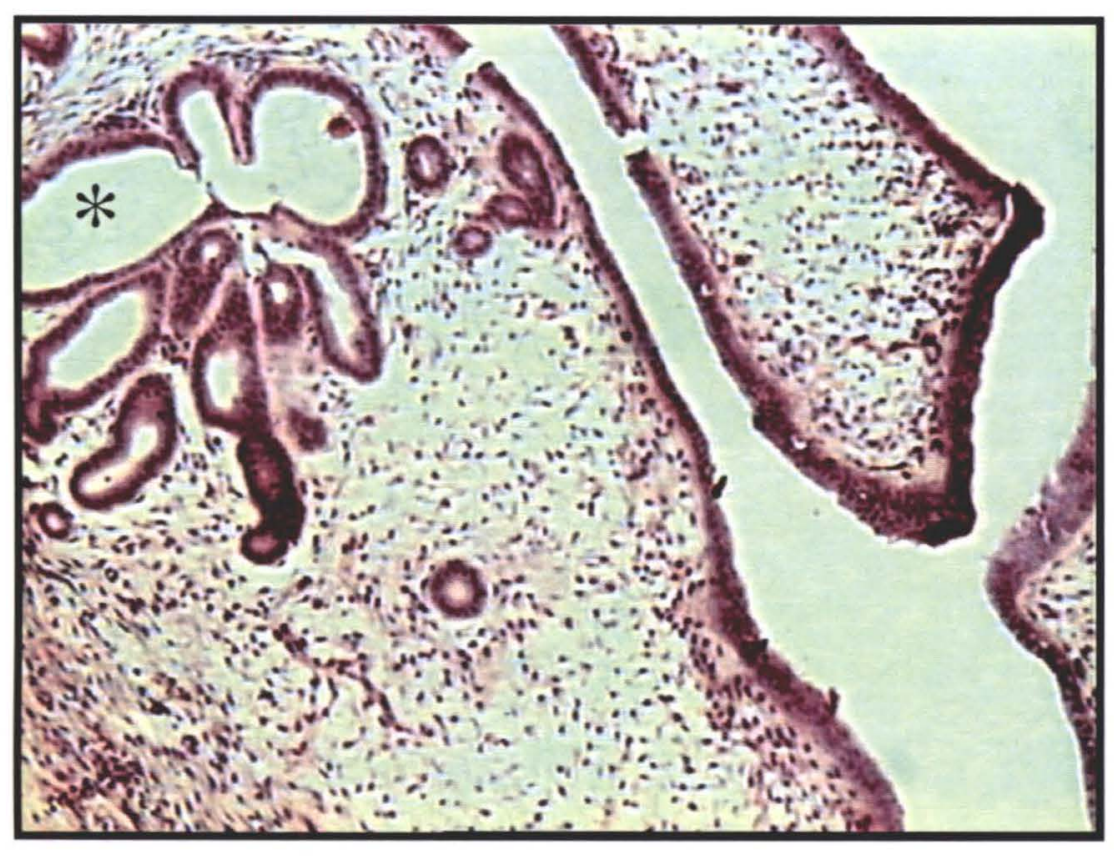

Figura 7. Animal do grupo Iso High.

Endocérvice mostrando glândulas dilatadas (*) e aumentadas em número. HE x 100.

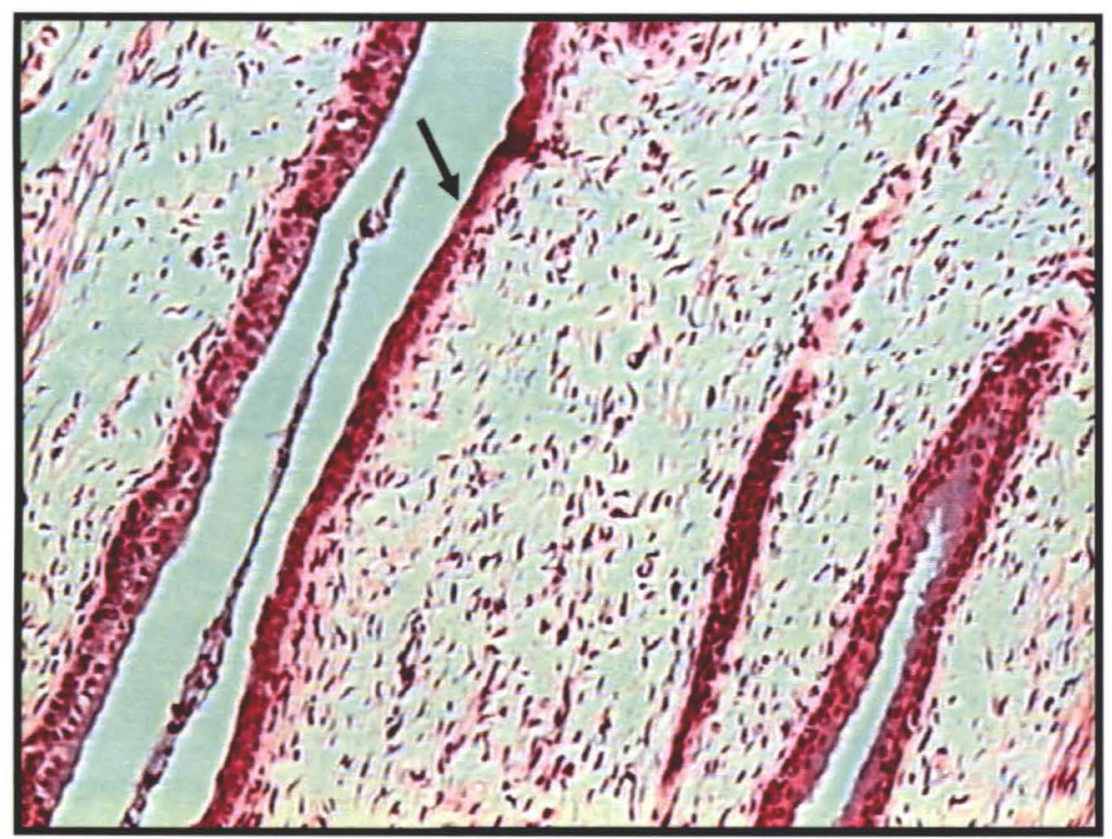

Figura 8. Animal do grupo Controle.

Etocérvice revestida por epitélio escamoso estratificado de espessura reduzida, constituído por células basais e parabasais (seta). HE x 100 . 


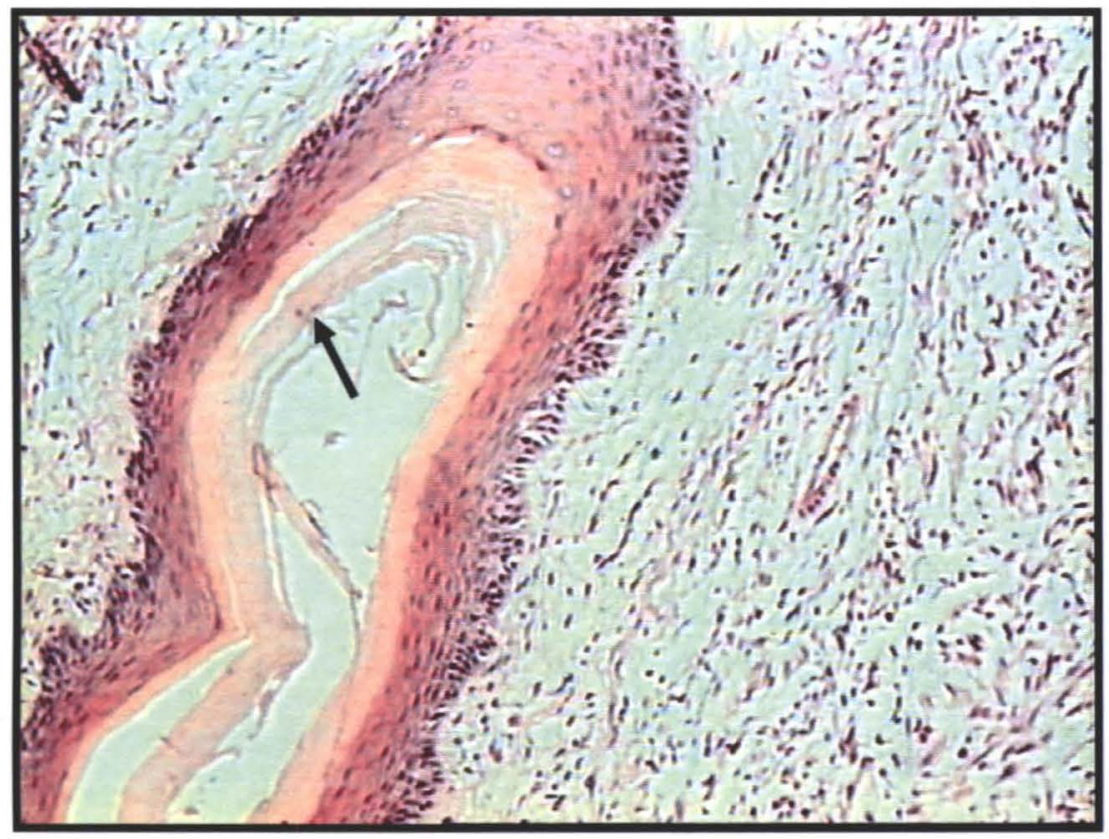

Figura 9. Animal intacto (não ooforectomizado).

Ectocérvice revestida por epitélio escamoso estratificado normal na sua arquitetura e espessura. Presença de camada de queratina (seta) e células queratinizadas. Evidente diferenciação entre as camadas basal $e$ superficial. HE x 100.

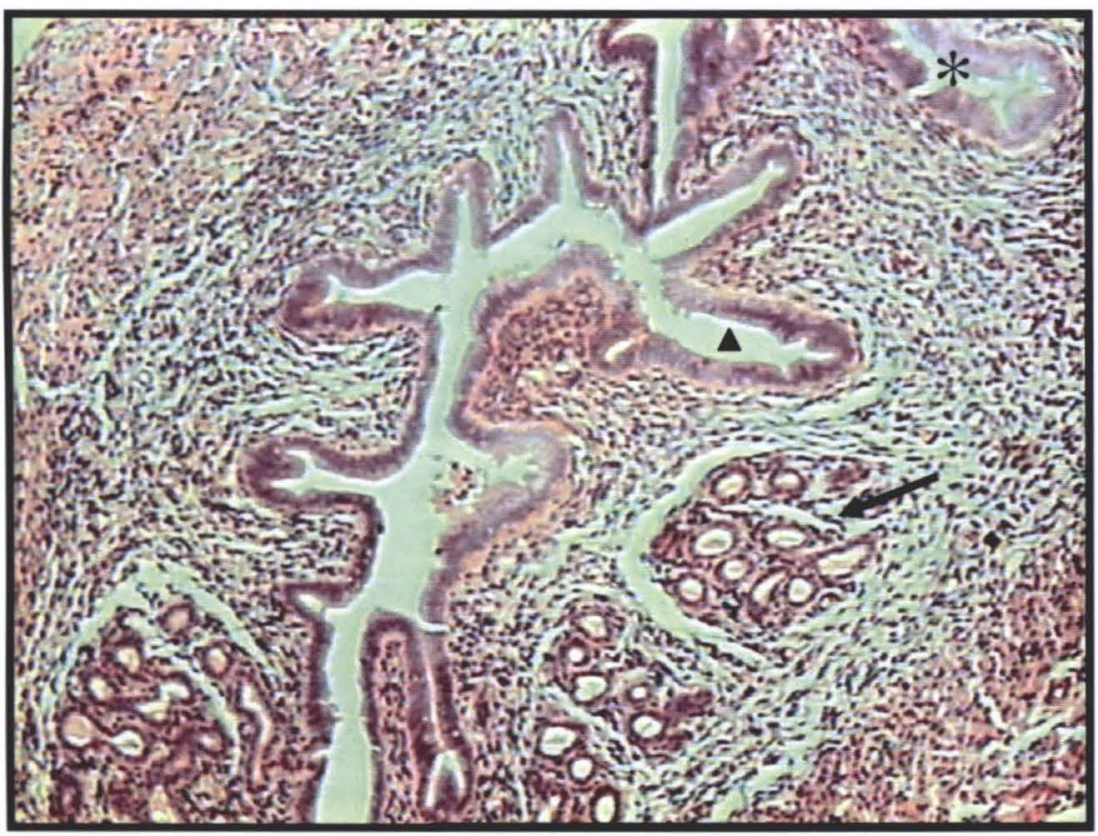

Figura 10. Animal intacto (não ooforectomizado).

Transição entre endocérvice e endométrio, mostrando endocérvice pouco glandular (cabeça de seta) e endométrio com glândulas pequenas e com secreção na sua luz (seta). Notar ectocérvice normal (*). HE x 100. 


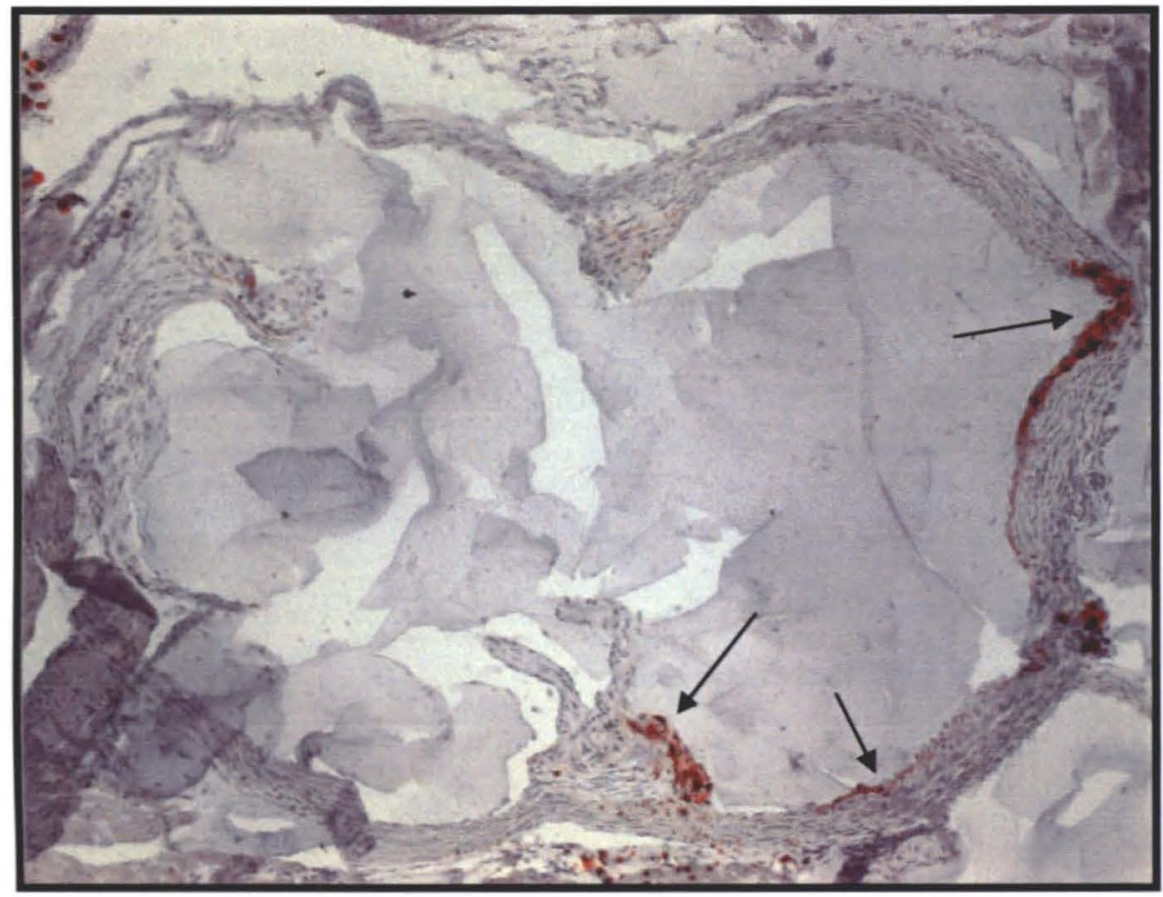

Figura 1. Animal do grupo EE. Área de depósito de gordura (seta). OR $\times 10$

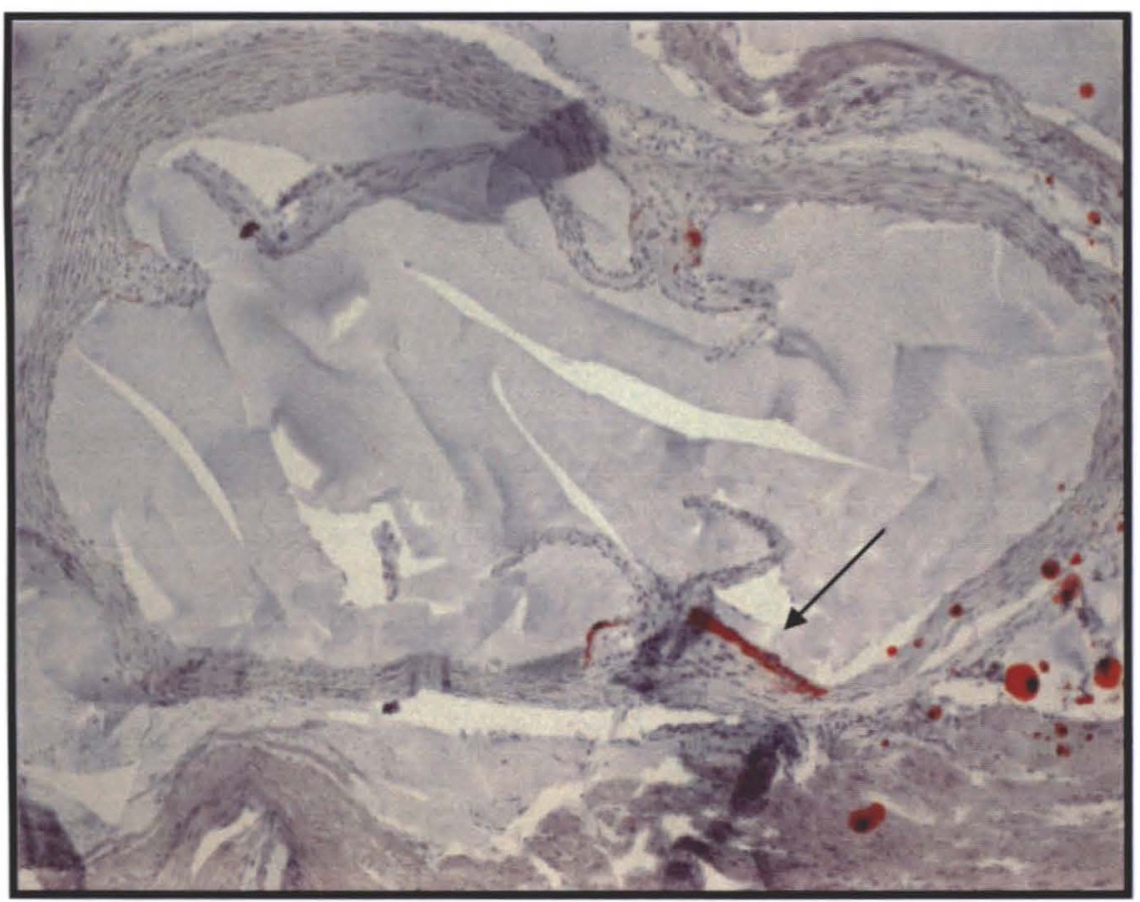

Figura 2. Animal do grupo Iso Low. Área de depósito de gordura (seta). OR $\times 10$ 


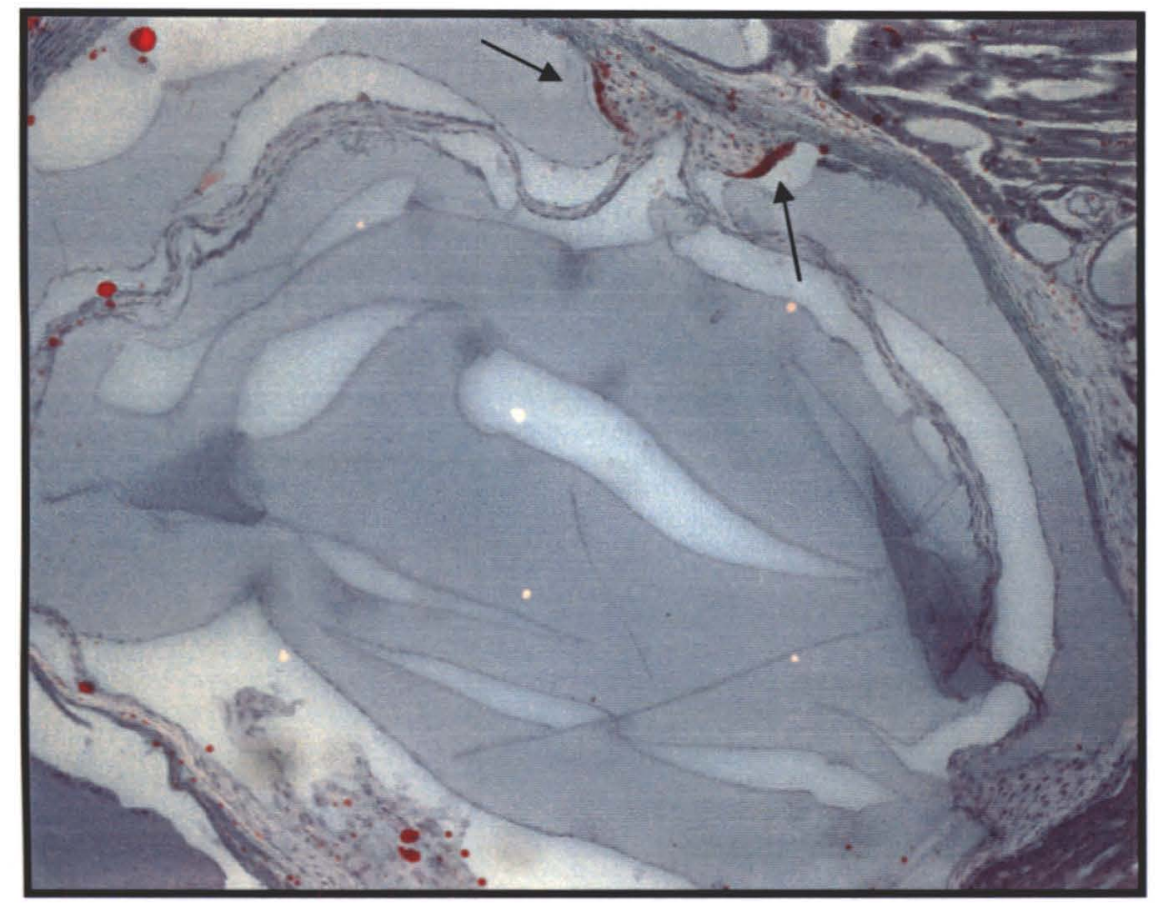

Figura 3. Animal do grupo Iso High. Área de depósito de gordura (seta). OR $\times 10$

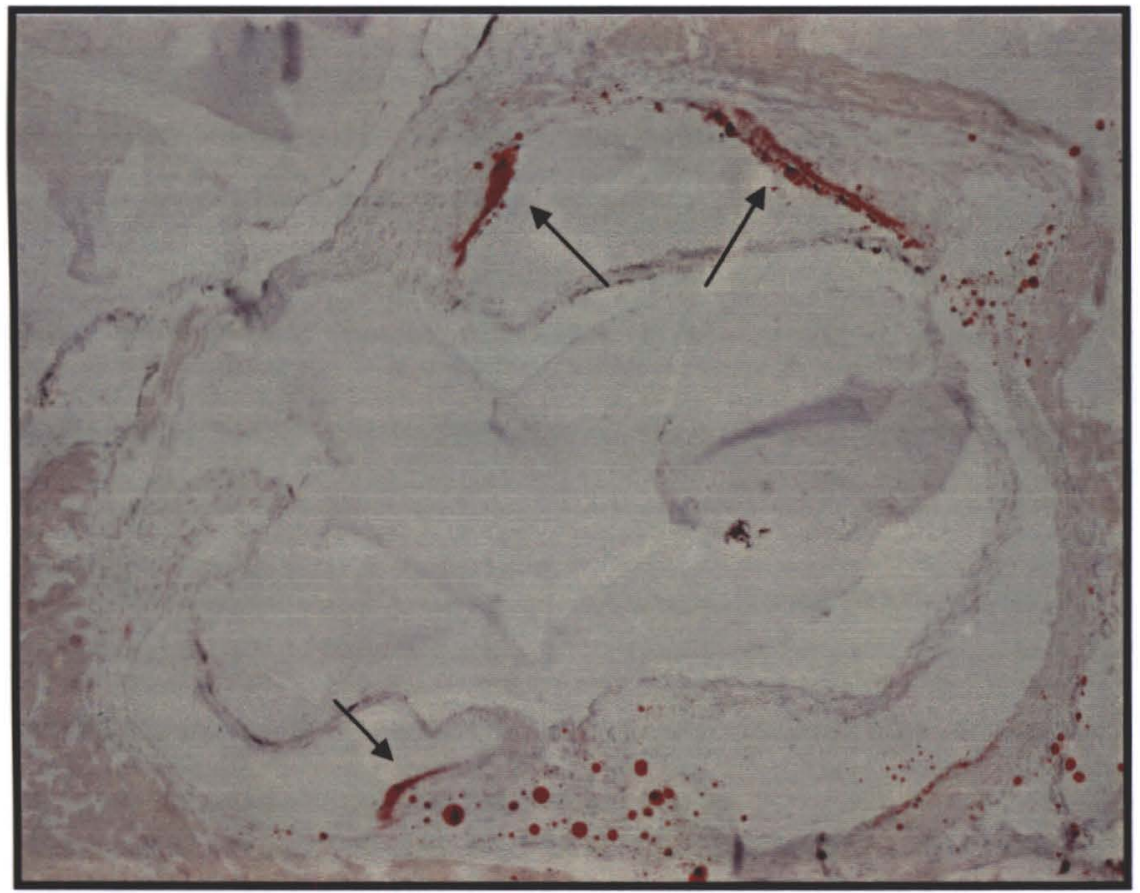

Figura 4. Animal controle. Área de depósito de gordura (seta). OR x 10 
Anexo 8 - Resumo de trabalhos com animais e aterosclerose experimental.

\begin{tabular}{|c|c|c|c|c|c|}
\hline $\begin{array}{l}\text { modelo } \\
\text { animal }\end{array}$ & EE $(\mu g / d)$ & \begin{tabular}{|l|} 
tempo de \\
duração \\
(semanas) \\
\end{tabular} & $\begin{array}{l}\text { lípides } \\
\text { plasmáticos }\end{array}$ & área de ateroslcerose & $\begin{array}{l}\text { referência } \\
\text { bibliográfica }\end{array}$ \\
\hline $\mathrm{ApoE}^{-/-}$ & 6 a 28 & 13 & $\downarrow$ CT e VLDL & $\downarrow 50 \%$ & $\begin{array}{l}\text { Bourassa et } \\
\text { al., } 1996\end{array}$ \\
\hline $\mathrm{ApoE}^{-1}$ & 0,17 a 8,3 & 8 & $\downarrow \mathrm{CT}$ & $\downarrow 30$ a $75 \%$ & $\begin{array}{l}\text { Elhage et al., } \\
1997\end{array}$ \\
\hline $\begin{array}{l}\mathrm{ApoE}^{-/-} \\
\mathrm{ER} \alpha^{-/ .}\end{array}$ & 6 & 13 & sem diferença & sem diferença & $\begin{array}{l}\text { Hodgin et al., } \\
2001\end{array}$ \\
\hline $\begin{array}{l}\text { CETP }^{+1-} \\
\text { LDLr }^{+/-}\end{array}$ & 6 & 9 & sem diferença & sem diferença & $\begin{array}{l}\text { Cazita et al., } \\
2003\end{array}$ \\
\hline ApoE-/- & 0,1 & 8 & $\downarrow \mathrm{CT}$ & $\downarrow 65 \%$ & $\begin{array}{l}\text { Shultz et al., } \\
2004\end{array}$ \\
\hline $\begin{array}{l}\mathrm{ApoE} \mathrm{E}^{-/-} \\
\mathrm{ER} \alpha^{-/}\end{array}$ & $\begin{array}{l}\text { ISO: } \\
34 \mathrm{mg} / 100 \mathrm{~g} \\
\text { dieta }\end{array}$ & 16 & sem diferença & $\begin{array}{l}\text { sem diferença } \\
\text { (conteúdo de } \\
\text { colesteril éster) }\end{array}$ & $\begin{array}{l}\text { Adams et al., } \\
2002 \mathrm{a}\end{array}$ \\
\hline ApoE-/- & $\begin{array}{l}\text { ISO: } \\
34 \mathrm{mg} / 100 \mathrm{~g} \\
\text { dieta }\end{array}$ & 16 & sem diferença & $\begin{array}{l}\text { sem diferença } \\
\text { (conteúdo de } \\
\text { colesteril éster) }\end{array}$ & $\begin{array}{l}\text { Adams et al., } \\
2002 \text { b }\end{array}$ \\
\hline LDL-/- & $\begin{array}{l}\text { ISO: } \\
28 \mathrm{mg} / 100 \mathrm{~g} \\
\text { dieta }\end{array}$ & 16 & $\downarrow \mathrm{CT}$ & $\downarrow 50 \%$ & $\begin{array}{l}\text { Adams et al., } \\
2004\end{array}$ \\
\hline macacas & $\begin{array}{l}\mathrm{CEE}(0,042 \\
\mathrm{mg} / \mathrm{kg} / \mathrm{d} \\
\mathrm{v} .0 .) ; \\
\mathrm{ISO}(8,6 \\
\mathrm{mg} / \mathrm{kg} / \mathrm{d})\end{array}$ & 145 & $\begin{array}{l}\text { CEE<controle; } \\
\text { ISO }<\text { controle; }\end{array}$ & $\begin{array}{l}\text { coronária: } \\
\mathrm{CEE}<\text { controle } \\
\mathrm{CEE}<\mathrm{ISO} \\
\text { carótidas: } \\
\mathrm{CEE}<\text { controle } \\
\text { ISO < controle }\end{array}$ & $\begin{array}{l}\text { Clarkson et } \\
\text { al., } 2001\end{array}$ \\
\hline
\end{tabular}

São citados trabalhos com camundongos fêmeas ooforectomizadas, ou outras espécies, quando citado, submetidas ao tratamento com $17 \beta$ etinil-estradiol ou com isoflavonas, ou ambos. A forma de administração do hormônio é por implante subcutâneo de pellet, ou outra, quando citado. Os lípides plasmáticos e a área de lesão aterosclerótica são em comparação aos respectivos grupos controle. Abreviaturas usadas na tabela: v.o.: via oral; $\mathrm{CEE}$ : estrógeno eqüino conjugado; EE: 17ßetinilestradiol; ISO: isoflavonas. 